\title{
Cerebral small-vessel disease : vascular risk factor profiles, clinical manifestations, and disease progression in stroke
}

Citation for published version (APA):

van Zagten, M. S. G. (1997). Cerebral small-vessel disease : vascular risk factor profiles, clinical manifestations, and disease progression in stroke. [Doctoral Thesis, Maastricht University]. Universiteit Maastricht. https://doi.org/10.26481/dis.19971219mz

Document status and date:

Published: 01/01/1997

DOI:

10.26481/dis.19971219mz

Document Version:

Publisher's PDF, also known as Version of record

Please check the document version of this publication:

- A submitted manuscript is the version of the article upon submission and before peer-review. There can be important differences between the submitted version and the official published version of record.

People interested in the research are advised to contact the author for the final version of the publication, or visit the DOI to the publisher's website.

- The final author version and the galley proof are versions of the publication after peer review.

- The final published version features the final layout of the paper including the volume, issue and page numbers.

Link to publication

\footnotetext{
General rights rights.

- You may freely distribute the URL identifying the publication in the public portal. please follow below link for the End User Agreement:

www.umlib.nl/taverne-license

Take down policy

If you believe that this document breaches copyright please contact us at:

repository@maastrichtuniversity.nl

providing details and we will investigate your claim.
}

Copyright and moral rights for the publications made accessible in the public portal are retained by the authors and/or other copyright owners and it is a condition of accessing publications that users recognise and abide by the legal requirements associated with these

- Users may download and print one copy of any publication from the public portal for the purpose of private study or research.

- You may not further distribute the material or use it for any profit-making activity or commercial gain

If the publication is distributed under the terms of Article 25fa of the Dutch Copyright Act, indicated by the "Taverne" license above, 


\section{Cerebral small-vessel disease}

Vascular risk factor profiles, clinical manifestations, and disease progression in stroke 
Cover: Anne-Marie Boogaarts

The publication of this thesis was financially supported by:

Eili Lilly Nederland, Roche Nederland, ASTA-Medica, Boehringer Ingelheim, Kalwijik Farma, Rhône-Poulenc Rorcr.

Cerebral small-vessel disease; vascular risk factor profiles, clinical manifostations, and disease prognession in stroke.

Marian van Zagten

Thesis Universiteit Mastricht

ISBN $90-9011130-1$

NUGT 742

(c) 1997, M.S.G. van Zagten, Mastricht, The Netherlands

All rights are reserved, whether the whole or part of the material is concerned. No part of this publication may be reproduced, stored in a retrieval system, or transmitted in any form or by any menns, electronic, mechanical, photocopyngh, recording or otherwise, without written permission from the copyright owner. 


\title{
Cerebral small-vessel disease
}

\section{Vascular risk factor profiles, clinical manifestations, and disease progression in stroke}

\author{
PROEFSCHRIFT
}

ter verkrijging van de graad van doctor aan de Uniwersiteit Mastricht, op gezag van de Rector Magnificus, Prof. Mr. M.J. Cohen volgens het besluit van het College wan Decanen, in het openbarar te verdedigen op vrijdag 19 december 1997 om 14.00 uur

door

Maria Sophia Gerarda van Zagten 


\section{Promotor}

Prof.dr. J. Troost

\section{Co-promotores}

Dr. J. Lodder

Dr. J. Boiten

\section{Beoordelingscommissie}

Prof.dr. P.W. de Leeuw (voorzitter)

Prof.dr. J.H.A. de Keyzer (Rijksuniversiteit Groningen)

Dr. B. Norrving (University Hospital Lund, Sweden)

Prof.dr. R.S. Reneman

Prof.dr. J.Th. Wilmink

This thesis was prepared at the Departinent of Neurology, University Hospital Maastricht, The Netherlands. 
... the input of the science-sausage-machine is neither money nor laboratory hardware, but human endeavour.

Yehuda Fried and Joseph Agassi

Paranoia: a study in diagnosis (1976) 


\section{Contents}

General introduction

1 Introduction

2 Different vascular risk factor profiles in primary intracerebral haemorrhage and lacunar stroke do not suggest similar type of underlying smallvessel disease

3 Significant progression of white matter lesions and small deep (lacunar) infarcts in stroke patients

4 Strong association between white matter lesions and multiple small deep infarcts suggests similar type of underlying small-vessel disease

5 Interobserver agreement in the assessment of cerebral atrophy on CT using bicaudate and Sylvian fissure ratios

6 Cerebral ventricular enlargement in stroke patients is not specifically associated with either small- or large-vessel disease

7 Gait disorder and parkinsonian signs in patients with stroke relate to small deep infarcts and white matter lesions

8 General discussion $\quad 93$

$\begin{array}{ll}\text { Summary } & 99\end{array}$

$\begin{array}{lr}\text { Samenvatting } & 103\end{array}$

$\begin{array}{lr}\text { References } & 109\end{array}$

$\begin{array}{lr}\text { Publications } & 123\end{array}$

Dankwoord

Curriculum Vitae 


\section{General introduction}

Stroke constitutes an important health care issue. Its prevalence is high, especially in the elderly: $3.5 \%$ in men older than 55 years and $1.9 \%$ in women [119]. Furthermore, stroke poses an ever increasing financial burden on society: in The Netherlands lifetime health care costs for stroke patients were estimated to be 1870 million Dutch guilders [13], and the total yearly costs of stroke (medical and productivity losses) amount to 2500 million Dutch guilders [48]. Apart from the primary morbidity of stroke, its long-term consequences may lead to substantial additional morbidity, e.g., vascular dementia $[77,83,85,175,177]$, and vascular parkinsonism $[40,195,196]$.

Up to now stroke treatment focused mainly on secondary prevention. However, the results achieved are moderate. Antiplatelet therapy results in an absolute risk reduction in non-fatal stroke of $2 \%$ ( $8.2 \%$ in treated patients, $10.2 \%$ in controls) in patients with a prior stroke or transient ischaemic attack at 33 months, i.e., a relative risk reduction of $23 \%$ [2]. Combination of aspirin with dipyridamole may have additional benefit [43]. The North American Carotid Surgery Trial [143] found an absolute risk reduction in ipsilateral stroke of $17 \%$ at 2 years ( $9 \%$ in surgical patients and $26 \%$ in controls), i.e., a relative risk reduction of $65 \%$, in patients with a minor stroke or transient ischaemic attack with a symptomatic carotid stenosis of 70-99\%. The European Carotid Surgery Trial [47] found a somewhat smaller, but still significant benefit of surgery: the absolute risk reduction was $6.6 \%$ at 3 years (10.2\% in surgical patients and $16.8 \%$ in controls), i.e., a relative risk reduction of $39 \%$. Anticoagulation-therapy in non-rheumatic atrial fibrillation in ischnemic stroke patients results in an absolute risk reduction of stroke of $8 \%$ per year ( $4 \%$ in treated patients and $12 \%$ in controls), i.e., a relative risk reduction of $67 \%$ per year [45]. Although these results of carotid surgery and anticoagulation-therapy in non-rheumatic atrial fibrillation are substantial, these therapies are of use in only a small proportion of palients, with a certain stroke subtype.

Stroke is not a homogeneous disease-entity. Stroke may be divided into cerebral haemorrhage and infarction. These two types can be further divided on the basis of different underlying stroke mechanisms. Cerelbral haemorrhage may be secondary, e.g., to use of anticoagulants, or primary as a result of small-vessel disease. A brain infarct may result from small-vessel disease, large-vessel disease, or cardiac embolism. Risk factor profiles, symptoms and signs, pathogenesis, therapy, prognosis, and long-term sequelae differ among these stroke subtypes. The results of stroke prevention by carotid surgery and anticoagulants in non-rheumatic atrial fibrillation show that prevention in appropriate subgroups may 
be highly effective. So, effective prevention of stroke depends on the pathogenesis and risk factor profiles in stroke subgroups. Knowledge of what causes a stroke in individual patients may allow intervention to be tailored more rationally.

In this study we chose to investigate several aspects of lesions presumably caused by cerebral small-vessel disease, such as small deep (lacunar) infarcts, white matter lesions (WMLs), and primary deep intracerebral haemorrhage. We aimed to investigate whether these heterogeneous lesions are homogeneous as to the type of underlying vascular disease (presumably cerebral small-vessel disease). Furthermore, possible long-term consequences of cerebral small-vessel disease were investigated, such as cerebral atrophy and vascular parkinsonism.

The specific study aims were:

1. To investigate whether primary deep intracerebral haemorrhage and small deep (lacunar) infarcts have a similar type of underlying small-vessel vasculopathy as reflected by their vascular risk factor profiles. (Chapter 2)

2. (I) To test the hypothesis that WMLs are associated with small deep (lacunar) infarcts as both are supposedly caused by small-vessel pathology, and (II) to study whether WMLs and small deep infarcts progress over time. (Chapter 3)

3. To study (I) the incidence of WMLs in first-ever ischaemic stroke patients, and (II) WMLs in relationship with vascular risk factors, symptomatic and silent infarcts, to test the hypothesis that WMLs are especially associated with multiple, usually silent small deep infarcts. (Chapter 4 )

4. To test whether cerebral atrophy in stroke patients is related to presence of WMLs, stroke subtype and/or multiple brain infarcts. (Chapter 5 and 6)

5. To study (I) the prevalence of parkinsonian signs in ischaemic stroke patients, and (II) whether such signs are associated with small deep (lacunar) infarcts, WMLs, and/or territorial infarets, to test the hypothesis that vascular parkinsonism results mainly from cerebral small-vessel disease. (Chapter 7 ) 
1

Introduction 


\section{Stroke subtypes}

Stroke is a general term for several types of vascular injuries to the brain. Firstly, stroke can be divided into cerebral haemorrhage ( $\pm 15 \%)$ and cerebral infarction $( \pm 85 \%)$ [189]. Cerebral haemorrhage is either intracerebral or subarachnoideal. Introcerebral haemorthage may be primary, or secondary, such as due to rupture of vascular malformations or use of anticoagulants. Primary intracerebral haemorrhage is predominantly located in the deep regions of the brain (69-88\%), i.e., in the basal ganglia and thalamus, and furthermore in the brainstem, and less frequently in the cerebral lobes and in the cerebellum $[33,53,146]$. Hypertension is the only known risk factor for primary intracerebral haemorrhage, with a prevalence of about $60 \%[33,53,146,189]$. The deep regions of the brain are supplied by small deep penetrating arteries and arterioles, such as the lenticulostriate, thalamoperforating and anterior choroidal arteries [67] (Figure 1.1). These small arteries are branches of the large cerebral arteries (i.e., the anterior, middle and posterior cerebral artery). Functionally, the small deep perforating arteries are endarteries, although anastomoses may exist $[69,123,157]$. Pathologic studies showed that arteriolosclerosis is the underlying vasculopathy in primary intracerebral haemorrhage. Arteriolosclerosis probably leads to disruption of muscle and elastic elements in the arterial wall by deposition of lipid-rich hyaline material subintimal. Subsequently, this may lead to bulging of arterial walls ('so-called Charcot-Bouchard microaneurysms) [33, 146].

Cerebral infarction is categorized according to involved vascular territory in posterior circulation infarcts $(24 \%)$, anterior circulation infarcts (51\%) and small deep (lacunar) infarcts (25\%) [189]. Another classification using location, infarct size, clinical features, and underlying stroke mechanism, is in territorial and small deep infarcts. The cause of cerebral infarction is in $50 \%$ atherothromboembolism, in $20 \%$ embolism from the heart, in $25 \%$ intracranial small-vessel disease, and in $5 \%$ rarities such as arterial dissection, vasculitis, etc. [189]. Territorial infarcts (Figure 1.2) usually correspond with main stem or large branch occlusion of one of the major cerebral arteries, and extend into the cerebral cortex. Clinically they cam be diagnosed by signs of cortical dysfunction, e.g., dysphasia or neglect. There is substantial necropsy and radiological support that such infarcts result from occlusion of the proximal stem of the middle or anterior cerebral artery, either by ambolism or by spread of thrombus into the vessel from a more proximal occlusion. Carotid stenosis as a result of atherosclerosis may be the cause of territorial infarets either by being a source of embolism, or by spread of thrombus into the middle or anterior cerebral artery $[9,17,107,142]$. Another frequent source of cerebral emboli is the heart. For instance dysrythmias, e.g., atrial fibrillation, and prosthetic heart valves, may lead to large numbers of emboli $[9,17,62,114,142,185]$.

Small deep (lacunar) infarcts are small infarcts in the basal ganglia, thalamus, internal capsule, or the pons (Frgure 1.2). Compared with those witl a territorial infarct, patients with a small deep infarct have a higher survival rate and less disability $[19,107]$. 


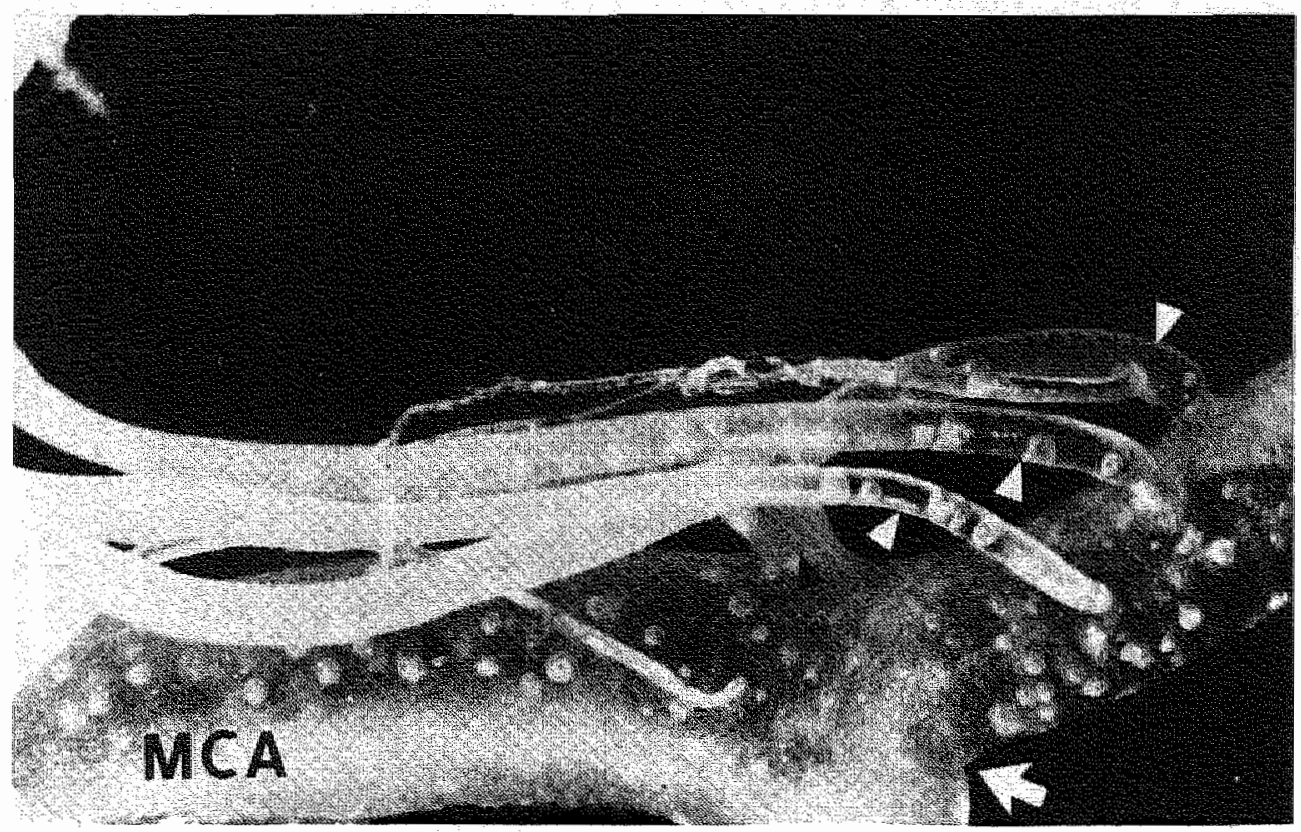

Figure 1.1: Plastic cast (magnification 11x) showing perforating branches (black and white arrowheads) arising from the middle cerebral artery (MCA). White arrow indicates division of MCA. (From Marinkovic et: al. [124].)

Hypertension is the most important vascular risk factor associated with small deep infarcts [58, 114, 127]. However, hypertension is not a stronger risk factor for small deep than for other cerebral infarcts. Just like primary intracerebral haemorrhage, small deep (lacumar) infarcts are thought to be caused by a disease of the small penetrating arterles and arterioles in the deep regions of the brain [59]. Pathological evictence points at two distinct small-vessel diseases. Arteriolosclerosis may be the cause of multiple, usually silent small deep infarcts, whereas the somewhat larger, symptomatic ones are caused by microatheromatosis $[34,58]$. On clinical grounds one might argue that two distinct small. deep infarct entities exist, reflecting these two types of small-vessel disease. Recenty, Boiten and Lodder [20] found that multiple, usually sillent small deep infarcts differed in location (more often in the anterior limb of the internal capsule and in the caudate nuclous, less often in the posterior limb of the intemal capsule), involved vascular territory (norc often in the lateral and medial striate arteries territory, less often in the anterior choroidal artery territory), and volume (smaller) from symptomatic lacunar infarcts. Hypertension was more frequent in patients with silent small deep infarcts (71\%), than in those with a single symptomatic lacunar stroke (43\%). These findings were confirmed by Mast et al. [127], who found multiple small deep infarcts, but not single ones, to be associated with 

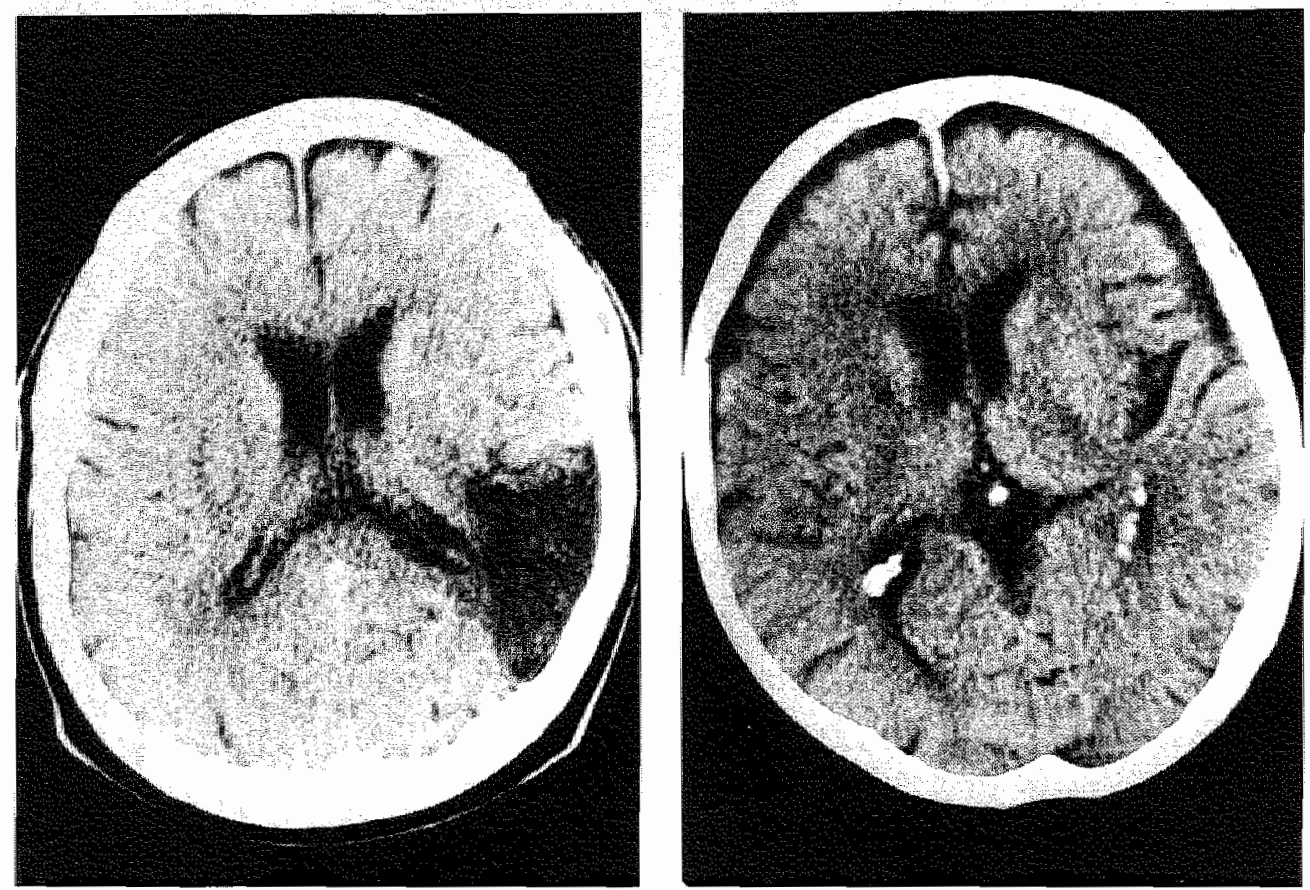

Figure 1.2: Computed tomographic scans of the two subtypes of cerebral infarction: (left) a territorial infarct in the posterior part of the area supplied by the left middle cerebral artery. (right) a small deep infarct in the anterior limb of the right internal capsule.

hypertension and diabetes mellitus. Furthermore, cerebral blood flow in the cerebral cortex wass found to be significantly lower in patients with multiple small deep infarcts than in those with a single small deep infarct [133]. These studies suggest that there are indeed two distimct entities: multiple (silent) small deep infarcts probably caused by arteriolosclerosis, and the (larger) symptomatic ones due to microatheromatosis. Moreover, hypertension is probably a more important risk factor in arteriolosclerosis than in microatheromatosis.

Another presumably ischaemic type of cerebral lesion is leukoaraiosis, also termed white matter lesions (WMLL) (Figure 1.93). Hachinski et al. [78] introduced the term leukoaraiosis to describe periventricular diffuse white matter hypodensities on computed tomography (CI). WMLs were defined as focal or diffuse hypodensities in the periventricular or deep white matter (centrum semiovale), not involving the cortex, and with ill-defined margins to distinguish them from infarction [168]. WMLs were originally attributed to subcortical arterioscherotic encephalopathy or Binswanger's disease $[36,90,100,117,118,1561$, but were also described in the general population $[30,49,52,113,193]$, in patients with 
hypertension [186], in stroke patients [81, 87,91,96, 99, and in patients with dementia $[12,31,32,105,111,154,169]$. Previous studies found WMLs to be related to varions vascular risk factors: higher age $[4,30,32,37,81,87,96,113,122,171,193]$, hypertension $[4,30,32,112,122]$, use of diuretics [32], history of heart disease [30, 113], diabetes mellitus [193], and hypoxia [37]. WMLs have been associated with mental impaiment and dementia $[72,94,100,169,182]$, and with multiple neurological deficits, such as gait and balance disorders, psendobulbar state, and incontinence $[6,8,12,94,126,149,168,169$, $179,196]$. Although sometimes a mixture of pathologic changes are found in WMLs, many authors hold arteriolosclerosis as the primary factor in WMLs $[3,7,28,31,162,187]$. However, contrary to primary intracerebral haemorrhage and small deep infarcts, WMLs are not located in the vascular territories of the small deep penetrating arteries and arterioles. The centrum semiovale, where WMLs are found, is supplied by long medullary arteries arising from the leptomeningeal plexus, which in turn arises from cerebral surface branches of the anterior, middle, and posterior cerebral arteries $[64,140]$. In the white matter the capillary density is smaller than in the basal ganglia [135]. Anastomotic channels between these medullary arteries in the cortex and white matter may exist [140]"

\section{Cerebral small-vessel disease}

So, cerebral small-vessel disease may express itself in different ways: (1) as primary deep intracerebral haemorrhage, (2) as small deep (lacunar) infarct, (3) as WMLs (Table 1.1). In primary intracerebral haemorrhage, multiple silent small deep infarcts and WMLs nenropathologic studies, which are strikingly scarce, have found arteriolosclerosis as the underlying vasculopathy $[31,53,60,64,66,187]$. Arteriolosclerosis consists of patchy deposition of hyline and lipid material, often beneath the endothelium, but sometimes more peripherally: the hyaline change gradually extends to involve the whole circumference, and when severe it replaces the normal structures of the wall apart from the endothelium, resulting in considerable narrowing of the arteriolar lumen [1]. Hyaline is a descriptive term, and is defined as any material that shows a reddish, homogenous appearance when stained with haematoxylin and eosin [194]. The nature of the arteriolosclerosis is not: fully understood: initially, the hyaline material resembles fibrin in its staining properties, but later it stains like collagen [194]. Many different terms have been used in the past to describe this small.vessel disease, e.g., Jipohyalinosis, fibrohyalinosis, and arteriolar hyalinosis [194]. In this thesis we chose to use "arteriolosclerosis" to describe this small-vessel disease, becase it is a general term which encompasses all pathological findings in this vasculopathy, such as lipid and fibrin depositions. Arteriolosclerosis is found in hypertensive subjects and patients with diabetes mellitus, but is also seen especially in old age. Besides in the brain, it is found in the kidneys and in several other internal organs.

Apart from arteriolosclerosis, small deep infarcts may also be caused by microatheromatosis, in which a microatheroma occludes the small artery [34, 58]. The lesions of 

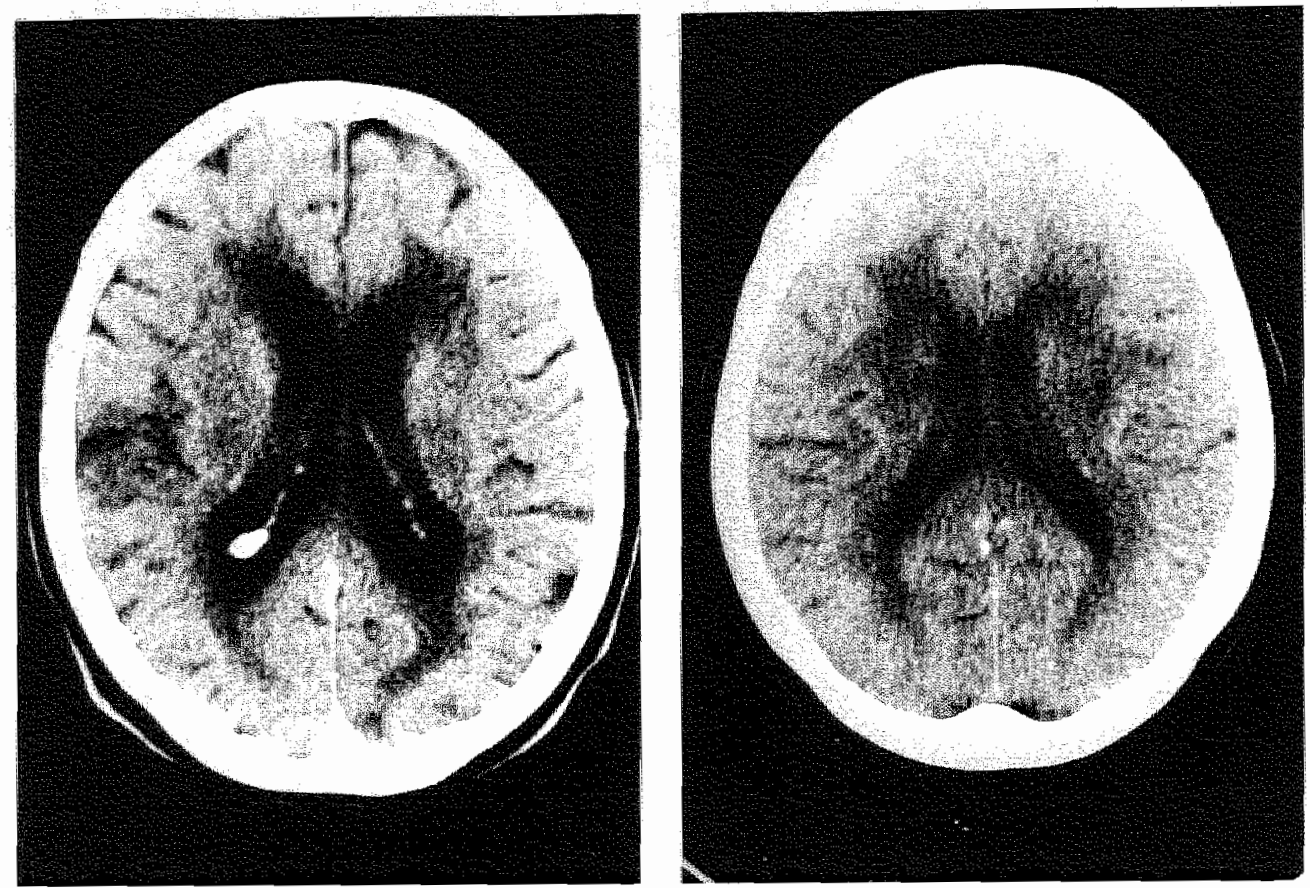

Figure 1.3: Computed tomographic scans of different sites of white matter lesions: (left) around the frontal and occipital horns, (right) around the frontal and occipital horns and in the centrum semiovale.

atheroma consist of patches ("plaques") of intimal thickening of the arterial walls, due mainly to deposition of lipids and formation of fibrous tissue [1]. This may result in progressive narrowing of the lumen or sudden ocelusion by the formation of a thrombus on an atheromatous plaque. In sparse pathologic reports $[34,58]$ three possible sites of microatheromatosis have been described leading to small deep intarcts. Finstly, an atheromatous plaque in a large cerebral artery may obstruct the orifice of a deep perforating branch. Secondly, a placue in a large cerebral artery may extend into a deep perforating branch. Furthernore, a microatheroma may originate in the orifice of a deep perforating branch. Risk factors for atheromatous changes of blood vessels are higher age, male gender, hypertension, diabetes mellitus, hyperlipidaemia, high plasma fibrinogen level and cigarette smoking [189]. 
Table 1.1: Affected arteries and arterioles in all types of lesions probably caused by the two types cerebral small-vessel disease.

\begin{tabular}{ccc}
\hline Type of lesion & Type of small-vessel disease & Affected arteries/arterioles \\
\hline $\begin{array}{c}\text { Small deep infarcts: } \\
\text { single symptomatic }\end{array}$ & microatheromatosis & small deep penetrating \\
multiple usually silent & arteriolosclerosis & small deep penetrating \\
Primary intracerebral haemorrhage & arteriolosclerosis & small deep penetrating \\
White matter lesions & arteriolosclerosis & long medullary \\
\hline
\end{tabular}

\section{Cerebral small-vessel disease and hypertension}

Primary intracerebral haemorrhage, small deep (lacunar) infarcts, and WMLs are all associated with hypertension $[4,30,32,33,53,58,112,122,146,151]$. However, the association between hypertension and WMLs was predominantily established in population-based studies $[30,112,122]$, whereas in a stroke population this association could not be confirmed [96]. It is unclear why a substantial number of primary intracerebral haemorrhage as well as lacunar stroke patients are not hypertensive $[11,17,33,35,114,134]$. So, although primary intracerebral haemorrhage, small deep infarct and WMLs all seem to result from small-vessel disease, the contribution of hypertension to the pathogenesis of each of these lesions is not clear and their vascular risk factor profiles differ.

\section{Co-existence of the various clinical manifestations of small-vessel disease}

Regarding their assumed common pathogenesis, co-existence of primary intracerebral haemorrhage, small deep inlarct and/or WMLs might be expected in patients. Indeed, WMIs are often found in lacunar stroke $[32,87,193]$ and in primary intracerebral haemorrhage patients [87]. Recurrent stroke following lacunar stroke is mostly ischaemic [19, 84], and in a minority haemorrhagic. Recently, intracerebral haemorrhage was found to be more frequent following lacunar stroke, than following territorial stroke [22]. Whether paticnts with a primary intracerebral haemorrhage often have multiple (silent) small deep infarcts has not been studied. If primary intracerebral haemornage was associated with multiple small deep infarcts, this would be yet another argument in favour of the concept thet multiple, usually silent small deep infarcts are due to arteriolosclerosis.

\section{Two distinct types of small-vessel disease}

As described above, pathological evidence of two different types of vasculoputhy underlying small deep infarets (arteriolosclerosis in multiple, usually silent smail deep inlarcts and microatheromatosis in the larger, symptomatic ones), is scarce. Due to the low case fatality rate in patients with lacunar stroke, pathologic data are difficult to collect. Multiple small deep infarcts, WMLs, and larger symptomatic small deep infarcts may have diffrent risk 
factor profiles $[20,127]$. Therefore, comparing the frequency of several vascular risk factors between patients with these different lesions may, although indirectly, point at the nature of the underlying small-vessel disease. Because more pathological studies have been done in prinary intracerebral haemorhage patients, arteriolosclerosis underlying this type of stroke is well established. Therefore, comparing vascular risk factor profiles in lacunar stroke and primary intracerebral haemorrhage patients could produce indirect clues as to similarity or difference in vascular pathology. Knowledge of the pathogenesis and risk factor profiles of all lesions caused by cerebral small-vessel disease could be of benefit in the prevention of these lesions, e.g., by more diligent treatment of the risk factors, and aid in the prevention of long-term sequelae.

\section{Long-term sequelae of cerebral small-vessel disease}

Apart from immediate physical disability, stroke may have long-term consequences such as cognitive decline, psychiatric sequelae (e.g., depression), post-stroke epilepsy, and parkinsonism. Such long-term stroke consequences may relate not only to the degree of cerebral tissue loss due to the symptomatic vascular lesion, but also to generalised tissue loss manifested as cerebral atrophy. Some found cerebral atrophy related to symptomatic stroke $[1.22,147]$, and to multiple cerebral infarcts on neuroimaging [98]. Cerebral atrophy may be related to cognitive impairment $[29,71,98,115,150,176]$. In stroke patients cerebral atrophy could also relate to the type of presumed vasculopathy underlying the stroke, such as small- or large-vessel disease, or cardiac embolism, but this has not been investigated so far.

Another possible long-term consequence of stroke may be the development of parkinsonian features. The concept of vascular parkinsonism is still a matter of debate. Neuroimaging studies in sellected parkinsonian patients found vascular lesions, mainly small deep infarcts and WMLs, to be related to certain parkinsonian features, especially lower body parkinsonism [61], Lack of resting tremor [88], marked gait difficulty [8, 126, 168], and L-elopa unresponsiveness [61]. However, in stroke patients vascular parkinsonism has hardly been investigated. If one could show that the proposed clinical signs of vascular parkinsonism would be related to (an increase of) especially small deep infarcts, WMLs, or both, this would strengthen the concept of vascular parkinsonism. Studying parkinsonism in stroke patients, e.g., the incidence of parkinsonian signs in stroke patients, and specific contributing factors to the development of these signs, could be relevant when aiming to improve functional outcome in stroke survivors. Furthermore, recognizing a vascular cause of parkinsonian features may influence the choice of therapy in parkinsonian patients. 
Different vascular risk factor profiles in primary intracerebral haemorrhage and lacunar stroke do suggest similar type of underlying small-vessel dis

Adapted from:

Van Zagten M, Lodder J, Franke C, Heuts-Van Raak L, Claassens C, Kessels F. Di vascular risk factor profiles in primary intracerebral haemorrhage and small deep in do not suggest similar types of underlying small vessel disease. Cerebrovasc Dis 1994; 124. 


\section{Abstract}

Objectives: To investigate vascular risk factor profiles in patients with primary intracerebral hamorrhage (PICH), lacunar, or territorial stroke, assuming that such profles may be indicative of the nature of the underlying vasculopathy.

Design: Surwey comparing vascular risk factors of prospectively registered stroke patients.

Setting: Primary and referral care centres.

Patients: Eighty-three patients with a supratentorial PICH, 241 with a lacunar, and 430 with a territorial stroke were registered.

Results: Multivariate logistic regression analysis showed that a history of ischaemic heart. disease and diabetes mellitus were less strongly associated with PICH than with ischaemic stroke of either type. Hypertension did not emerge as an independent variable associated with stroke subtype.

Conclusions: These differences in vascular risk factors do not support the idea of a similar nature of the underlying small-vessel disease in PICH and the majority of lacunar strokes. 


\section{Introduction}

Small deep, often called "lacunar" infarcts usually result from local obstruction of a small penetrating artery [11]. At autopsy on a limited number of cases pisher found smallvessel atheromatosis in symptomatic small deep infarcts, and arteriolosclerosis in cases with multiple, mostly silent small deep infarcts [58]. A stroke subtype that also occurs as a result of small penetrating artery pathology is primary intracerebral haemorthage (PICH), in which arteriolosclerosis is the most prevalent vasculopathy [53, 60]. Differences in type of underlying small-vessel pathology between PICH, and lacunar stroke may be reflected by differences in vascular risk factor profile. Knowledge about the nature of the small-vessel affliction in small deep infarcts is limited. Therefore, comparing the frequency of several vascular risk factors between patients with these different stroke subtypes may, although indirectly, provide information about the nature of the small-vessel disease in lacunar stroke; if vascular risk factor profiles in patients with lacunar stroke and PICH would be similar, arteriolosclerosis might be the most prevalent vasculopathy in lacunar stroke as it is in PICH.

\section{Patients and methods}

Patients with a supratentorially located PICH in the region of the basal ganglia were prospectively registered at the De Wever Hospital Heerlen and the University Hospital Utrecht. All patients, admitted or visiting the out-patient clinic, with a first-ever supratentorial brain infarct with symptoms lasting longer than 24 hours were registered in a prospective registry at the Uniwersity Hospital Maastricht. Routine inwestigations included standard blood tests, electrocardiogram, chest X-ray (in 60\% of PICH), CT scan of the brain, and noninvasive carotid studies in the infarct patients. Echocardiography, 24-hour" ECG monitoring, and cerebral angiography were done in selected cases.

\section{Definitions}

The following wascular risk factors were recorded: age, gender, hypertension (known hypertension, or at least 2 separate blood pressure recordings of higher than $160 / 90 \mathrm{~mm} \mathrm{Hg}$ before or at least 1 week after stroke), diabetes mellitus (known diabetes mellitus, or fasting serumglucose higher than $7 \mathrm{mmol} / \mathrm{l}$, or a postprandial serumglucose higher than $11 \mathrm{mmol} / \mathrm{l}$, both on at least 2 separate occasions), hypercholesterolemia (known hyporcholesterolemia, or serumcholesterol higher than $6.4 \mathrm{mmol} / 1$ ), history of ischaemic: heart disease (myocardial infarction, angina pectoris), cardiac source of embolism (atrial fibrillaw tion, mitral stenosis, prosthetic aortic or mitral valve, recent myocardial infarction (within 6 weeks preceding stroke), endocarditis, cardiomyopathy, left wentricular aneurysm, intraventricular thrombus), and significant (more than $50 \%$ ) carotid stenosis ipsilaterall to the 
symptomatic stroke.

Primary intracerebrat haemormage was defined as a primary supratentorially located haemorthage in the region of the basal ganglia. Patients with secondary intracerebral haemorhage, such as those using anticoagulants; those in whom subarachnoid haemorrage was suspected to be the primary underlyng cause, and those with lobar haematoma involving the cortex most likely to be associated with amyloid angiopathy or vascular malformation, were excluded.

Lacunar stroke was defined (1) as an acute stroke syndrome with a CT lesion compatible with occlusion of a single perforating artery, i.e., a small, subcortical, sharply marginated bypodense lesion with a diameter smaller than $20 \mathrm{~mm}$ (small deep infarct), or (2) as a specific lacunar syndrome (i.e., unilateral motor and/or sensory symptoms and signs that completely involve at least 2 of 3 body parts (face, arm, and leg) without disturbance of consciousness or language, visual field defect, or other signs of cortical dysfunction) when the CI scan showed no specific lesion.

Territorial stroke was defined (1) as an acute stroke syndrome with CT findings compatible with infarction involving the cortex, or (2) when no specific lesion was visible on $\mathrm{CT}^{2}$, as a clinically identified cortical syndrome consisting of unilateral motor and/or sensory symptoms and signs in combination with signs of cortical dysfunction with or without visual field defect, or as isolated monoparesis [16], or as isolated cortical dysfunction (usually dysphasia). Patients with a large subcortical infarct were included in the teritorial stroke group because of similar pathogenesis $[18,21]$.

\section{Patient population}

Eighty-three patients with a PICH were registered. PICH was confirmed by CT in 82 patients, and by autopsy in 1. Furthermore, we registered 247 lacunar and 457 territorial stroke patients, of whom 241 and 430 , respectively, had CT and entered the study.

\section{Statistical analysis}

Biwariate statistical analysis with crude odds ratios (c) OR) with $95 \%$ confidence intervals (CI) and subseqnent multivariate logistic regression analysis with adjusted odds ratios ((a)OR) with $95 \%$ CI determined the association of vascular risk factors with stroke subtype as dependent variable. The patients were categorized into 3 age groups: 65 years or younger, between 66 and 75 years, and older than 75 years.

\section{Results}

Table 2 shows the baseline characteristics of the three stroke groups. Median age was 69 (range: 42-89) years in PICH-patients, 68 (range: 26-93) years in lacunar stroke patients, and 73 (range: 24-96) years in territorial stroke patients. Patients with territorial stroke 
were significantly older than the other stroke patients ( $\chi^{2}$-test: vs. Iacunar stroke $p=0.0001$; vs. PICH $p=0.02$ ).

Table 2.1: Baseline characteristics of patients with primary intracerebral haemorrhage lacunar stroke, and territorial stroke.

\begin{tabular}{|c|c|c|c|c|}
\hline \multirow{2}{*}{\multicolumn{2}{|c|}{ Baseline characteristics }} & $\mathrm{PICH}$ & Lacunar stroke & Territorial stroke \\
\hline & & $N=83$ & $N=241$ & $N=430$ \\
\hline \multicolumn{2}{|l|}{ Male gender } & $44(53)$ & $131(54)$ & $220(51)$ \\
\hline \multirow[t]{3}{*}{ Age (years) } & $\leq 65$ & $34(41)$ & $89(37)$ & $110(26)$ \\
\hline & $66-75$ & $21(25)$ & $91(38)$ & $144(33)$ \\
\hline & $>75$ & $28(34)$ & $61(25)$ & $176(41)$ \\
\hline \multicolumn{2}{|c|}{ Hypertension } & $36(43)$ & $110(46)$ & $184(43)$ \\
\hline \multicolumn{2}{|c|}{ Diabetes mellitus } & $6(7)$ & $47(20)$ & $72(17)$ \\
\hline \multicolumn{2}{|c|}{ Ischaemic heart disease } & $2(2)$ & $46(19)$ & $122(28)$ \\
\hline \multicolumn{2}{|c|}{ Cardiac source of embolism } & $8(10)$ & $32(13)$ & $156(36)$ \\
\hline
\end{tabular}

Table 2.2 and Figure 2.1 show the crude and adjusted odds ratios with $95 \%$ confidence intervals of clinical variables comparing patients with PICH with those with lacunar or territorial stroke. Ischaemic heart disease was less strongly associated with PICH than with ischaemic stroke of either type (PICH vs. lacunar stroke: (a) OR 0.1, 95\% CI $0.03-$ 0.5 ; PICH vs. territorial stroke: (a) OR 0.1, 95\% CI 0.02-0.3). The probability of having diabetes mellitus was significantly smaller in patients with PICH than with both types of ischaemic stroke (PICH vs. lacunar stroke: (a)OR 0.3, 95\% CI 0.1-0.9; PICH vs. territorial stroke: (a) OR 0.4, 95\% CJ 0.2-1.0). A cardiac source of embolism was equally present in patients with PICH and with lacunar stroke, but significantly less frequent when PICH patients were compared with territorial stroke patients (a) OR $0.2,95 \%$ CI $0.1-0.4)$. Increasing age did not emerge as an independent variable associated with a specific stroke subtype. This was also the case with hypertension, the most frequent vascular risk factor in all three subgroups.

\section{Discussion}

Our study is not population-based, and may therefore suffer bias. Patients with deeply located brain haemorrhage may be the least liable to admission bias, whereas especially patients with a lacurar stroke may have been under-represented in our study because of lesser deficit in such patients. However, the Mastricht University Hospital, also serving as primary care facility, is the only hospital in our referral area. Furthermore, ambulant 
Table 2.2: Crude and adjusted odds ratios with $95 \%$ confidence intervals of climical variables comparing patients with primary intracerebral haemorrhage with those with lacunar or territorial stroke.

\begin{tabular}{|c|c|c|c|c|c|c|c|c|}
\hline \multirow[t]{2}{*}{ Vascular risk factors } & \multicolumn{4}{|c|}{ PICH ws. Lacunar stroke } & \multicolumn{4}{|c|}{ PICH vs. Territorial stroke } \\
\hline & (c)OR & $95 \% \mathrm{Cl}$ & (a)OR & $95 \% \mathrm{Cl}$ & (c)OR & $95 \% \mathrm{Cl}$ & (a)OR: & $95 \% \mathrm{Cl}$ \\
\hline $66-75$ vs. $\leq 65$ & 0.6 & $0.3-1.1$ & 0.6 & $0.3-1.2$ & 0.5 & $0.3-0.9$ & 0.6 & $0.3-1.2$ \\
\hline$>75$ vs. $\leq 65$ & 1.2 & $0.7-2.2$ & 1.3 & $0.7-2.4$ & 0.5 & $0.3-0.9$ & 0.8 & $0.4-1.5$ \\
\hline Male gender & $\mathbb{1} .0$ & $0.2-$ & 0.9 & & 1.1 & $0.5-2.3$ & 0.8 & $0.5-1.4$ \\
\hline Hypertension & 0.9 & $0.4-2.1$ & 0.9 & $0.5-1$ & 1.1 & $0.5-2.5$ & 1.1 & $0.7-1.8$ \\
\hline Diabetes mellitus & 0.3 & $0.1-0.8$ & 0.3 & $0.1-0.9$ & 0.4 & $0.2-1.0$ & 0.4 & $0.2-1.0$ \\
\hline Ischaemic heart disease & 0.1 & $0.03-0.4$ & 0.1 & $0.03-0.5$ & 0.1 & $0.02-0.2$ & 0.1 & $0.02-0.3$ \\
\hline Cardiac source of embolism & 0.7 & $0.2-2.0$ & 1.0 & $0.4-2.6$ & 0.2 & $0.1-0.4$ & 0.2 & $0.1-0.4$ \\
\hline
\end{tabular}

$\mathrm{P} \mid \mathrm{CH}=$ Primary intracerebral haemorthage. $\mathrm{Cl}=$ Confidence interval.

(c) $D R=$ Crude odds ratio. (a) $O R=$ Adjusted odds ratio.

patients visiting the out-patient clinic were also included, whereas the relative frequency of different infarct subgroups and the distribution of vascular risk factors among these subgroups were similar when compared with a population-based series [114]. Therefore, any referral bias in our study is likely to be small.

Because post-stroke-detected hypertension was inclucled as vascular risk factor, higher initial case fatality in PICH might have biased towards a lower detection of this feature in this subgroup compared with infarct cases. However, the lower proportion of hypertensive PICH patients who died within the first week compared with those surviving, respectively $11 / 31$ versus $25 / 52$ (OR $0.59,95 \%$ CI $0.19-1.87$ ), and the fact that in less than $4 \%$ of infarct patients hypertension was detected after stroke does not argue in favour of such bias.

Earlier we found no diference in the frequency of hypertension between lacunar, and territorial stroke patients without a potential cardio-embolic stroke source [17, 114]. Now we found a similar frequency in patients with a deeply located PICH. Hypertension may be an equally important, risk factor in lacumar stroke as in PICH. From pathological, clinical, and epidemiological studies hypertension emerged as the most strongly PICH-related risk factor $[33,53,146]$. In the Hisayama epidemiological study hypertension appeared to be the only risk factor associated with PICH in a multiple regression analysis [173]. Mohr et al. [134] found hypertension, defined as a blood pressure $\geq 160 / 100 \mathrm{mmHg}$, equally often in PICH as in lacunar stroke, but less frequently in patients with "large artery thrombosis". The higher diastolic blood pressure cut-off point in that study may explain the difference with our findings. The similar frequency of hypertension in PICH and lacumar stroke patients suggests that the underlying small-vessel disease may also be similar. However, we 

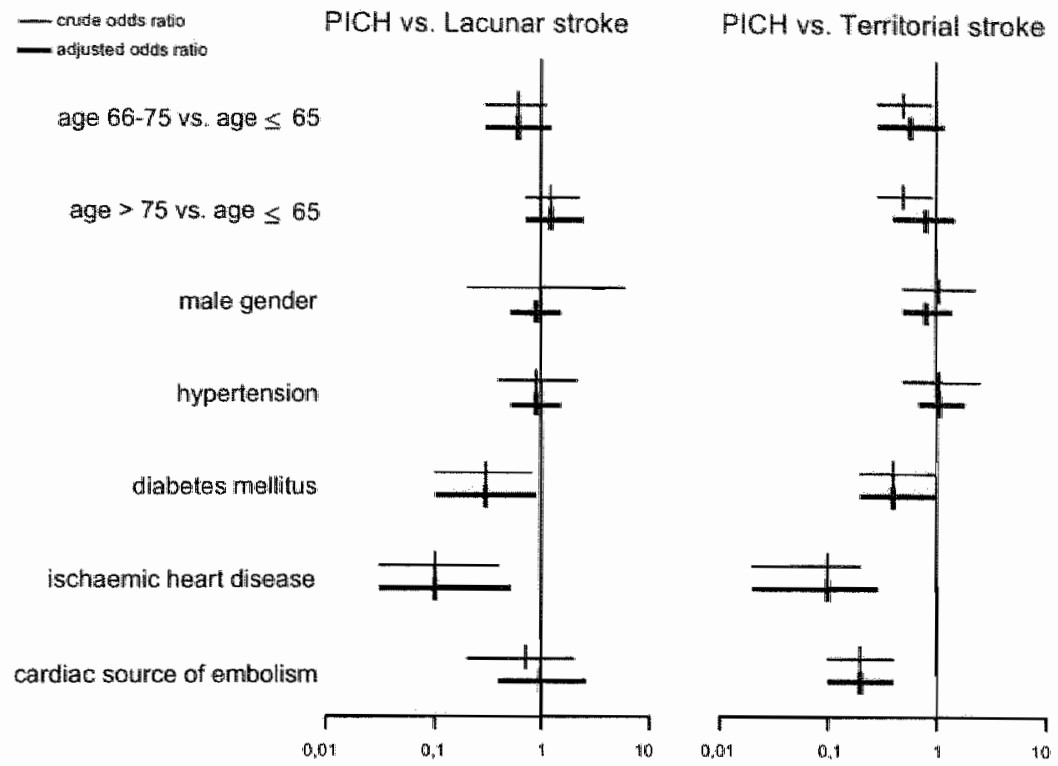

Figure 2.1: Crude and adjusted odds ratios with $95 \%$ confidence intervals of clinical variables comparing patients with primary intracerebral haemorhage (PICH) with those with lacunar or territorial stroke.

cannot rule out the possibility that PICH is related to higher blood pressure levels, hypertension of longer duration, or both. More severe hypertension may lead to arteriolosclerosis rather than atheromatosis of the small vessels $[20]$.

It is unclear why a substantial number of PICH as well as lacunar stroke patients are not hypertensive $[11,17,33,35,114,134]$. Diabetes may be involved in the development ol the small-vessel disease that leads to PICH. However, we found diabetes significantly less frequent in PICH than in the lacunar and territorial stroke pationts. Gross et al. [74] also found only 1 diabetic patient among 21 with PICH, whereas several stroke registries found diabetes mellitus also less prevalent in PICH than in brain infarction [14, 62, 134, 164]. Therefore, our clata and those of others do not suggest that diabetes mellitus is an essential factor in the small-vessel vasculopathy underlying PICH. The similar frequency of diallotes in lacunar and territorial stroke may reflect similar type of vasculopathy, which is most likely atheromatosis $[17,1.14]$. Similar reasoning may apply to a history of ischamic heart disease.

Comparison of risk factor profiles in our study lends support to the assumption that, although both PICH and symptomatic lacunar infarcts result from a cerebral small-vessel vasculopathy, the nature of this vasculopathy may differ between these stroke subtypes. In 
PICH arteriolosclerosis is the most prevalent vasculopathy $[53,60]$. However, pathological evidence, although scarce, points at atheromatosis as the cause of symptomatic small deep infarcts, whereas multiple, mostly silent small deep infarcts are caused by arteriolosclerosis $[34,58]$.

Of course one should realize that these inferences from our indirect clinical approach may not necessarily be true, and that definite confirmation awaits neuropathological data. It would be interesting to see how often stroke recurrences after lacunar stroke are PICH. If the number is low, this would support the notion of different types of underlying smallvessel pathology. Recurrent stroke following lacunar stroke is mostly ischaemic [19, 84], and in a minority haemorrhagic. However, intracerebral haemorrhage was found to be more frequent following lacunar stroke, than following territorial stroke [22].

Measuring the mere presence or absence of hypertension may be insufficient to detect all different stroke-related phenomena caused by hypertension. Duration and severity of hypertension, blood pressure variations, effects of treatment, concomitant hypertensive end-organ clamage, etc. may be relevant in this respect. Prospective studies in hypertensive patients could provide more insight into the question whether different types of hypertension eventually result in different stroke subtypes related to different types of cerebral small-vessel disease. 
3

Significant progression of white matter lesions and small deep (lacunar) infarcts in stroke patients

Adapted from:

Van Zagten M, Boiten J, Kessels F, Lodder J. Significant progression of white matter lesions and small deep (lacunar) infarcts in patients with stroke. Arch Neurol 1996;53:650-655. 


\section{Abstract}

Objectives: To investigate whether the extent of white matter lesions (WMLs) and the number of small deep and territorial infarcts progress over time in stroke patients and to test the hypothesis that WMLs are associated with small deep infarcts.

Design: Computed tomographic (CT) follow-up study in a cohort of 107 ischaemic stroke patients (median follow-up 3.0 years).

Setting: Primary and referral care centre.

Patients: Sixty-three of 144 registered patients with a first-ever symptomatic lacunar stroke and 44 of 155 with a terrtoriall stroke entered this study. Forty-seven (33\%) of the non-participating patients with a lacunar stroke and $54(35 \%)$ of those with a territorial stroke died, and $34(24 \%)$ and $57(37 \%)$, respectively, refused CT follow-up.

Main outcome measures: The extent of the WMLs and the number of small deep and territorial infarcts on Cr. scans at study entry and at follow-np.

Results: Progression of WMLs occurred in 26 patients $(26 \%)$, and multivariate regression analysis showed that it was associated with symptomatic lacunar stroke at study entry, silent small deep infarcts at study entry, old age and longer follow-up. We found progression of small deep infarcts in 41 patients $(38 \%)$. The progression was associated with symptomatic lacunar stroke at study entry and longer follow-up. Progression of both WMLs and small deep infarcts, which occurred in 16 patients (16\%), was related to symptomatic lacumar stroke at study entry, silent small deep infarcts at study entry and longer follow-up. The number of territorial infarcts increased in 14 patients (13\%). The increase was associated with symptomatic territorial stroke at study entry and a history of ischaemic heart disease.

Conclusions: The marked progression of WMLs and small deep infarcts that occurred mainly in lacunar stroke patients suggests that both WMLs and small deep (lacumar) infarcts are caused by a similar vasculopathy that affects small vessels, which is progressive despite standard stroke treatment. 


\section{Introduction}

Since the imtroduction of computed tomography (CT), per: (WMLs), often called leukoaraiosis [78] have attracted muc found in patients with dementia, both in those with vasc Alzheimer disease, but also in normal subjects and in pati factors $[4,15,26,30,31,36,50,63,66,87,90,100,154,16$ WMLs are associated with small deep (lacunar) infarcts, es and with deep intracerebral haemorrhage $[15,20,32,87]$, and small deep infarcts are caused by a similar vasculopat

Whether the extent of WMLs and the number of $\mathrm{sm}$ progress over time is unknown, because brain imaging fol' performed. We report the results of a prospective CT foll first-ever brain infarct. The aim of this study was to ans WMLs and the number of small deep and territorial infa there an association between either of these infarct subtyl progress more markedly in lacunar rather than in territo vascular risk factors predict progression of WMLs?

\section{Patients and methods}

Patients were registered at the University Hospital of Ma: June 1992 in a prospective registry of all patients, admit clinic, with a first-ever supratentorial brain infarct with 24 hours. Routine investigations included standard blood $X-r a y, C T$ scan of the brain, and noninvalive carotid stud ECG monitoring, and cerebral angiography were done in $s$

\section{Definitions}

The following wascular risk factors were recorded: age, gend tension, or at least 2 separate blood pressure recordings of fore or at least 1 week after stroke), diabetes mellitus (kno serumgl ucose higher than $7 \mathrm{mmol} / \mathrm{l}$, or a postprandial serum: both on at least 2 separate occasions), hypercholesterolemiz or serumcholesterol higher than $6.4 \mathrm{mmol} / \mathrm{l}$, history of isc dial infarction, angina pectoris), history of chronic obstructi smoking, cardiac source of embolism (atrial fibrillation, $m$ or mitral valwe, recent myocardial infarction (within 6 week tis, cardiomyopathy, left ventricular aneurysm, intraventric 
(more than 50\%) carotid stenosis ipsilateral to the symptomatic stroke.

Lacunar stroke was defined (1) as an acute stroke syndrome with a CT lesion compatible with occlusion of a single perforating artery, i.e., a small, subcortical, sharply marginated hypodense lesion with a diameter smaller than $20 \mathrm{~mm}$ (small deep infarct), or (2) as a specific lacunar syndrome (i.e., unilateral motor and/or sensory symptoms and signs that completely inwolve at least 2 of 3 body parts (face, arm, and leg) without disturbance of consciousness or language, visual field defect, or other signs of cortical dysfunction) when the CT scan showed no specific lesion.

Territorial stroke was defined (1) as an acute stroke syndrome with CT findings compatible with infarction involving the cortex, or (2) when no specific lesion was visible on CT, as a clinically identified cortical syndrome consisting of unilateral motor and/or sensory symptoms and signs in combination with signs of cortical dysfunction with or without visual field defect, or as incomplete involvement of 2 body parts, or as isolated monoparesis [16], or as isolated cortical dysfunction (usually dysphasia). Patients with a large subcortical infarct were included in the territorial stroke group because of similar pathogenesis $[18,21]$. In the study, we included patients with lacumar stroke, presumably due to small-vessel occlusion, and patients with territorial stroke, presumably due to large-vessel atherosclerosis. Patients with a cardiac source of embolism or a specific stroke cause such as vasculitis or arterial dissection were not included.

Silent brain infarct was defined as a low-density area on CT compatible with infarction but without a history of stroke, as taken from the patient's history, from family, or any other accessible information. Also, the stroke symptoms at study entry had to be anatomically incompatible with this infarct. Old infarcts can usually be distinguished from new ones because they are more hypodense, and there may be signs of surrounding tissue loss, like retraction of brain structures towards the infarct. Silent infarcts were also categorized as small deep or territorial.

Progression of small deep or territorial infarcts was defined as new symptomatic or silent infarcts visible on the CT at follow-up, which were not visible on the CT at study entry.

White matfer lesions were defined as focal or diffuse hypodensities in the periventricular or deep white matter, not involving the cortex, and with ill-defined margins to distinguish them from infarction [168]. The presence of WMLs around frontal or occipital horns or in the centrum semiovale was noted separately. No effort was made to quantify the degree of white matter density in these different sites, as this might depend on the tuning of the CT scan. Patients were said to have WML progression when the CT at study entry showed no WMLs, whereas the CT at follow-up did show WMLs, or when patients who had WMLs at study entry had new WMLs in other areas on the CT at follow-up. 


\section{Patient population}

Sixty-three of 144 consecutively registered patients with a symptomatic lacunar and 44 of 155 with a symptomatic territorial stroke entered this follow-up study. Of the remaining patients, $47(33 \%)$ with a lacunar stroke and $54(35 \%)$ with a territorial stroke had died, and $34(24 \%)$ and $57(37 \%)$, respectively, refused follow-up CT, mainly because they were unable to visit the out-patient clinic owing to severe disablement. Table 3.1 shows baseline characteristics of those registered patients who did not enter this follow-tip study and were still alive at time of follow-up. The patients who did not participate were older and had a higher Rankin (handicap) score than patients participating in the follow-up study. The median follow-up for all study patients was 3.0 (range: $1.2-4.7$ ) years: 2.8 (range: 1.2 4.3) years for those with a lacunar stroke and 3.2 (range: 1.7-4.7) years for those with a territorial stroke. All patients underwent CT at study entry and at follow-up. The median time between CT at study entry and at follow-up was 2.9 (range: $1.1-4.7$ ) years: 2.8 (range: 1.2-4.3) years for patients with a lacunar stroke and 2.9 (range: 1.1-4.7) years for patients with a territorial stroke. The CT scans obtained at study entry and at followup were mixed together and then reviewed for the presence and extensiveness of WMLS and for the number of small deep and territorial infarcts by 2 neurologists who were blind to the patients' identity and the timing of the CT. Only those WMLs and infarcts on which both investigators agreed were registered. A third investigator analyzed whether the extensiveness of WMLs and/or the number of infarcts had changed during follow-up.

Table 3.1: Baseline characteristics of lacunar and territorial stroke patients, not entering this follow-up study and alive at time of follow-up.

\begin{tabular}{|c|c|c|c|}
\hline \multicolumn{2}{|c|}{ Baseline characteristics } & $\begin{array}{l}\text { Lacunar stroke } \\
\qquad N=34\end{array}$ & $\begin{array}{l}\text { Territorial stroke } \\
\qquad N=57\end{array}$ \\
\hline \multicolumn{2}{|l|}{ Male gender } & $13(38)$ & $34(60)$ \\
\hline \multirow{3}{*}{ Age (years) } & $\leq 60$ & $4(12)$ & $18(32)$ \\
\hline & $61-67$ & $7(21)$ & $7(12)$ \\
\hline & $>67$ & $23(68)$ & $32(56)$ \\
\hline \multicolumn{2}{|c|}{ Hypertension } & $17(50)$ & $27(47)$ \\
\hline \multicolumn{2}{|c|}{ Diabetes mellitus } & $5(15)$ & $7(12)$ \\
\hline \multicolumn{2}{|c|}{ Hypercholesterolemia } & $3(9)$ & $16(28)$ \\
\hline \multicolumn{2}{|c|}{ Ischaemic heart disease } & $5(15)$ & $16(28)$ \\
\hline \multicolumn{2}{|c|}{ COPD } & $3(9)$ & $3(5)$ \\
\hline \multicolumn{2}{|c|}{ Smoking } & $8(24)$ & $28(49)$ \\
\hline \multicolumn{2}{|c|}{ Carotid stenosis } & $2(6)$ & $13(23)$ \\
\hline \multicolumn{2}{|c|}{ Rankin 3 months $=4$ or 5} & $4(12)$ & $12(21)$ \\
\hline
\end{tabular}

$\mathrm{COPD}=$ Chronic obstructive pulmonary disease.

Percentages between parentheses. 


\section{Statistical analysis}

We related changes in $\mathrm{C}$ parameters to clinical variables by means of bivariate statistical analysis with crude odds ratios (c)OR) with $95 \%$ confidence intervals (C). Multivariate logistic regression analysis with adjusted odds ratios ((a)OR) determined the association of the clinical variables with 4 dependent variables: (1) progression of WMLs, (2) increased number of small deep infarcts, (3) progression of territorial infarcts, and (4) progression of both WMLs and small deep infarcts. Besides the vascular risk factors, the following clinical variables were included in various regression models: stroke subtype, presence of WMLs, silent small deep or territorial infarcts at study entry, Rankin (handicap) score at 3 months after stroke and at follow-up, and duration of follow-up. The Rankin scores were divided into 2 groups: functionally independent (Rankin $\leq 3$ ) or dependent (Rankin $=4$ or 5). Patients were categorized into 3 age groups: 60 years or younger, 61 to 67 years, and older than 67 years. The duration of follow-up was divided into 4 categories: less than 900 days, 900 to 1200 days, 1200 to 1400 days, and 1400 days or more. For all dependent variables, the 2 "higher-age" categories and the 3 "longer-duration of follow-up" categories were compared with the youngest age and shortest follow-up categories, respectively.

\section{Results}

Table 3.2 shows the baseline characteristics of the lacunar and territorial stroke patients, who participated in this study. The median age was 58 (range: 30-85) years: 58 (range: 30-85) years in lacunar and 60 (range: 37-82) years in territorial stroke patients. The number of patients in the different age groups did not differ significantly between the 2 patient groups. There was an unbalanced distribution of follow-up duration in the lacumar and territorial stroke patients in the 900- to 1200 -day category $\left(21 \%\right.$ vs. $36 \%, \chi^{2}$-test: $p=0.02$ ), and 1200 - to 1400 -day category ( $33 \%$ vs. $14 \%, \chi^{2}$-test: $p=0.07$ ).

Table 3.3 and Frgure 3.1 show the results of the bivariate and multivariate logistic regression analysis of the most relevant model of clinical variables, expressed as (c)OR and (a)OR, respectively, in the 4 patient groups, i.e., those with progression of WMLs, those with progression of small deep infarcts, those with progression of both WMLs and small deep infarcts, and those with progression of territorial infarcts.

\section{Progression of WMLs}

At study entry, WMLs were equally frequent in lacunar $(16 \%)$, and in territorial stroke patients (14\%) (Table 3.2). Three lacunar and three territorial stroke patients who alrearly had maximal extensiveness of WMLs at study entry were excluded from the analysis, because they did not show funther WML progression. The WMLs progressed in 26 patients (26\%): 22 with a lacunar and 4 with a territorial stroke. This means that WML progression was significantly associated with lacunar stroke ((a)OR 5.0,95\% CI 1.2-20.3). In 1 
Table 3.2: Baseline characteristics of patients with a lacunar or teritorial stroke participating in the follow-up study.

\begin{tabular}{|c|c|c|c|c|}
\hline \multicolumn{2}{|c|}{ Baseline characteristics } & $\begin{array}{l}\text { Lacunar stroke } \\
N=63(59)\end{array}$ & $\begin{array}{l}\text { Territorial stroke } \\
N=44(41)\end{array}$ & $\begin{array}{c}\text { Total } \\
N=107\end{array}$ \\
\hline \multicolumn{2}{|l|}{ Malle gender } & $43(68)$ & $27(61)$ & $70(65)$ \\
\hline \multirow[t]{3}{*}{ Age (years) } & $\leq 60$ & $21(33)$ & $20(45)$ & $41(38)$ \\
\hline & $61-67$ & $22(35)$ & $10(23)$ & $32(30)$ \\
\hline & $>67$ & $20(32)$ & $14(32)$ & $34(32)$ \\
\hline \multicolumn{2}{|l|}{ Hypertension } & $28(44)$ & $16(36)$ & $44(41)$ \\
\hline \multicolumn{2}{|c|}{ Diabetes mellitus } & $12(19)$ & $7(16)$ & $19(18)$ \\
\hline \multicolumn{2}{|c|}{ Hypercholesterolemia } & $32(51)$ & $18(41)$ & $50(47)$ \\
\hline \multicolumn{2}{|c|}{ Ischaemic heart disease } & $8(13)$ & $13(30)$ & $21(20)$ \\
\hline \multicolumn{2}{|c|}{ COPD } & $5(8)$ & $3(7)$ & $8(7)$ \\
\hline \multicolumn{2}{|l|}{ Smoking } & $20(32)$ & $17(39)$ & $37(35)$ \\
\hline \multicolumn{2}{|c|}{ Carotid stenosis } & $3(5)$ & $14(32)$ & $17(16)$ \\
\hline \multicolumn{2}{|c|}{ WMLs at study entry } & $10(16)$ & $6(14)$ & $16(15)$ \\
\hline \multicolumn{2}{|c|}{ Silent SDIs at study entry } & $10(16)$ & $7(16)$ & $17(16)$ \\
\hline \multicolumn{2}{|c|}{ Sillent Tls at study entry } & $1(2)$ & 0 & $1(1)$ \\
\hline \multicolumn{2}{|c|}{ Rankin at 3 months $=4$ or 5} & $2(3)$ & $4(9)$ & $6(6)$ \\
\hline \multicolumn{2}{|c|}{ Rankin at follow-up $=4$ or 5} & $1(2)$ & $5(11)$ & $6(6)$ \\
\hline \multirow[t]{4}{*}{ Follow-up (days) } & $<900$ & $14(22)$ & $11(25)$ & $25(23)$ \\
\hline & $900-1200$ & $13(21)$ & $16(36)$ & $29(27)$ \\
\hline & $1200-1400$ & 21 (33) & $6(14)$ & $27(25)$ \\
\hline & $\geq 1400$ & $15(24)$ & $11(25)$ & $26(24)$ \\
\hline
\end{tabular}

COPD $=$ Chronic obstructive pulmonary disease. WMLs $=$ White matter lesions. SDIs $=$ Small deep infarcts. Tls $=$ Territorial infarcts.

Percentages between parentheses.

lacumar and 1 territorial stroke patient, CT scans at study entry showed WMLs around the frontal and occipital horns, respectively, whereas follow-up CT scans were without WMLs. In 1 territorial stroke patient the CT scan at study entry showed WMLs in all regions, whereas the follow-up CT scan showed WMLs only around frontal horns and in the centrum semiovale. Besides the association with lacunar stroke, progression of WMLs was also significantly associated with silent small deep infarcts on CT at study entry ((a)OR 6.0, $95 \%$ CI 1.0-34.6), old age (age > 67 vs. age $\leq 60:$ (a)OR 5.5, 95\% CI 1.3 23.1), and longer follow-up (follow up $>1400$ vs. < 900 days: (a) OR 12.7, 95\% CI 1.8-89.0). When diabetes mellitus was added to the multivariate regression model, it was associated with less progression of WMLS ( a ) OR $0.03,95 \%$ CI $0.0-0.4)$. 


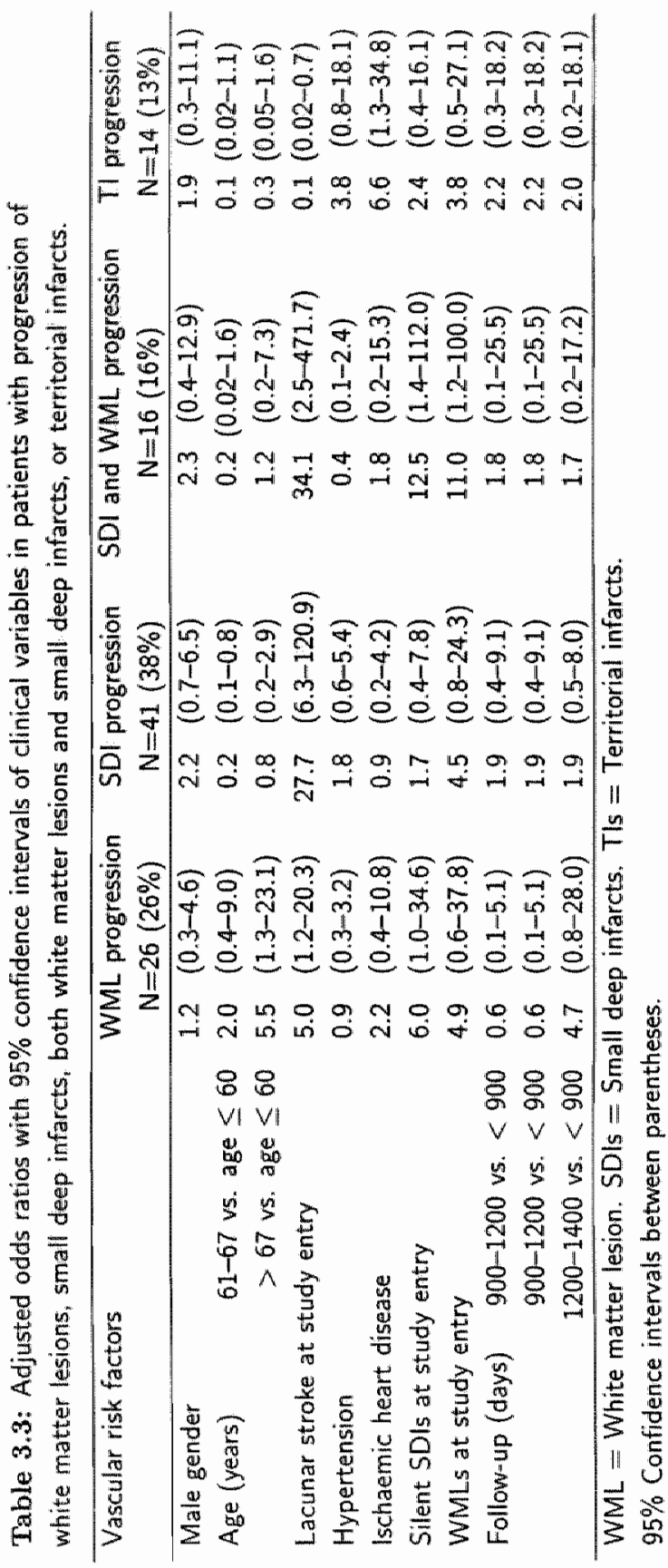




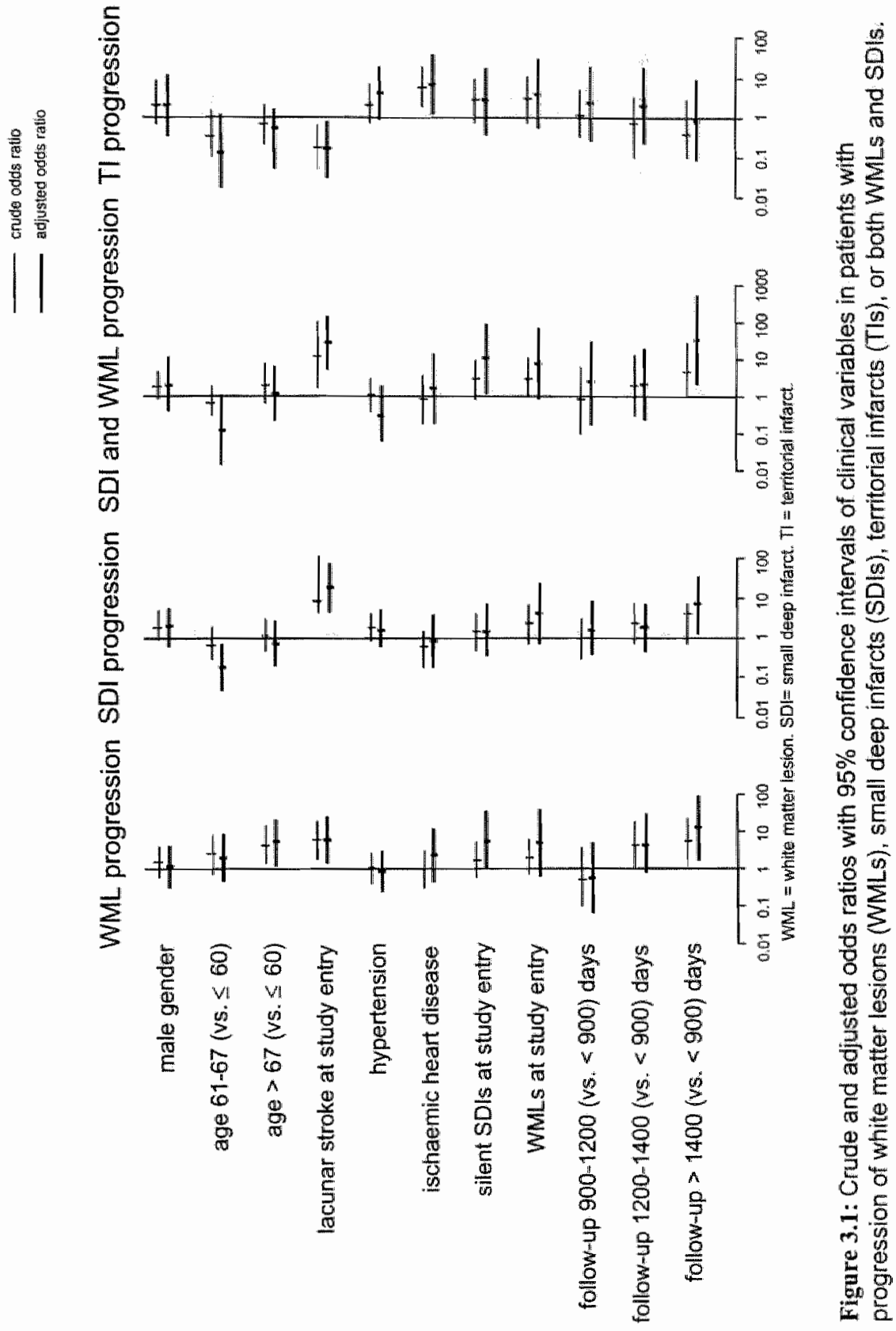




\section{Progression of small deep infarcts}

We found progression of small deep infarets in 41 patients (38\%), 37 lacunar and 4 territorial stroke patients, which demonstrates a silgnificant association of progression of small deep infarcts with symptomatic lacunar stroke at study entry ((a)OR $27.7,95 \%$ CI 6.3-120.9). In 5 lacunar and 2 territorial stroke patients recurrent infarcts were symptomatic. Progression of small deep infarcts was independently associated with longer follow-up (follow-up $>1400$ vs. < 900 days: (a)OR 7.7, 95\% CI 1.4-41.3), and, inversely, with age between 61 and 67 years (compared with patients younger than 61: (a)OR 0.2, 95\% CI 0.1-0.8). Progression of small deep infarcts was significantly associated with WML progression ((c)OR 3.6, 95\% CI 1.4-9.2), but not independently ((a)OR 1.4,95\% CI 0.4-5.4). After stepwise stripping of the multivariate regression analysis model, it appeared that the type of stroke at study entry was responsible for this considerabje difference in OR.

\section{Progression of both WMLs and small deep infarcts}

Six patients who had maximal extension of WMLs on CT at study entry were excluded from the analysis. Progression of both WMLs and small deep infarcts occurred in 16 patients $(16 \%), 15$ lacunar and 1 territorial stroke patient, demonstrating a significant association of progression of both WMLs and small deep infarcts with symptomatic lacunar stroke at study entry ((a)OR 34.1, 95\% CI 2.5-471.7). In contrast, only 3 patients had progression of both WMLs and territorial infarcts. Progression of both WMLs and small deep infarcts was also significantly associated with silent small deep infarcts at study entry ((a)OR 12.5, 95\% CI 1.4-112.0), and with longer follow-up (follow-up > 1400 vs. < 900 days: (a)OR 29.7, $95 \%$ CI 1.8-501.0).

\section{Progression of territorial infarcts}

The number of territorial infarcts increased in 14 patients (13\%), of whom 3 had a lacunar and 11 a territorial stroke. The recurrent infarct was symptomatic in only 1 (territorial stroke) patient. The progression of territorial infarcts was significantly associated with symptomatic territorial stroke at study entry (lacunar ws. territorial stroke: (a)OR 0.1, $95 \% \mathrm{CI} 0.02-0.7)$ and with a history of ischaemic heart disease ((a)OR $6.6,95 \% \mathrm{CI} 1.3-$ $34.8)$.

Remarkably, the progression of small deep infarcts in lacunar stroke patients occurred significantly more than progression of territorial infarcts in territorial stroke patients ( (c)OR. $4.3,95 \%$ CI $1.8-10.0)$.

\section{Rankin (handicap) score}

The degree of handicap as measured by the Rankin score at 3 months after initial stroke and at follow-up was not associated with progression of WMLs, small cleep or territorial infarcts, or with both WMLs and small deep infarcts. The handicap increased in 36 patients (34\%) 
(26 with a lacunar and 10 with a territorial stroke); it decreased in 26 patients (24\%) (10 with a lacunar and 16 with a territorial stroke); and it remained unehanged in 45 patients (42\%) (27 with a lacunar and 18 with a territorial stroke).

\section{Discussion}

After a median follow-up of 3.0 years, WMLs had progressed in $24 \%$ of the study patients with an ischaemic stroke. This progression was much more pronounced in lacunar than in territorial stroke patients. The progression of WMLs was significantly associated with symptomatic lacunar stroke and with silent small deep infarcts at study entry. These findings are in line with those of our earlier CT study, which showed WMLs to be signifficantly associated with the presence of silent small deep infarcts [20]. Also, we found marked progression of small deep infarcts in lacunar stroke patients.

Not all patients initially included in our stroke registry were available for follow-up CT, which may have created bias, but, if so, the bias was most likely toward underdetection of WMLs and recurrent infarcts: most patients not investigated had died or were severely disabled; therefore, the younger and relatively less disabled patients participated in the study. The progression of WMLs and infarcts might have been even worse if more severely affected patients had also been included.

In 3 patients, the initial CT scans showed more extensive WMLs than the follow-up CT scans. In search for an explanation of this apparently odd finding, we reviewed the 2 CT scans of each patient. In these 3 patients, the follow-up CT scans showed diminished black-and-white contrast compared with the initial CT scans, which may have led to an underestimation of the extensiveness of WMLs. Furthermore, 1 of the 3 patients had WMLs around the occipital horns on the initial CT scan. The follow-up CT scan in this patient showed a large infarct in the territory of the middle cerebral artery extending around the oceipital horn, which interfered with judgement of WMLs in this aren. There were no signs of ventricular enlargement or changes in ventricular size in follow-up CT scans compared with the initial CT scans in these 3 patients. Therefore, intraobserver variability, rather than real change, such as might occur in periventricular. WMLs related to (normal pressure) hydrocephalus $[51,56,106,132]$, may explain these discrepanciss.

Progression of small deep infarcts occurred significantly more often in lacunar stroke patients, and progression of territorial infarcts in territorial stroke patients. Those lind ings support the hypothesis of different underlying vasculopathies in small deep (lacunar) infarcts and in (non-cardio-embolic) territorial infarcts, i.e., small-vessel disease and largevessel disease, respectively $[11,19,97,114,131,142,178]$. The association of territorial infarct progression with ischaemic heart disease also supports the relationship of territorial infarcts with generalized large-vessel atherosclerosis. The unexpected inverse association of patient age between 61 and 67 years, compared with patient age 60 yoars or younger, 
with increase in the number of small deep infarcts is probably related to the relative small numbers of patients in the different age groups.

Most recurrent infarcts were silent. Two previous follow-up studies found similar results. In a 1-year magnetic resonance imaging follow-up study of 81 lacunar stroke patients, Samuelsson et al. [160] found 5 recurrent symptomatic strokes, 4 of which were small deep and 1 of which was territorial, and 9 new silent infarcts, 5 of which were territorial and 4 of which were small deep. In a CT follow-up study of 24 patients with vascular dementia (follow-up $42 \pm 27$ [mean $\pm S D$ ] months) and 24 with dementia of the Alzheimer type, Meyer et al. [130] found recurrent silent infarcts in 4 patients with vascular dementia, all of which were small deep.

Several vascular risk factors have been associated with WMLs. Among these factors are increasing age $[4,30,32,37,81,87,96,113,122,171,186,193]$, hypertension $[4$, $15,30,32,52,112,122,186]$, heart disease $[30,52,113,193]$, hypercholesterolemia [30], diabetes mellitus [193], and carotid stenosis [52]. We could only confirm the association of increasing age with WML progression. Unexpectedly, WML progression was related to the absence of diabetes mellitus. This finding may be the result of a selection bias, but diabetes mellitus was not significantly more frequent among patients who did not participate in this study. A more likely explanation may be a random variation due to the small number of patients involved, because there was only 1 patient with diabetes mellitus among those with WML progression. We did not find an association of WML progression with other vascular risk factors, such as hypertension. Some authors also found no relationship between hypertension and WMLs [96, 193]. Possibly, hypertension may not be identified as a cliscriminator among a population that already has a high frequency of hypertension. Moreover, Liao et al. [112] found that the level of blood pressure is related to WMLs. So, antihypertensive treatment in our study patients may have weakened the effect of hypertension as a risk factor.

Meyer et al. [130] demonstrated that cognitive decline correlated with recurrent silent infarcts and with changes in local cerebral biood flow of the frontal white matter, thalamus and internal capsule. Both WMLs and multiple, usually silent, small deep infarcts have been associated with mental impairment and dementia $[72,94,100,169,182]$, and with multiple neurological deficits, such as gait disorders, tendency to fall, pseudobulbar state, and incontinence $[6,94,169]$. In our study, progression of WMLs and increase in the numbers of small deep or territorial infarcts were not associated with increased handicap. However, as stated earlier, patient selection may have created bias, because patients not included were more severely disabled. Recently, we could not find an association between silent lesions in infarct patients and functional outcome at 1 year [23]. Obviousiy, there is no clear relationship between silent infarcts, WML progression, and functional outcome in brain infarct patients.

The marked progression of WMLs that occurred mainly in lacunar stroke patients sug- 
gests that both WMLs and small deep infarcts are due to small-vessel disease, as has been suggested by others $[15,32,87]$. The impressive increase over time of WMLs and of small deep infarcts in our patients suggestic that the underlying small-vessel disease is progressive. Autopsy studies in patients with WMLs on CT or magnetic resonance imaging scars showed diffuse demyelination of the white matter multiple small deep infarcts, cystic lacunae, dilated perivascular spaces, and arteriolosclerosis $[3,27,28,31,36,41,72,100,101$, $125,153,156]$. More rarely, amyloid angiopathy $[73,95]$ or noninflammatory collagenous thickening of venous walls resulting in severe periventricular venous stenosis [136] were found. Recently, arteriolosclerosis was suggested as the primary factor in the pathogenesis of these diffuse WMLs, whereas dilatation of perivascular spaces was considered as secondary event [187]. Fisher $[55,57]$ showed at antopsy that arteriolosclerosis is also related to multiple, usually silent small deep infarcts. So, these various autopsy studies showed (1) that both WMLs and multiple small deep infarcts result from a vascular disease and (2) that in most patients this vascular disease may be arteriolosclerosis. These observations are remarkable, because WMLs and small deep infarcts mainiy occur in different vascular territories: small deep infarcts in the territory of small deep penetrating arteries, and WMLs in the territory of the superficial perforating branches of large cerebral arteries. The vasculopathy that results in WMLs and small deep infarcts may therefore be pathologically bomogeneous but heterogeneous as to the affected cerebral vascular system. What causes deep perforating vessels to react with infarction and the superficial system with "incomplete infarction" and demyelination remains unclear, but factors such as local perfusion pressure and autoregulatory differences between the 2 systems may be involved.

Recently, Hachinski [76] pointed out that vascular dementia is currently the only preventable major cause of dementia. Prevention should be tried in patients in the "brain-atrisk" stage (e.g., patients with vascular risk factors), in patients in the predementia stage (e.g., stroke patients), and in patients who already have dementia. Our strolke patients were treated according to present standards, i.e., treatment of vascular risk factors (e.g., with antismoking advice, antihypertensives, antidiabetics, and diet) and treatment with aspirin or anticoagulants. It is both amazing and disappointing that. WMLs and small decp infarcts were rapidly progressive despite this standard stroke treatment. Fisher [55, 57] suggested that severe and long-standing hypertension might be a particular cause of arteriolosclenosis. The notion that arteriolosclerosis progresses despite standard stroke treatment, inclucling the lowering of elevated blood pressure levels, could mean that hypertensive patients should be treated more diligently or that wascular disease, once it has produced stroke, haw arlwanced too far to be influenced significantly by therapy, although therapy reduces the risk of symptomatic recurrent stroke. Another reason may be that other, as yet unknown (environmental or genetic), factors influence the pathogenesis of cerebral anteriolosclerosis. Fortunately, despite significant progression, the vasculopathy does not seem to significantly impair the degree of handicap. Whether it may affect the degree of cognitiwe impaimment 
remains to be determined. 
4

Strong association between white matter lesions and multiple small deep infarcts suggests similar type of underlying small-vessel disease 


\section{Abstract}

Objectives: (1) To investigate the incidence of white matter lesions (WMLs) in first-ever ischaemic stroke patients. (2) To study WMLs in relationship with vascular risk factors, symptomatic and silent infarcts, to test the hypothesis that WMLs are especially associated with multiple, usually silent small deep infarcts.

Design: Survey of prospectively registered patients with a first-ever supratentorial ischaemic stroke, of whom vascular risk factors were registered, and whose computed tomographic (CT) scans were reviewed for presence of WMLs and silent small deep or territorial infarcts.

Setting: Primary and referral care centre.

Patients: Of 999 consecutively registered patients, 39 patients were excluded: 37 because at CT scan of the brain had not been performed, 2 because the CT scan could not be retrieved. So, 960 patients entered this study: 332 patients with a lacunar stroke, 213 with a cardio-embolic territorial stroke, and 415 with a atherothrombotic territorial stroke.

Main outcome measure: WMLs on brain CT scan.

Results: $24 \%$ of all stroke patients had WMLs. WMLs were associated with higher age, lacunar stroke and silent small deep infarcts. Furthermore, WMLs were associated with silent territorial infarcts in the atherothrombotic stroke subgroup.

Conclusions: A considerable percentage of stroke patients have WMLs, which are associated with especially silent small deep infarcts and higher age. These findings support the lypothesis that WMLs and multiple, usually silent small deep infarcts have the same vascular cause, namely arteriolosclerosis. 


\section{Introduction}

Hachinski [78] was one of the first to draw attention to white matter lesions (WMLs), often called leukoaraiosis. Since then a vast amount of studies on WMLs have been published. WMLs have been studied in the general population $[30,52,49,113,193]$, in patients with bypertension [186], in stroke patients $[81,87,91,96,99]$, and in patients with dementia [12, $31,32,105,111,154,169]$. WMLs were found to be related to higher age $[4,30,32,37$, $81,87,96,122,171,193]$, and several vascular risk factors $[4,30,32,113,122,193]$.

Like small deep (lacunar) infarcts, WMLs are thought to be caused by small-vessel disease $[31,64,66,187]$. Associations of WMLs with small deep infarcts have been found in a stroke population [87], a neurogeriatric population [32], and in neurologically nondiseased elderly subjects [193]. Pathological [34,58] as well as clinical $[20,127]$ evidence points at two distinct small deep (lacunar) infarct entities: arteriolosclerosis as the cause of multiple, usually silent, small deep infarcts, whereas the somewhat larger, symptomatic ones are caused by microatheromatosis. Pathological studies showed that arteriolosclerosis is also the underlying vasculopathy in WMLs $[31,64,66,187]$. So, one could expect that WMLs occur more frequently in patients with multiple, usually silent small deep infarcts than in those with single larger symptomatic lacunar infarcts. Furthermore, the risk factor profile of WMLs could clarify the factors involved in the development of arteriolosclerosis. The aims of this study were (1) to investigate the incidence of WMLs in patients with a first ever ischaemic stroke, and (2) to study WMLs in relationship with vascular risk factors and with symptomatic as well as silent infarct subtypes, to test the hypothesis that WMLs are especially associated with multiple, usually silent small deep infarcts.

\section{Patients and methods}

Patients were registered at the University Hospital of Maastricht between July 1987 and January 1994 in a prospective registry of all patients, admitted or visiting the ont-patient clinic, with a first-ever supratentorial brain infarct with symptoms lasting longer than. 24 hours. Routine investigations included standard blood tests, electrocardiogram, chest: $\mathrm{X}$-ray, computed tomographic (CT) scan of the brain, and noninvasive carotid studies. Echocardiography, 24-hour ECG monitoring, and cerebral angiography were done in selected cases.

\section{Definitions}

The following possible wascular risk factors were reconded: age, gender, hypertension (known hypertension, or at least, 2 separate blood pressure recordings of higher than $160 / 90 \mathrm{mmHg}$ before or at least 1 week after stroke), diabetes mellitus (known dimbetes mellitus, or fasting serumglucose higher than $7 \mathrm{mmol} / 1$, or a postprandial serumglucose 
higher than $11 \mathrm{mmol} / 1$, both on at least 2 separate occasions), haematocrit at stroke onset, history of ischamic heart disease (myocardial infarction, angina pectoris), history of chronic obstructwe pulmonary disease (COPD), cardiac source of embolism (atrial fibrillation, mitral stenosis, prosthetic abrtic or mitral valve, recent myocardial infarction (with in 6 weeks preceding stroke), endocarditis, cardiomyopathy, left ventricular aneurysm, intraventricular thrombus), use of diuretics prior to stroke, and significant (more than $50 \%$ ) carotid stenosis ipsillateral to the symptomatic stroke.

Lacunar stroke was defined (1) as an acute stroke syndrome with aT lesion compatible with occlusion of a single perforating artery, i.e., a small, subcortical, sharply marginated hypodlense lesion with a diameter smaller than $20 \mathrm{~mm}$ (small deep infarct), or (2) as a specific lacunar syndrome (i.e., unilateral motor and/or sensory symptoms and signs that completely involve at least 2 of 3 body parts (face, arm, leg) without disturbance of consciousness or language, visual field defect or other signs of cortical dysfunction) when the CT scan showed no specific lesion.

Territorial stroke was defined (1) as an acute stroke syndrome with CT findings compatible with infarction involving the cortex, or (2) when no specific lesion was visible on CT, as a clinically identified cortical syndrome consisting of unilateral motor and/or sensory symptoms and signs in combination with signs of cortical dysfunction with or without visual field defect, or as incomplete involvement of 2 body parts, or as isolated monoparesis [16], or as isolated cortical dysfunction (usually dysphasia). Patients with a large subcortical infarct were included in the territorial stroke group because of similar pathogenesis $[18,21]$. By presumed stroke cause, 3 territorial stroke subtypes were discerned: cardio-embolic, atherothrombotic, and territorial stroke with undetermined cause. Cardio-embolic territorial stroke was defined as a territorial stroke in the presence of a cardiac source of embolism. Atherothrombotic stroke was defined as a territorial stroke in the presence of a significant carotid stenosis. If neither a cardiac source of embolism nor a significant carotid stenosis was found, then the territorial stroke was classified as one with undetermined cause. The aim of this study was to investigate WMLs in 3 groups of patients, namely those with small-vessel disease (i.e., lacunar stroke), with large-vessel discase (i.e., ternitorial stroke due to large-vessel atherosclerosis), and those with territorial stroke due to cardiac embolism. Therefore, patients with a specific stroke cause such as vasculitis, arterial dissection etc., were not included in this study.

Salent bran infaret was defined as a low-density area on the CT scan compatible with infarction but without a history of stroke, as taken from the patient's history, from family, on any other accessible information. Also, the stroke symptoms at study entry had to be anatomically incompatible with this infarct. Old infarcts can usually be distinguished from new ones because they are mone lyypodense, and there may be signs of surrounding tissue loss, like retraction of brain structures towards the infarct. Silent infarcts were also categorized as small deep or territorial. 
White matter lesions (WMLs) were defined as focal or diffuse hypodensities in the periventricular or deep white matter, not involving the cortex, and with ill-defined margins to distinguish them from infarction [168]. No effort was made to quantify the degree of white matter density in these different sites, as this might depend on the tuning of the CT scan.

\section{Patient population}

Of 999 consecutively registered patients, 39 patients were excluded from this $s t u d y, 37$ because a CT scan of the brain had not been performed, and 2 because the CT scan could not be retrieved. So, 960 patients entered this study. Median time between study entry and the CT" scan was 4 (range: 0-882) days. In eleven patients this period was more than 100 days: in seven patients 100-200, in two 200-300, in one 566, and in one 882 days. Despite this long delay between stroke and the time of CT, we entered these patients in our registry because we could verify their symptomatic stroke with a compatible lesion on CT. CT scans were reviewed for the presence and extensiveness of WMLs, and the number of (symptomatic as well as silent) small deep and territorial infarcts by 2 neurologists. Only those WMLs and infarcts on which both investigators agreed were registered.

\section{Statistical analysis}

We related the presence of WMLs to clinical variables by means of bivariate statistical analysis with crude odds ratios ((c)OR) with $95 \%$ confidence intervals (CI). Multivariate logistic regression analysis with adjusted odds ratios ((a)OR) determined the association of various subsets of clinical variables with presence of WMLs. Besides the vascular risk factors, the following clinical variables were included in various regression models: stroke subtype, presence of silent small deep or territorial infarcts, and Rankin (handicap) score at study entry. The Rankin scores were divided into 2 groups: functionally independent (Rankin $\leq 3$ ) or dependent (Rankin $=4$ or 5). Patients were categorized in 4 age-gromps: 64 years or younger, 65 to 71 years, 72 to 78 years, and older than 78 years. The 3 "higher-age" categories were compared with the youngest age. Haematocrit at admission was classified in 3 categories: low (men: $<0.411 / 1$, women: $<0.36$ ), normal (men: 0.41 0.51, women: 0.36-0.46), and high (men: $>0.51$, women: $>0.46)$. Patients with a low or high haematocrit were compared with those with normal walues.

\section{Results}

Table 4.1 shows the baseline characteristics and CT findings in the ischaemic stroke subgroups. Because the analyses showed no difference between the atherothrombotic subgroup of territorial stroke and the subgroup of territorial stroke with undetermined cause, the restllts are shown for these 2 groups combined. Median age was 72 (range: 24-96) yoars. 
Table 4.1: Baseline characteristics and CT findings in the three subgroups of stroke patients.

\begin{tabular}{|c|c|c|c|c|c|}
\hline \multicolumn{2}{|c|}{ Baseline characteristics } & \multirow{3}{*}{$\begin{array}{l}\text { Total } \\
N=960\end{array}$} & \multicolumn{3}{|c|}{ Symptomatic strake subgroups } \\
\hline & & & \multirow{2}{*}{$\begin{array}{c}\text { Lacunar } \\
N=332(35)\end{array}$} & \multirow{2}{*}{$\begin{array}{l}\text { Cardio-embolic } \\
N=213(22)\end{array}$} & \multirow{2}{*}{$\begin{array}{l}\text { Atherothrombotic/ } \\
\text { Undetermined cause } \\
\qquad N=41.5(43)\end{array}$} \\
\hline & & & & & \\
\hline \multirow[t]{4}{*}{ Age (years) } & $\leq 64$ & $240(25)$ & $98(30)$ & $26(12)$ & $116(28)$ \\
\hline & $65-71$ & $235(24)$ & $89(27)$ & $47(22)$ & $99(24)$ \\
\hline & $72-78$ & $252(26)$ & $89(27)$ & $55(26)$ & $108(26)$ \\
\hline & $>78$ & $233(24)$ & $56(17)$ & $85(40)$ & $92(22)$ \\
\hline \multicolumn{2}{|l|}{ Male gender } & $497(52)$ & $185(56)$ & $90(42)$ & $222(53)$ \\
\hline \multicolumn{2}{|c|}{ Hypertension } & $435(45)$ & $158(48)$ & $102(48)$ & $175(42)$ \\
\hline \multicolumn{2}{|c|}{ Diabetes mellitus } & $194(20)$ & $65(20)$ & $48(23)$ & $81(20)$ \\
\hline \multicolumn{2}{|c|}{ Ischaemic heart disease } & $250(26)$ & $67(20)$ & $71(33)$ & $112(27)$ \\
\hline \multicolumn{2}{|c|}{ COPD } & $97(10)$ & $39(12)$ & $23(11)$ & $35(8)$ \\
\hline \multicolumn{2}{|l|}{ Diunetics } & $277(29)$ & $83(25)$ & $88(41)$ & $106(26)$ \\
\hline \multirow[t]{3}{*}{ Haematocrit: } & low & $\mathbb{1 5 0}(16)$ & $38(11)$ & $45(21)$ & $67(16)$ \\
\hline & normal & $723(75)$ & $259(78)$ & $133(62)$ & $331(80)$ \\
\hline & high & $87(9)$ & $35(11)$ & $35(16)$ & $17(4)$ \\
\hline \multicolumn{2}{|c|}{ Rankin $=4$ or 5} & $495(52)$ & $104(31)$ & $145(68)$ & $246(59)$ \\
\hline \multicolumn{2}{|c|}{ White matter lesions } & $235(24)$ & $96(29)$ & $46(22)$ & $93(22)$ \\
\hline \multicolumn{2}{|c|}{ Silent small deep infarcts } & $223(23)$ & $103(31)$ & $35(16)$ & $85(20)$ \\
\hline \multicolumn{2}{|c|}{ Sillent territorial infarcts } & $61(6)$ & $14(4)$ & $18(8)$ & $29(7)$ \\
\hline
\end{tabular}

COPD $=$ Chronic obstructive pulmonary disease.

Percentages between parentheses.

Patients with a cardio-mbolic stroke were sigmificantly older than patients with a lacunar or atherothrombotic stroke $\left(x^{2}\right.$-test: $\left.\mathrm{p}=0.00\right)$. The Rankin score showed that lacunar stroke patients were less disabled than those with a territorial stroke ( $\chi^{2}$-test: $\left.p=0.00\right)$. In 680 patients a noninvasive carotid study was performed, which showed a significant stenosis on the symptomatic side in $150(22 \%)$ patients: 25 (10\%) lacunar, 11 (10\%) cardio-embolic, and $114(37 \%)$ atherothrombotic stroke patients.

Both WMLs and silent, small deep infarcts were found frequently in all stroke patients, $24 \%$ and $23 \%$, respectively. Both were more frequent in the lacunar stroke subgroup (29\% and $31 \%$ respectively). Silent territorial infarcts were less frequent ( $6 \%$ of all patients). of patients with silent small deep infarcts $65 \%$ had only one such infarct. Multiple small deep infarcts (range: 1-8) occurred almost exclusively in lacunar stroke patients. 


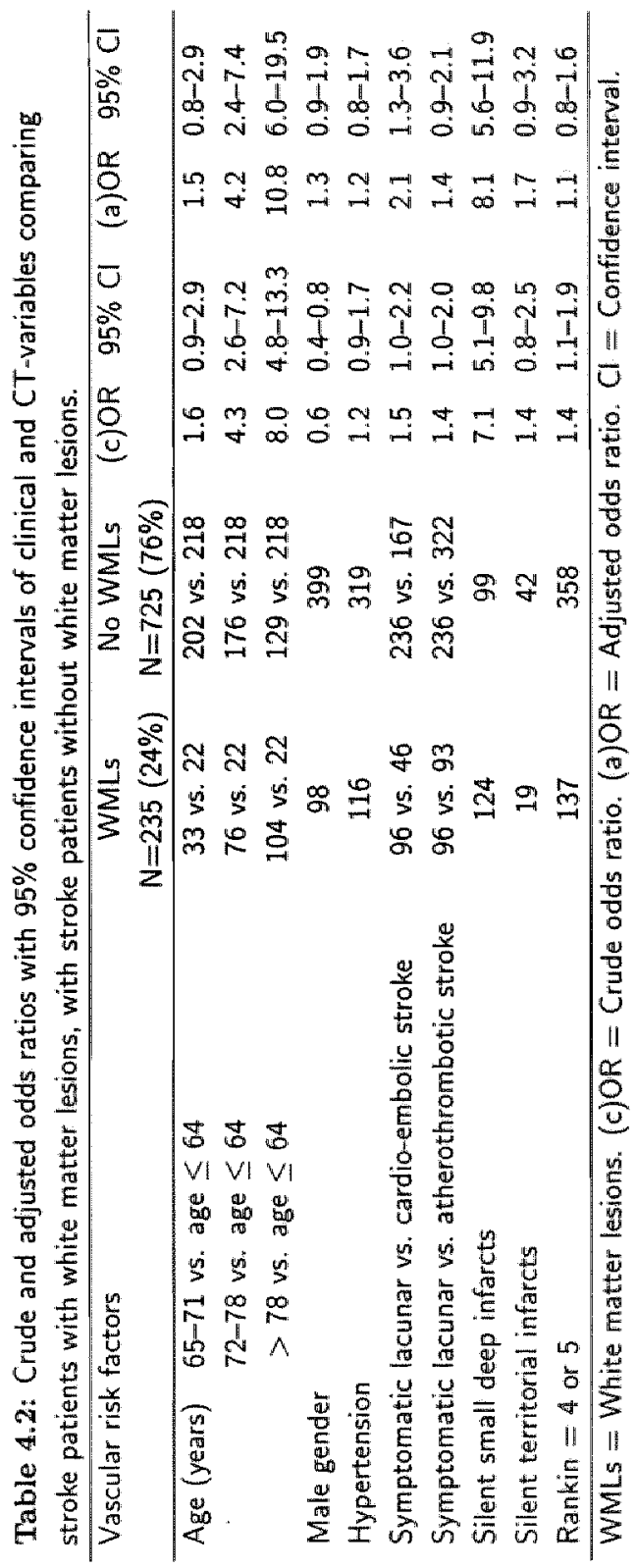




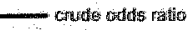

aidusted od dids ratio

age 65-71 vs, agle $\leq 64$

age $72-78$ vs. age $\leq 64$

age $>78$ vs. age $\leq 64$

malle gender

hypertentsion

symptomatic lacunar vs. cardio-embolic stroke

symptomatic lacunar vs. atherothrombotic stroke

sllent small cheep infarcts

silent territorial infarcts

Rarkin $=4$ or 5

\section{White matter lesions}

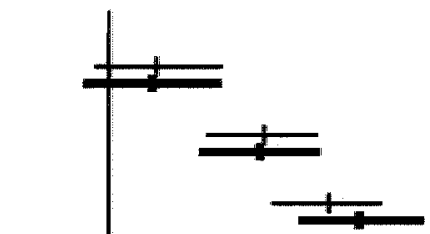

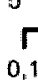
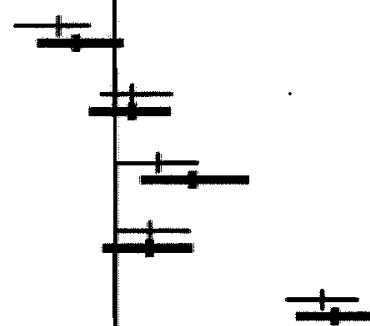

(n)

Figure 4.1: Crude and adjusted odds ratios with $95 \%$ confidence intervals of clinical and CT-variables comparing stroke patients with white matter lesions, with stroke patients without white matter lesions.

Table 4.2 and Figure 4.1 show crude and adjusted odds ratios with $95 \%$ confidence intervals comparing stroke patients with WMLs, with stroke patients without WMLs. WMLs were significantly associated with higher age (age $72-78$ vs. age $\leq 64$ : (a) OR $4.2,95 \% \mathrm{CI}$ 2.4-7.4; age $>78$ vs. age $\leq 64$ : (a)OR 10.8, 95\% CI 6.0-19.5). WMLs were not associated with the Rankin (handicap) score. WMLs were related to lacunar stroke (lacunar vs. cardio-embolic stroke ((a)OR 2.1, 95\% CI 1.3-3.6), lacunar vs. atherothrombotic stroke ((a)OR 1.4, 95\% CI 0.9-2.1), and to silent small deep infarcts ((a)OR 8.1,95\% CI 5.61.1.9). When we analyzed patients younger than 75 years with the same model, we found the same associations as we did in the analysis of all patients. In a separate multivariate regression analysis with a model including multiple small deep infarcts (defined as more than one symptomatic or silent, small deep infarct), age, gender, hypertension and Rankin score, we found that WMLs were strongly associated with both age, and multiple small deep infarcts ((a)OR 8.9, 95\% CI 5.7-13.9).

Tables 4.9,4.4, and 4.5 and Figures 4.2, 4.3. and 4.4 show crude and adjusted odds ratios with $95 \%$ confidence intervals comparing patients in each stroke subgroup with WMLs, with patients in each stroke subgroup without WMLs. Because all cardio-embolic 
Table 4.3: Crude and adjusted odds ratios with $95 \%$ confidence intervals of clinical and CT-variables comparing lacunar stroke patients with white matter lesions, with lacunar stroke patients without white matter lesions.

\begin{tabular}{lcccccc}
\hline Vascular risk factors & $\begin{array}{c}\text { WMLs } \\
N=96(29 \%)\end{array}$ & $\begin{array}{c}\text { No WMLs } \\
N=236(71 \%)\end{array}$ & $(\mathrm{c}) \mathrm{OR}$ & $95 \% \mathrm{Cl}$ & $(\mathrm{a}) \mathrm{OR}$ & $95 \% \mathrm{Cl}$ \\
\hline Age (yrs) $65-71$ vs. $\leq 64$ & 17 vs. 12 & 72 vs. 86 & 1.7 & $0.8-3.8$ & 1.4 & $0.6-3.4$ \\
$72-78$ vs. $\leq 64$ & 35 vs. 12 & 54 vs. 86 & 4.6 & $2.2-9.7$ & 4.4 & $1.9-10.3$ \\
$>78$ vs. $\leq 64$ & 32 vs. 12 & 24 vs. 86 & 9.6 & $4.3-21.3$ & 10.5 & $4.0-27.3$ \\
Male gender & 48 & 137 & 0.7 & $0.4-1.2$ & 0.9 & $0.5-1.6$ \\
Hypertension & 52 & 106 & 1.4 & $0.9-2.3$ & 1.5 & $0.8-2.6$ \\
Silent small deep infarcts & 63 & 40 & 9.4 & $5.4-16.1$ & 10.1 & $5.5-18.6$ \\
Silent territorial infarcts & 4 & 10 & 1.0 & $0.3-3.2$ & 0.7 & $0.2-2.7$ \\
Rankin = 4 or 5 & 40 & 64 & 1.9 & $1.2-3.2$ & 1.2 & $0.6-2.2$ \\
\hline WMLs $=$ White matter lesions. (c)OR $=$ Crude odds ratio. (a)OR $=$ Adjusted odds ratio. \\
Cl = Confidence interval.
\end{tabular}

stroke patients with WMLs were older than 65 years, the two youngest age-groups were taken together in the analysis. In all stroke subgroups we found significant associations of WMLs with higher age (lacunar: age $72-78$ vs $\leq 64$ (a) OR 4.4, 95\% CI 1.9-10.3, age $>78$ vs. $\leq 64$ (a) OR 10.5, 95\% CI 4.0-27.3; cardio-embolic: age $72-78$ vs. $\leq 71$ (a) OR 6.9 , $95 \%$ CI 1.8-26.8, age $>78$ vs. $\leq 71$ (a) OR $12.7,95 \%$ CI $3.5-46.4$; atherothrombotic: age $72-78$ vs. $\leq 64$ (a)OR $3.5,95 \%$ CI $1.5-8.2$, age $>78$ vs. $\leq 64$ (a)OR $10.9,95 \%$ Cl 4.5-26.5). WMLs were also related to silent small deep infarcts in all stroke subgroups (lacumar: (a)OR 10.1, 95\% CI 5.5-18.6; cardio-embolic: (a)OR 4.4, 95\% CI 1.9-10.3; atherothrombotic: (a)OR 8.6, 95\% CI 4.7-15.8). Furthermore, WMLs were associated with silent territorial infarcts in the atherothrombotic subgroup ( $(a) \mathrm{OR} 2.7,95 \%$ CJ 1.0 6.8).

\section{Discussion}

\section{Frequency of WMLs}

We found WMLs in $24 \%$ of our ischaemic strolke patients. In a similar study Jørgensen et al. [96] found WMLs in $15 \%$ of ischaemic stroke patients. In the study of Hijdra et al. [87] the prevalence of WMLs in ischaemic stroke patients was much higher (35\%), but this study may have suffered bias because only patients with a clinically relevant lesion on the CT scan were included. 


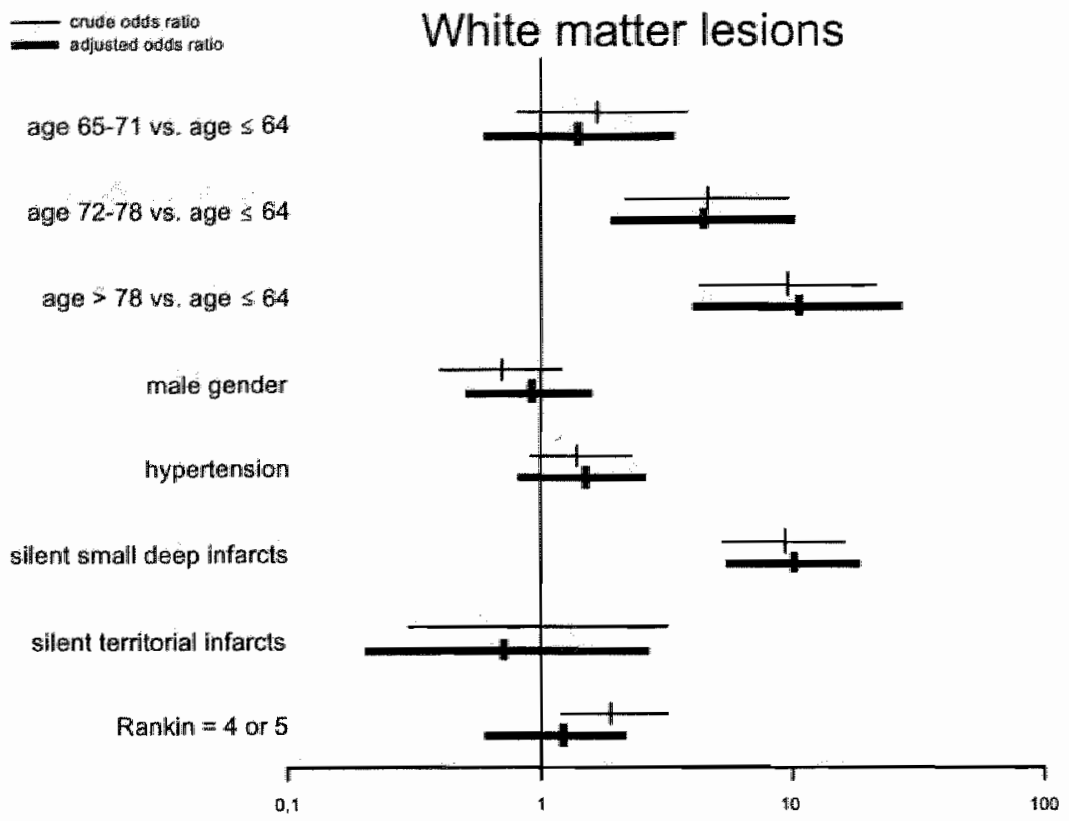

Figure 4.2: Crude and adjusted odds ratios with $95 \%$ confidence intervals of clinical and CT-variables comparing lacunar stroke patients with white matter lesions, with lacunar stroke patients without white matter lesions.

\section{Vascular risk factors}

Among all vascular risk factors we only found higher age to be associated with WMLs. Hypertension was not independently associated with WMLs in this study. Also in patients younger than 75 years we found no association of WMLs with hypertension. Previous studies found WMLs to be associated with various vascular risk factors: higher age $[4,30$, $32,37,81,87,96,113,122,171,193]$, hypertension $[4,30,32,112,122]$, use of diuretics [32], history of heart disease [30, 113], diabetes mellitus [193], and hypoxia [37]. Some authors found no relationship between hypertension and WMLs [96, 193]. Possibly, hypertension may not be identified as a discriminator among a population which already has a high frequency of hypertension and end-organ damage due to liypertension, such as stroke. Moreover, Liao et al. [112] found in a population-based study that the level of blood pressure is related to WMLs: patients with antihypertensive treatment who still had high blood pressure, had greater odds of WMLs than those with antihypertensive treatment with a normalized blood pressure. So, antihypertensive treatment in our stroke patients may have weakened the effect of hypertension as a risk factor. Breteler et al. [30] found the association 
Table 4.4: Crude and adjusted odds ratios with $95 \%$ confidence intervals of clinical and CT-variables comparing cardio-embolic territorial stroke patients with white matter lesions. with cardio-embolic territorial stroke patients without white matter lesions.

\begin{tabular}{|c|c|c|c|c|c|c|}
\hline Vascular risk factors & $\begin{array}{c}\text { WMLs } \\
N=46(22 \%)\end{array}$ & $\begin{array}{c}\text { No WMLs } \\
N=167(78 \%)\end{array}$ & (c)OR & $95 \% \mathrm{Cl}$ & (a)OR & $95 \% \mathrm{Cl}$ \\
\hline Age (yrs) $72-78$ vs. $\leq 71$ & 13 vs. 3 & 42 ws. 70 & 7.2 & $1.9-26.8$ & 6.9 & $1.8-26.8$ \\
\hline$>78$ vs. $\leq 71$ & 30 vs. 3 & 55 ws. 70 & 12.7 & $3.7-43.9$ & 12.7 & $3.5-46.4$ \\
\hline Male gender & 14 & 76 & 0.5 & $0.3-1.1$ & 0.7 & $0.3-1.6$ \\
\hline Hypertension & 21 & 81 & 0.9 & $0.5-1.7$ & 0.7 & $0.3-1.5$ \\
\hline Silent small deep infarcts & 16 & 19 & 4.2 & $1.9-9.0$ & 4.4 & $1.9-10.3$ \\
\hline Silent territorial infarcts & 5 & 13 & 1.4 & $0.5-4.3$ & 1.8 & $0.6-6.0$ \\
\hline Rankin $=4$ or 5 & 33 & 112 & 1.2 & $0.6-2.6$ & 0.9 & $0.4-2.0$ \\
\hline
\end{tabular}

between hypertension and WMLs only in subjects aged 65-74 years, not in older subjects. Their explanation for this fincling was that in the very old, the importance of elevated blood pressure for the risk of vascular disease seems to diminish or even reverse [25]. Since cardiovascular risk factors are all associated with increased mortality, very old survivors with these risk factors may form a selected group resistant to the damaging eflects of hypertension. Age may be a far more important risk factor in the elderly than hypertension.

\section{Association with silent territorial infarcts}

In the atherothrombotic subgroup WMLs were associated with silent territorial infarcts. No previous study found such association. Territorial infarcts may have caused Wallerian degeneration resulting in lower densities in the white matter [110]. Studies on WMLs in similar stroke populations as ours $[81,96]$, did not look into the association of symptomatic or silent infarcts with WMLs.

\section{Associations with lacunar stroke and multiple, usually silent small deep infarcts}

We found that WMLs were associated with symptomatic lacunar stroke, and even mor with silent small deep infarcts. This association was also found in a neurogeriatric pojulation [32], and in neurologically nondiseased elderly subjects [193]. Hijcira et al. [87], in a similar study regarding WMLs in ischaemic and haemorrhagic stroke patients, also showed that WMLs were related to small deep infarcts, but they did not differentiate between single symptomatic and multiple silent small dleep infarcts. 


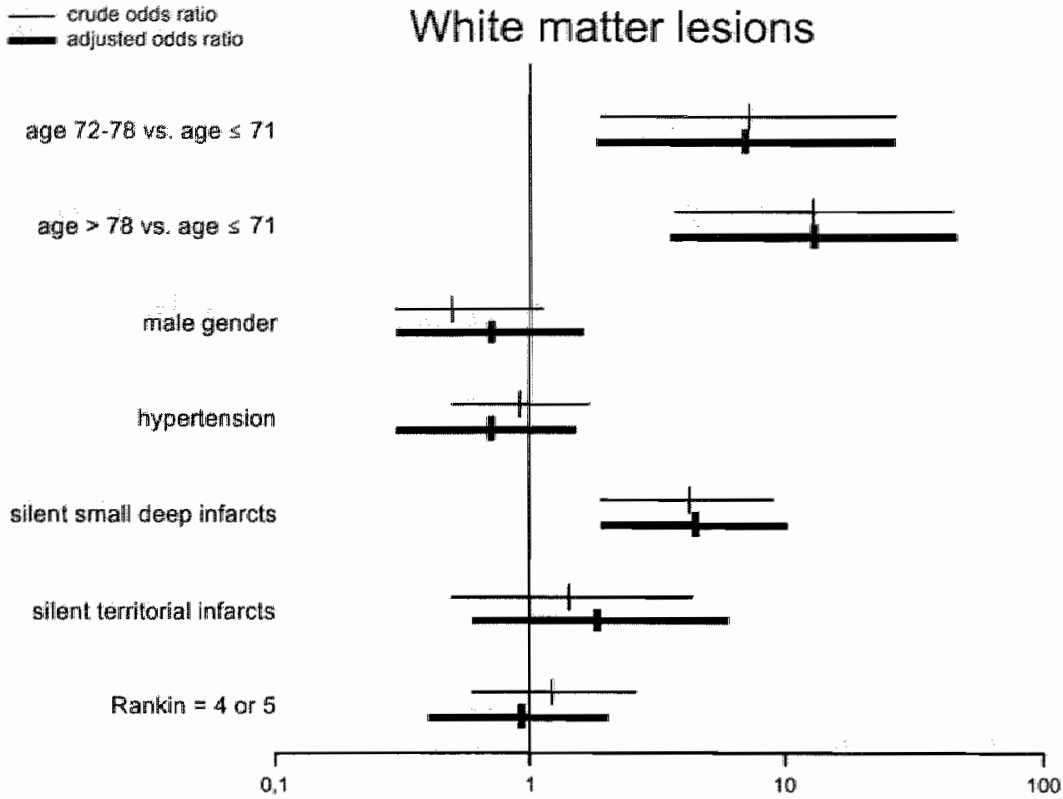

Figure 4.3: Crude and adjusted adds ratios with $95 \%$ confidence intervals of clinical and CT-variables comparing cardio-embolic territorial stroke patients with white matter lesions, with cardio-embolic territorial stroke patients without white matter lesions.

\section{Neuropathology}

Why are small deep infarcts, and especially silent ones, associated with WMLs? Neuropathologic studies of WMLs showed demyelination $[3,28,31,66,101,161,162,187]$, axonal loss $[31,187]$, dilated perivascular spaces $[3,161,187]$, gliosis $[3,7,28,31,161,162,187]$, arterioloschrosis $[3,7,31,64,66,101,161,187]$, and (small deep) infarcts $[7,28,31,161$, 187]. Although a mixture of pathologic changes is found in WMLs, many authors believe that arteriolosclerosis is the primary factor in WMLs $[3,7,28,31,162,187]$. The loss of myelin might simply be explained by the fact that white matter contains a Jot of myelin, in contrast with the grey matter in the basal ganglia. Therefore, ischaemia due to arteriolosclerosis in the white matter will lead to demyelination. Because in both small deep infarcts and WMLs arteriolosclerosis is found, this is thought to be the common pathological cause.

\section{Two distinct small deep infarct entities}

Pathological evidence, although scarce, points at arteriolosclerosis as the cause of multiple, usually silent small deep infarcts, whereas the somewhat larger, symptomatic ones are 
Table 4.5: Crude and adjusted odds ratios with $95 \%$ confidence intervals of clinical and CTvariables comparing atherothrombotic territorial stroke patients with white matter lesions. with atherothrombotic territorial stroke patients without white matter lesions.

\begin{tabular}{|c|c|c|c|c|c|c|}
\hline Wascullar risk factors & $\begin{array}{c}\text { WMLs } \\
N=93(22 \%)\end{array}$ & $\begin{array}{c}\text { No WMLs } \\
N=322(78 \%)\end{array}$ & (c)OR & $95 \% \mathrm{Cl}$ & (a)OR & $95 \% \mathrm{Cl}$ \\
\hline Age (yrs) $65-71$ ws $\leq 64$ & 13 vs. 10 & 86 vs. 106 & 1.6 & $0.7-3.8$ & 1.6 & $0.6-4.2$ \\
\hline $72-78$ ws. $\leq 64$ & 28 vs. 10 & 80 vs. 106 & 3.7 & $1.7-8.1$ & 3.5 & $1.5-8.2$ \\
\hline$>78$ vs. $\leq 64$ & 42 vs. 10 & 50 vs. 106 & 8.9 & $4.1-19.2$ & 10.9 & $4.5-26.5$ \\
\hline Male gender & 36 & 186 & 0.5 & $0.3-0.7$ & 0.6 & $0.4 \div 1.1$ \\
\hline Hypertension & 43 & 132 & 1.2 & $0.8-2.0$ & 1.2 & $0.7-2.1$ \\
\hline Silent small deep infarcts & 45 & 40 & 6.6 & $3.9-11.2$ & 8.6 & $4.7-15.8$ \\
\hline Silent territorial infarcts & 10 & 19 & 1.9 & $0.9-4.3$ & 2.7 & $1.0-6.8$ \\
\hline Rankin $=4$ or 5 & 64 & 182 & 1.7 & $1.0-2.8$ & 1.2 & $0.6-2.1$ \\
\hline
\end{tabular}

caused by microatheromatosis [34,58]. Also on clinical grounds one might argue that two distinct small deep infarct entities exist. In a study on 100 lacunar infarct patients Boiten and Lodder found that WMLs were associated with silent small deep infarcts [20]. The silent infarcts differed in location more often in the anterior limb of the internal capsule and in the caudate nucleus, less often in the posterior limb of the internal capsule), involved vascular territory (more often in the lateral and medial striate arteries territory, less often in the anterior choroidal artery territory), and volume (smaller) from the symptomatic infarcts. Furthermore, hypertension was more frequent in patients with multiple silent small deep infarcts, than in those with a single symptomatic lacnnar stroke. These findings were confirmed by Mast et a.. [127], who found multiple smal] deep infarcts, but not single ones, to be associated with hypertension and diabetes mellitus. Furthermore, cerebral blood How in the cerebral cortex was found to be significantly lower in patients with multiple small deep infarcts than in those with a single small desp infarct [133]. These. studies suggest that hypertension-associated arteriolosclerosis is the main cause of multiple (silent) small deep infarcts, which explains the association we found between WMLs and silent small deep infarcts.

\section{Vascularisation}

A further question is why arteriolosclerosis causes small deep infarcts in various deep areas and confluent lesions, which are not evident infarcts, in the regions supplied by the medullary penetrators. The basal ganglia and thalamus are supplied by deep perforating branches of the large cerebral arteries, such as the lenticulostriate, thalamoperforating, and 


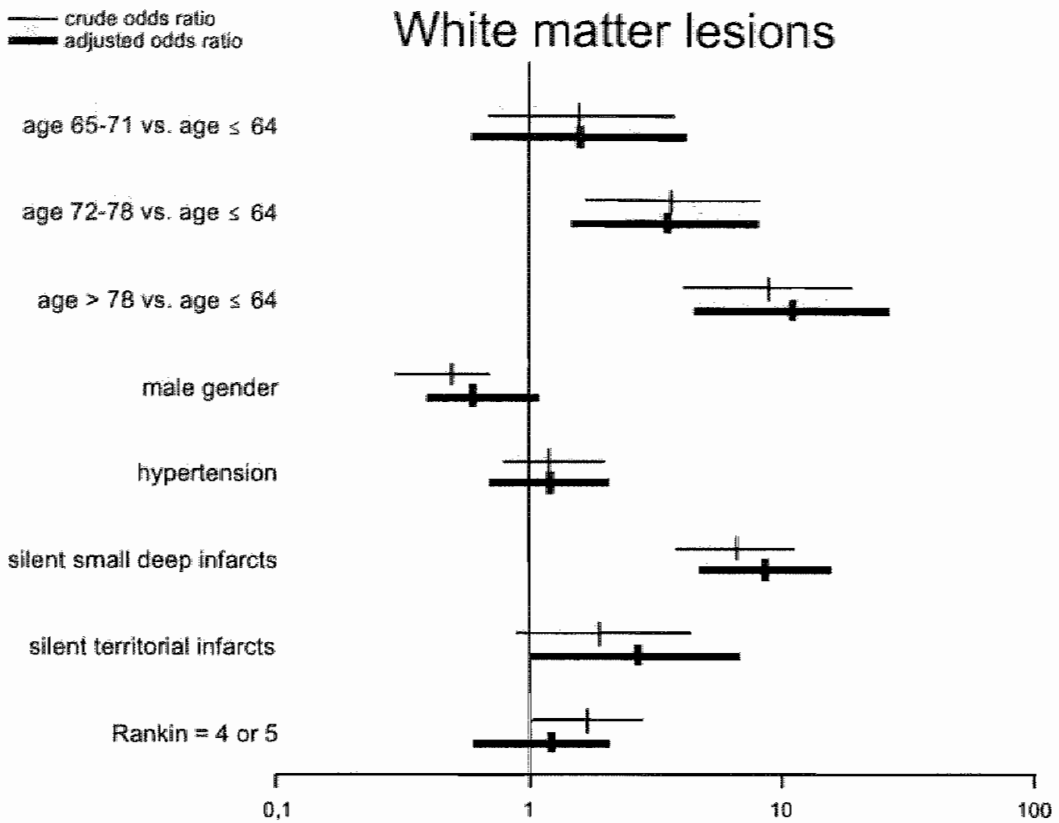

Figure 4.4: Crude and adjusted adds ratios with $95 \%$ confidence intervals of clinical and CT-variables comparing atherothrombotic territorial stroke patients with white matter lesions. with atherothrombotic territoriall stroke patients without white matter lesions.

anterior choroidal artery [67]. Functionally, these are endarteries, although anastomoses may exist $[69,123,157]$. The centrum semiovale is supplied by long medullary arteries arising from the leptomeningeal plexus, which in tum arises from cerebral surface branches of the muterior, middle, and posterior cerebral arteries $[64,140]$. Moody et a]. [135] found that these medullary arteries and their arterioles have exclusive territories that border smoothly on one wother, foming numerous small sequential contact zones with adjacent afferent arteriolat systems thronghont the whole depth of the white matter, without interdigitation. Howewer, Nelson et al. [140] studying fetal and neonatal brains, found interconnecting precapillary anastomotic channels in the cortex and white matter. They believed that these interconnections persist into adolescence. Whether these interconnecting channels also exist in older age is unknown. The basal ganglia have a greater capillary density than the white matter [135]. Terminal branches of the most lateral thalamic arteries and the lateral striate arteries of the basal ganglia border on medullary vessels in the lowest portion of the centrum semiovale. Considerable variation exists in the contributions of the anterior, middle, and posterior cerebral arteries to the blood supply of the lobar white matter and the basal ganglia [183]. So, the vasculature in the basal ganglia and thalamus, and in 
the white matter are similar as to the scarcity of anastomoses. However, thene are also major differences: in the white matter the capillary density is lower and consecuently the supplied territory per capillary larger, than in the basal gangha. Therefore, hypopenfusion might cause larger lesions in the white matter than in the basal ganglia.

\section{Cerebral metabolism and regional blood flow}

As grey matter metabolic rate is higher than that in white matter, basal ganglia metabolic rate is higher than that in the periventricular white natter region [135]. Areas with a higher metabolic rate have a higher regional cerebral blood flow (CBF), which makes these areas more vulnerable to ischaemia, e.g., during hypotension [190]. While the cerebral cortex shows evidence of damage with flow below $17 \mathrm{ml} / 100 \mathrm{~g} / \mathrm{min}$., flows of 6 to $8 \mathrm{ml} / 100 \mathrm{~g} / \mathrm{min}$. can be tolerated for 1 hour before evidence of infarction appears in deep white matter [190]. Do these differences in metabolism and CBF between basal ganglia and white matter explain why as a result of ischaemia small deep infarcts develop in one region and more confluent lesions in the other? PET-studies showed that WMLs were associated with a reduced CBF $[82,129]$, and reduced cortical metabolism $[42,82,172]$. However, SPECT-studies in general population showed no association between WMLs and $\mathrm{CBF}[38,104]$, whereas silent small deep infarcts were related to a significant decrease in mean regional CBF [104]. These studies can not answer the question whether decreased CBF caused the lesions, or the other way around. A PET-study in asymptomatic subjects with cerebrovascular risk factors showed that although resting grey matter CBF was not significantly correlated with the severity of WMLs, impaired autoregulation mechanisms such as lowered vasodilatory capacity, and decreased vasodilation compensatory to the fall. of cerebral perfusion pressure occurred in the cerebral cortex [93]. One could hypothesize that in these asymptomatic subjects disturbance of autoregulation causes WMLs by making the brain vulnerable to minor hypotensive episodes, whereas actual changes in CBF can not be measured yet. This hypothesis is supported by the association between WMLs and reduced compensatory mechanisms of the brain to cerebral perfusion pressure falls in patients with symptomatic carotid occlusion [92]. Although Fazekas et al. [52] found that carotid stenosis was associated with WMLs, we found in agrecnent with a recent large carotid endarterectomy trial [171], no association between WMLs and curotid stenosis. In another large carotid surgery trial an association was found between small infarcts in the white matter (so-called small centrum ovale infarcts) and carotid stenosis [21]. Possibly, carotid large-vessel disease is associated with small infarcts and not with more confluent lesions in the white matter. As no clear association exists between carotid stenosis and WMLs, carotid stenosis does probably not contribute to chronic impairment of white-matter-CBF, but in some patients it may cause (temporary) hypoperfusion. More likely, anteriolosclerosis causes impairment of white-matter-CBF-regulation, thereby causing WMLs. 


\section{Blood-brain barrier}

Caplan et al. [36] have hypothesized that WMLs may be due to hypertension and subsequent local fluid transudation and focal cerebrall edema, leading to loss of tissue with gliosis. Indeed Tomimoto et al. [181] found a dysfunction of the blood-brain barrier in ischaemic stroke patients with WMLs.

\section{Excitotoxicity}

Contrary to grey matter, white matter lacks glutaminergic synapses [54]. Glutamate plays a crucial role in excitotoxicity. Therefore, differences in the effects of excitotoxicity during ischaemia may also be involved in causing "incomplete infarction" in the white matter and infarcts in the grey matter. However, this has hardly been investigated.

In conclusion, we found that a considerable percentage of stroke patients have WMLs, which are associated with (especially sillent) small deep infarcts and higher age. This study supports the idea that WMLs and multiple, mostly silent small deep infarcts have the same vascular cause, namely arteriolosclerosis. However, because of differences between basal ganglia and white matter in vascular anatomy and $\mathrm{CBF}^{\circ}$ regulation, vascular insufficiency of the small vessels may lead to small infarcts in the basal ganglia, and to confluent areas of demyelination, axonal loss, dilated perivascular spaces, and gliosis in the white matter. 


\section{5}

Interobserver agreement in the assessment of cerebral atrophy on CT using bicaudate and Sylvian fissure ratios 


\section{Abstract}

Objectives: To assess and compare the interobserver variability of 2 cerebral-atrophy measures on computed tomographic (CT) scans.

Design: Measurements of the bicaudate ratio (BCR) and the Sylvian fissure ratio (SFR) on $20 \mathrm{CT}$ scans of ischaemic stroke patients by 3 investigators.

Results: The intraclass correlation coefficient of BCR measurements was 0.82 (95\% confidence interval (CI) $0.75-0.94$ ), and of SFR measurements 0.69 (95\% CI $0.57-0.89$ ). The range of pairwise calculated Pearson correlation coefficients was smaller in the measurements of the BCR $(0.89$ to 0.92$)$, than in the SFR measurements $(0.66$ to 0.84$)$.

Conclusions: The interobserver agreement of the BCR measurements was excellent and that of the SFR measurements moderate. 


\section{Introduction}

Cerebral atrophy may significantly contribute to cognitive impaiment $[29,71,98,115$, $150,176]$. Many ways of measuring cerebral atrophy on CT have been used $[70,128,158]$. Only a few studies reported on interobserver agreement in measuring cerebral atroplyy 189 , 108, 109], but none investigated the bicaudate ratio (BCR) or the Sylvian fissure ratio (SFR) which we often use to quantify the degree of cerebral atrophy. However, despite the absence of data on interobserver variability of the BCR, major decisions, such as shunting hydrocephalus in subarachnoid haemorthage patients, may partily depend on the value of the BCR [184]. Because we wanted to study the relationship between cerebral atrophy and white matter lesions (see Chapter 6), we first determined the interobserver agreement in measuring the BCR and SFR.

\section{Patients and methods}

Patients were registered at the University Hospital of Mastricht between July 1987 and January $1994 \mathrm{in}$ a prospective registry of all patients with a first-ever supratentorial brain infarct with symptoms lasting longer than 24 hours. From the brain CT scans of 999 registered patients, $20 \mathrm{CT}$ scans were randomly selected. Brain CT scans were performed with the scanning plane parallel to the orbitomeatal line, with consecutive $10 \mathrm{~mm}$ slices. In some patients the orbitomeatal scanning plane could not be used because of their bad medical condition or restlessness. To measure cerebral atrophy we used 2 linear measurements: (1) as measure of internal cerebral atrophy we used the bicaudate ratio (BCR), which was measured at the level that most prominently depicted the heads of the caudate nuclei. The $\mathbb{B C R}$ is the minimal distance between the caudate indentations of the frontal homs divided by the distance between the inner tables of the skull along the same line [70]. (2) As measure of external cerebral atrophy we chose the Sylwian fissure ratio ( $\mathrm{SFR}$ ), which is the average of the 2 maximal Sylvian fissure widths taken from the CT slice showing the widest Sylvian fissures, divided by the transpineal coronal inner table diameter [70]. To increase reliability of the measurements, the CI scans were projected on the wall with an oxertiead. projector, with a 10-fold magnification. The measurements of the BCR and $\mathrm{SFR}$ as defined above were practised in a few CT scans by 3 investigators together. Subsequently, the 3 investigators independently measured both ratios in 20 CI scans.

\section{Statistical analysis}

We assessed the interobserver agreement between the 3 investigators of the BCR and SFR. by means of intraclass correlation coefficients with $95 \%$ confidence intervals (CI), computed by oneway analysis of variance (ANOVA) [166]. Pearson corratation coeficients were computed to assess the interobserver agreement between all pairs of investigators. 
To detect significant differences in interobserver agreement between the pairs of investigators, the Pearson conrelation coefficients were tested taking into account their mutual dependence [24].

\section{Results}

The intraclass correlation coefficient of $\mathrm{BCR}$ measurements was 0.82 (95\% CI 0.75-0.94), and of SFR measurements $0.69(95 \%$ CI $0.57-0.89)$.

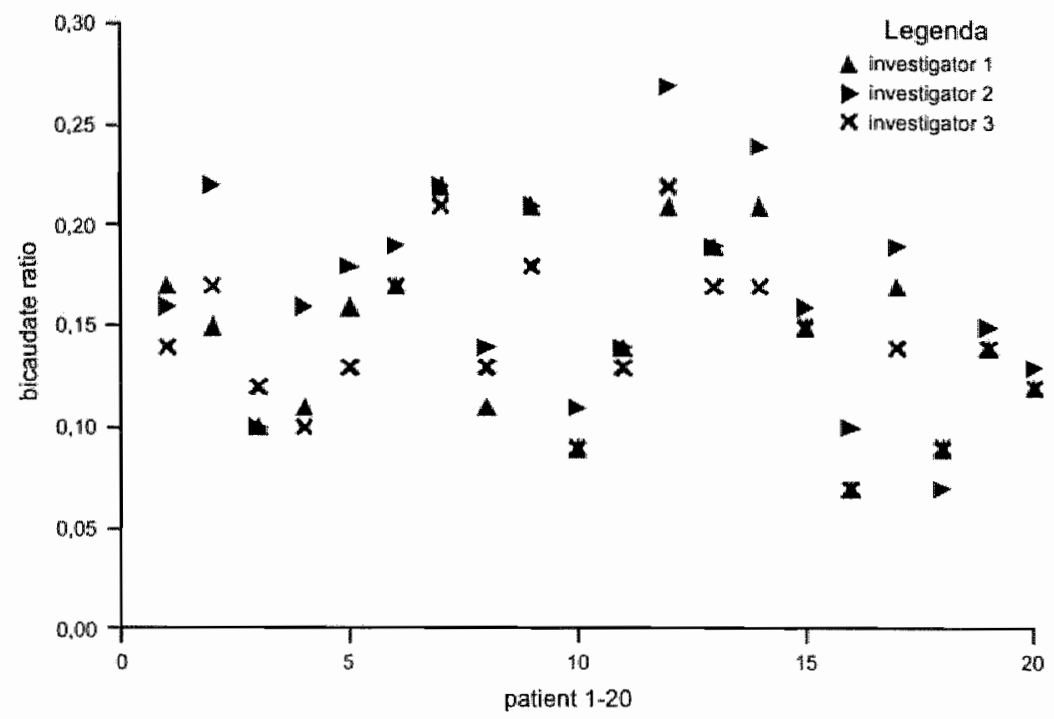

Figure 5.1: Distribution of the bicaudate ratio in the measurements of 3 investigators.

Figures $5 . t$ and 5.2 show the distribution of the BCR and of the SFR, respectively, as measured by the 3 investigators. In Table 5.1 the Pearson correlation coefficients comparing all pairs of investigators in measuring cerebral atroplyy are listed. The range of pairwise calculated Pearson correlation coefficients was smaller in the measurements of the BCR (0.89 to 0.92), than in the SFR measurements (0.66 to 0.84). The correlation coefficients of the measurements of investigator 1 and 3 were for both atrophy measures higher than those in the other pairs of investigators, but these differences in interobserver agreement between the pairs of investigators were not statistically significant. 


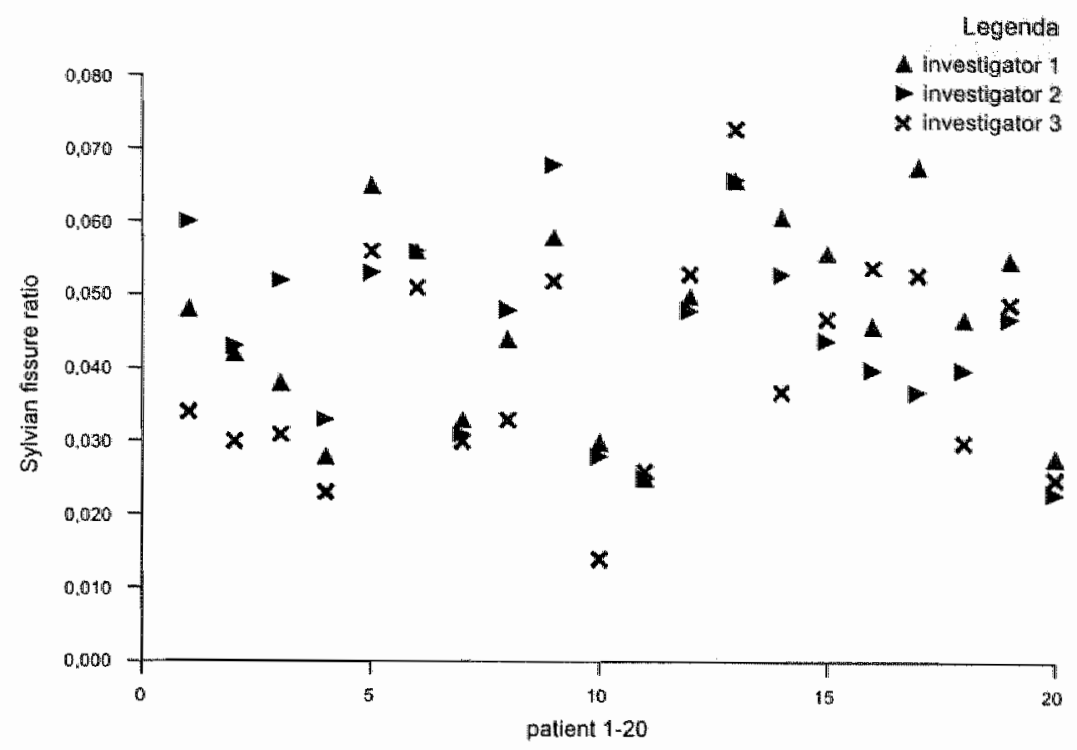

Figure 5.2: Distribution of the Sylvian fissure ratio in the measurements of 3 inwestigators.

\section{Discussion}

We found an excellent interobserver agreement in the measurement of the BCR and a moderate agreement in the measurement of the SFR. The Sylvian fissure was visible on several CT slices with different widths on each slice. This may have increased interobserver variability by measuring the SFR on different CT slices by the 3 investigators. The finding that there was no significant difference in interobserver agreement between all pairs of investigators may be due to the small number of measurements.

We decided only to use the BCR as measure of internal atrophy (see Chapter 6), and not to measure external cerebral atrophy by means of the SFR, firstly, because the interobserver agreement of the BCR compared to that of the SFR was higher. Moreover, Coffey et al. [39] found in a wolumetric magnetic resonance imaging (MRI) study that ventricular enlargement provides a more sensitive index of declining brain volume than does cortical atrophy.

We are not aware of an earlier study on interobserver agreement in the measument. of the BCR and SFR on CT. Only a few CT studies have been published on interobserver variability quantifying atrophy. For subjectively quantifying cerebral atrophy a low kappa $(\kappa)$ of 0.24 [109], and of 0.55 \$89] was found. Furthermore, a $\kappa$ of 0.59 was found for the subjective rating of type (cortical/subcortical) of atrophy [109]. The interobserver correlation in subjective evaluation of Sylvian sulci on CT was in the study of Lee et al. [108] 
Table 5.1: Pearson correlation coefficients comparing all pairs of investigators in measuring cerebral atrophy.

\begin{tabular}{|c|c|c|c|}
\hline \multirow[t]{2}{*}{ Cerebral-atrophy measures } & \multicolumn{3}{|c|}{ Pearson correlation coefficient } \\
\hline & Investigator 1 and 2 & Investigator 1 and 3 & Investigator 2 and 3 \\
\hline Bicaudate ratio & 0.89 & 0.92 & 0.89 \\
\hline Sylwian fissure ratio & 0.72 & 0.84 & 0.66 \\
\hline
\end{tabular}

not significant. Stabl et al. [167] assessed the degree of atrophy on CT subjectively, because an interobserver study of 60 normal CT scans did not produce reliable measurements. They do not mention an interobserwer agreement on this subjective method. The interobserver agreements we found in objective measurements of the BCR and the SFR were clearly higher than in these studies which used subjective methods to quantify cerebral atrophy.

Apart from interobserver variability, possible errors in linear measurements of atrophy on CT depend on thickness (partial volume effect) and the interwal of the slices [158]. Other methods have been used to measure cerebral atrophy on CT [158], such as planimetric methods, direct calculation of ventricle volume, and computed methods. Which method is most suitable and sufficiently operational for research remains unstudied.

With MRI scans slightly better interobserver agreements $(\kappa=0.48-0.67)$ in subjective quantification of cerebral atrophy were found $[148,163]$. Measurements of regional brain volume on MRI are highly reliable, with intraclass correlation coefficients for interrater reliability of $0.88-0.99$, and for intrarater reliability of $0.93-0.99$ [39].

Our study can not provide the normal values of the BCR and SFR. Others [184] combined two studies $[46,128]$ on $\mathrm{BCR}$ measurements in neurologically healthy individuals to derive upper limits for normal values (95th percentile) in several age-groups, but did

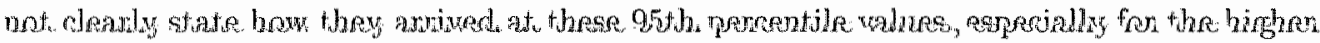
age-group (age $>70$ years). On the other hand, no better estimations of normal BCR. values are presently known.

In conclusion we found that the interobserver agreement of the $\mathrm{BCR}$ on $\mathrm{CT}$ in our stroke patients was excellent, and that of the SFR moderate. No accurate normal values of these atrophy measurements exist. 
6

Cerebral ventricular enlargement in stroke patients is not specifically associated with either small- or large-vessel disease 


\section{Abstract}

Objectives: To investigate whether in ischaemic stroke patients cerebral atrophy, as measured by the degree of ventricular enlargement, is associated with presence and site of white matter lesions (WMLs), stroke subtype, or silent brain infarcts.

Design and Patients: (1) Ventricular enlargement was measured with the bicaudate ratio (BCR) on the computed tomographic (CT) scans of 917 patients with a first-ever supratentorial ischaemic stroke. Linear regression analysis determined the association of vascular risk factors and $\mathrm{CT}$ variables with the BCR. (2) CT scans of 954 first-ever supratentorial ischaemic stroke patients were reviewed for presence of deep or periventricular WMLs. By means of multivariate logistic regression analysis we determined the associations of vascular risk factors and CT variables with deep or periventricular WMLs.

Results: Ventricular enlargement was associated with higher age, male gender, use of diuretics, WMLs, and with silent small deep and territorial infarcts. Both periventricular and deep WMLs were associated with higher age, silent small deep infarcts, and with lacunar stroke compared with cardio-embolic stroke.

Conclusions: (1) As ventricular enlargement in ischaemic stroke patients is associated with WMLs and silent small deep and territorial infarcts, we conclude that ventricular enlargement is merely due to tissue loss and not specifically associated with either smallor large-vessel disease. (2) Deep and periventricular WMLs had similar risk factor profiles and were both related to ventricular enlargement, which points at a similar, presumably vascular, pathogenesis. 


\section{Introduction}

Cerebral atrophy is a clinically important finding as it is related to cognitive impairment $[29,71,98,115,150,176]$. Several studies, in elderly $[29,79,102,122,193]$, hypertensive $[159,165]$, demented [115], and stroke patients $[81,86,116,147,150,176]$, pointed at hypertension as a risk factor for cerebral atrophy. Furthermore, vascular cerebral lesions such as symptomatic stroke, multiple cerebral infarcts on neuroimaging, and white matter lesions (WMLs) were associated with cerebral atrophy. The degree of cerebral atrophy in stroke patients may depend on the underlying vascular cause, such as small- or largevessel disease, or cardiac embolism. Such a relationship could give more insight, although indirectly, into the pathogenesis of cerebral atrophy and would stress the importance of lowering the risk of stroke recurrences in specific stroke subgroups. Therefore, the first objective of this study was to study cerebral atrophy in a large stroke population, focusing on associations with vascular risk factors, CT findings, and clinical stroke subtype.

Cerebral ventricular enlargement may especially be associated with periventricular hypodensities on CT in the syndrome of normal pressure hydrocephalus $[56,155]$. Such hypodensities are thought to be the result of leakage of cerebrospinal fluid (CSF) into the adjacent brain parenchyma, whereas WMLs in stroke patients are more likely the result of small-vessel disease of the white matter arterioles $[31,64,65,187]$. Consequently, an eventual association between ventricular enlargement and periventricular WMLs could point at the presence of normal pressure bydrocephalus among stroke patients. Testing this ly. pothesis we compared vascular risk factor profiles of patients with deep or periventricular WMLs to gain indirect clnes pointing at the alleged distinct pathogenesis in these two types of WMLs.

\section{Patients and methods}

Patients were registered at the University Hospital of Maastricht between July 1987 and January 1994 in a prospective registry of all patients with a first-ever supratentorial brain infarct with symptoms lasting longer than 24 hours, admitted or visiting the out,patient clinic. Routine investigations included standard blood tests, electrocardiogram, chest Xray, CT scan of the brain, and noninvasive carotid studies. Echocardiography, 24-hour ECG monitoring, and cerebral angiography were done in selected cases.

\section{Definitions}

The following possible vascular risk factors were recorded: age, gender, hypertension. (known hypertension, or at least 2 separate bjood pressure recordings of higher than $160 / 90 \mathrm{mmHg}$ before or at least 1 week after stroke), diabetes mellitus (known cliabetes mellitus, or fasting serumglucose higher than $7 \mathrm{mmol} / \mathrm{l}$, or at postprandial serumglncose 
higher than II mmol/1, both on at least 2 separate occasions), haematocrit at stroke onset, history of iscliaemic heart disease (myocardial infarction, angina pectoris), history of chronic obstructive pulmonary disease (COPD), cardiac source of embolism (atrial fibrillation, mitral stenosis, prosthetic aortic or mitral valve, recent myocardial infarction (within 6 weeks preceding stroke), endocarditis, cardiomyopathy, left ventricular aneurysm, intraventricular thrombus), use of diuretics prior to stroke, and significant (more than 50\%) carotid stenosis ipsilateral to the symptomatic stroke.

Lacunar stroke was defined as an acute symptomatic stroke syndrome with a CT lesion compatible with occlusion of a single perforating artery, i.e., a small, subcortical, sharply marginated hypodense lesion with a diameter smaller than $20 \mathrm{~mm}$ (small deep infarct), or in case of a specific lacunar syndrome (unilateral motor and/or sensory symptoms and signs that completely involve at least 2 of 3 body parts (face, arm, and leg) without disturbance of conscionsness or language, visual field defect or other signs of cortical dysfunction) when the $\mathrm{CT}$ scan showed no specific lesion.

Territorial stroke was defined (1) as an acute stroke syndrome with CT findings compatible with infarction involving the cortex, or (2) when no specific lesion was visible on CT, as a clinically identified cortical syndrome consisting of unilateral motor and/or sensory symptorns and signs in combination with signs of cortical dysfunction with or without visual field defect, or as incomplete involvement of 2 body parts, or as isolated monoparesis [16], or as isolated cortical dysfunction (usually dysphasia). Patients with a large subcortical infarct were included in this group because of similar pathogenesis $[18,21]$. By presumed stroke cause, 3 territorial stroke subtypes were discerned: cardio-embolic, atherothrombotic, and territorial stroke with undetermined cause. Cardio-embolic territorial stroke was defined as a territorial stroke in the presence of a cardiac source of embolism. Atherothrombotic stroke was defined as a territorial stroke in the presence of a significant carotid stenosis. If neither a cardiac source of embolism nor a significant carotid stenosis was found, then the territorial stroke was classified as one with undetermined cause. Because the analyses showed no difference between the atherothrombotic subgroup of territorial stroke, and that with undetermined cause, the results are shown for these 2 groups combined. The aim of this study was to investigate ventricular enlargement as measure of cerebral atrophy, and WMLs in 3 groups of patients, namely those with small-vessel disease (i.e., lacunar stroke), with large-vessel disease (i.e., territorial stroke due to large-vessel atherosclerosis), and those with territorial stroke due to cardiac embolism. Therefore, patients with a specific stroke cause such as vasculitis, arterial dissection etc., were not included in this study.

Silent brain infarct was defined as a low-density area on the CT scan compatible with infarction but without a history of stroke, as taken from the patient's history, from family, or any other accessible information. Also, the stroke symptoms at study entry had to be anatomically incompatible with this infarct. Old infarets can usually be distinguished 
from new ones because they are more hypodense, and there may be signs of surrounding tissue loss, like retraction of brain structures towards the infarct. Silent infarcts were also categorized as small deep or territorial.

White matter lesions (WMLs) were defined as focal or diffuse hypodensities in the periventricular or deep white matter, not involving the cortex, and with ill-defined margins to distinguish them from infarction [168]. Presence of WMLs around frontal or occipital horns, or in the centrum semiovale were rated separately. Patients with WMLs were divided in 2 subgroups: (1) patients with WMLs in the centrum semiovale with or without WMLs around frontal or occipital horns (deep WMLs), and (2) patients with WMLs limited to the area around the frontal or occipital horns (periventricular WMLs). No effort was made to quantify the degree of white matter density in these different sites as this may depend on the tuning of the CT scan.

\section{CT analysis}

CT scans were performed with the scanning plane parallel to the orbitomeatal line, with consecutive $10 \mathrm{~mm}$ slices. In some patients the orbitomeatal scanning plane could not be used because of their bad medical condition or restlessness. For the atrophy-study we assessed ventricular enlargement by means of the bicaudate ratio (BCR), which was measured on the CT slice that most prominently depicted the heads of the caudate nuclei (see Chapter 5). The BCR is the minimal distance between the caudate indentations of the frontal horns divided by the distance between the inner tables of the skull along the same line [70]. Furthermore, the CT scans were reviewed for presence and extensiveness of WMLs, and number of (symptomatic as well as silent) small deep and territorial infarcts by 2 neurologists. Only those WMLs and infarcts on which both neurologists agreed were registered.

\section{Patient population}

Of 999 consecutively registered patients, 37 patients were excluded because a CT scan of the brain had not been performed. Of the remaining 962 patients 45 were excluded for the first part of this study (measuring ventricular enlargement as measure of cerebral atrophy): in 34 patients the CT scan could not be retrieved, in 6 patients the BCR could not be measured because of eclema caused by the ischaemic stroke, and in 5 patients not all vascular risk factors were known. So, 917 patients entered the atrophy-study.

For the second part of the study (studying the vascular risk factors leading to deep or periventricular WMLs) 8 of the 962 patients were excluded: 2 because the CT scan could not be retrieved, and 6 because not all vascular risk factors were known. So, 954 patients entered the WML-study. Of all patients included in the Maastricht Stroke Registry CT scans are routinely examined for infarcts and WMLs. The atrophy-measurements were done at a later stage. This explains why more CT scans could not be retrieved in the 
atrophy-study.

Median time beween study entry and CT scan was 5 days for the atrophy-study, and 4 days for the WML-study (range: $0-882$ ). In respectively ten and eleven patients this period was more than 100 days: in six and seven respectively $100-200$, in two 200-300, in one 566, and in one 882 days. Despite this long delay between stroke and the time of CT, we entered these patients in our registry becanse we could verify their symptomatic stroke with a compatible lesion on CT.

\section{Statistical analysis}

For the atrophystudy, linear regression analysis, in which the BCR was the dependent variable, determined the association of the $B C R$ with various subsets of clinicall and $C T$ variables.

For the WML-study, we related presence of deep and periventricular WMLs to clinical and $C T$ variables by means of bivariate statistical analysis with crude odds ratios ((c)OR) with $95 \%$ confidence intervals (CI). Multivariate logistic regression analysis with adjusted odds ratios ((a)OR) determined the association of various subsets of clinical and CT wariables with presence of deep or periventricular WMLs.

Patients were categorized in 4 age-groups: 64 or younger, 65 to 71,72 to 78 , and older than 78 years. The 3 "higher-age" categories were compared with the youngest age. Haematocrit at admission was classified in 3 categories: low (men: $<0.41 \mathrm{l} / \mathrm{l}$, women: $<0.36$ ), normal (men: 0.41-0.51, women: $0.36-0.46$ ), and high (men: $>0.51$, women: $>0.46$ ). Patients with low and high haematocrit were compared with those with normal valwes. The Rankin (handicap) score at study entry was dichotomized in 2 groups: functionally independent (Rankin $\leq 3$ ) or dependent (Rankin $=4$ or 5$)$.

\section{Results}

\section{Ventricular enlargement as measure of cerebral atrophy}

Figure 6.I depicts the distribution of the BCR in all stroke patients. The median value of the BCR was 0.14 (range: $0.04-0.32$ ). The distribution of the BCR in this stroke population was fairly normal. In Figure 6.2 the mean BCR is depicted in all age-groups. This shows the gradual increase of the BCR with increasing age. In patients younger than 31 years the $B C R$ was relatively high. However, this group consisted only of 5 patients.

Table 6.1 shows the baseline characteristics and Cr findings in the 3 subgroups of stroke patients in the atrophy-study. Median age was 72 (range: 24-95) years. Patients with a cardio-embolic stroke were significantly older than patients with a lacunar or atherothrombotic stroke ( $\chi^{2}$-test: $p<0.001$ ). In 652 patients a noninvasive carotid study was performed, which showed a significant stenosis on the symptomatic side in 147 (23\%) patients: 25 $(10 \%)$ lacunar, 11 (11\%) cardio-embolic, and $111(37 \%)$ atherothrombotic stroke patients. 


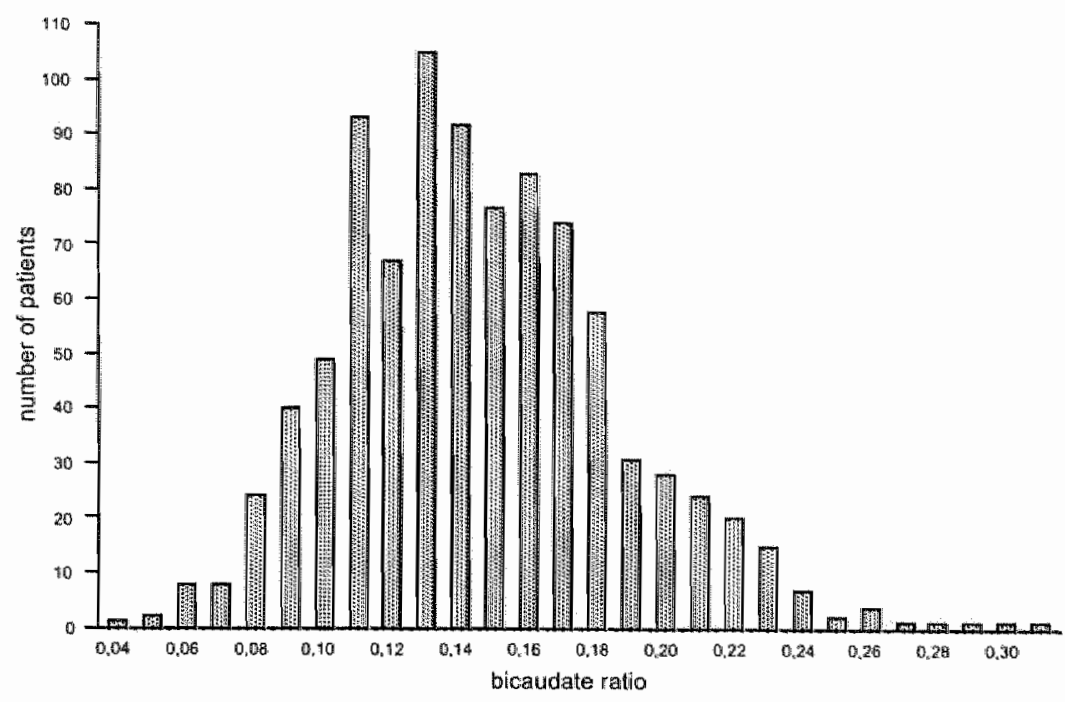

Figure 6.1: Distribution of the bicaudate ratio in 917 ischaemic stroke patients.

Table 6.2 and Figure 6.3 show the results of linear regression analysis with the BCR as dependent variable. Among the clinical variables higher age (age 65-71 vs. $\leq 64$ : regression coefficient $(B)=0.014,95 \%$ CI $0.008-0.021$; age $72-78$ vs. $\leq 64: B=0.032,95 \%$ CI $0.026-$ $0.039 ;$ age $>78$ vs. $\leq 64: B=0.038,95 \%$ CI $0.030-0.045)$, male gender $(B=0.014,95 \%$ CI $0.009-0.019)$, and use of diuretics $(B=0.006,95 \% \mathrm{CI} 0.000-0.011)$ were associated with a higher BCR Of the CT variables WMLs ( $B=0.013,95 \%$ CI $0.007-0.019)$, silent small deep infarcts $(B=0.006,95 \%$ CI $0.000-0.012)$, and silent territorial infarcts $(B=0.018,95 \% \mathrm{CI}$ 0.008-0.027) were associated with a higher BCR. The type of symptomatic stroke did not influence the BCR significantly. In another linear regression model we added deep and periventricular WMLs separately as risk factor. Both types of WMLs were associated with a higher BCR (deep: $B=0.012,95 \%$ CI $0.005-0.020$; periventricular: $\mathrm{B}=0.014,95 \% \mathrm{CI}$ $0.006-0.022)$.

\section{Deep and periventricular WMLs}

In Table 6.3 the baseline characteristics and CT findings in the 3 subgroups of stroke patients in the WML-study are listed. Median age was 72 (range: 24-96) years. Patients with a cardio-embolic stroke were significanty older than patients with lacunar or atherothrombotic stroke ( $x^{2}$-test: $\left.p=0.00\right)$. In 676 patients a noninwasive carotid study was performed, which showed a significant stenosis on the symptomatic side in 149 (22\%) patients: 25 (10\%) lacumar, 11 (10\%) cardio-embolic, and $113(37 \%)$ atherothrombotic stroke patients. 


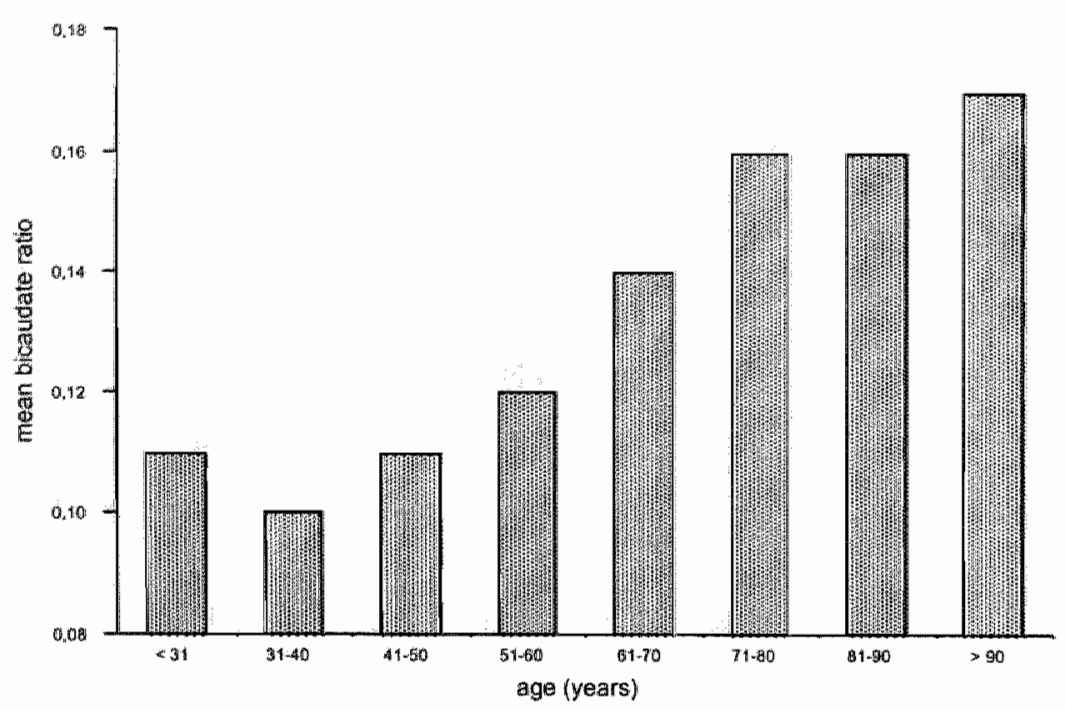

Figure 6.2: Bicaudate ratio distribution in age-groups.

Table 6.4 and Figure 6.4 show crude and adjusted odds ratios with $95 \%$ confidence intervals comparing patients with deep WMLs (WMLs in the centrum semiovale with or without WMLs around frontal or occipital horns) with those without WMLs, and patients with periventricular WMLs (WMLs limited to the area around frontal or occipital horns) with those without WMLs. Both WML-subgroups were associated with higher age (deep WMLs: age $72-78$ vs. $\leq 64$ (a)OR $5.0,95 \%$ CI $2.3-10.8$, age $>78$ vs. $\leq 64$ (a)OR 12.4 , $95 \%$ CI 5.6-27.7; periventricular WMLs: age $72-78$ vs. $\leq 64$ (a) OR $3.4,95 \%$ CI $1.6-7.1$, age $>78$ vs. $\leq 64$ (a)OR $9.2,95 \%$ Cl 4.3-19.6), with silent small deep infarcts (deep WMLs: (a)OR $7.4,95 \%$ CI 4.6-12.0; periventricular WMLs: (a)OR 8.4, 95\% Cl 5.2-13.3), and with lacunar stroke compared with cardio-embolic stroke (deep WMLs: (a)OR 2.2, 95\% CI 1.1.4.2; periventricular WMLs: (a)OR 2.3, 95\% CI 1.2-4.3). Periventricular WMLs were also related to lacunar stroke compared with atherothrombotic stroke ((a)OR 1.9, $95 \%$ Cl $1.1-3.2)$. Finally, deep WMLs were less strongly associated with male than female gender $((a)$ OR $0.6,95 \%$ Cl $0.3-0.9)$.

\section{Discussion}

\section{Cerebrall atrophy and vascular risk factors}

In our study ventricular enlargement as measure of cerebral atrophy was related to higher age, male gender, and use of diuretics. Several authors $[39,75,80,86,122,147]$ also found the association with higher age and with male gender $[75,122]$. Unfortunately, 
Table 6.1: Baselime characteristics and CT findings in the 3 subgroups of stroke patients in the atrophy-study.

\begin{tabular}{|c|c|c|c|c|c|}
\hline \multicolumn{2}{|c|}{ Baseline characteristics } & \multirow{3}{*}{$\begin{array}{l}\text { Total } \\
\mathbb{N}=917\end{array}$} & \multicolumn{3}{|c|}{ Symptomatic stroke subgroups } \\
\hline & & & \multirow{2}{*}{$\begin{array}{c}\text { Lacunar } \\
N=320(35)\end{array}$} & \multirow{2}{*}{$\begin{array}{l}\text { Cardio-embolic } \\
\qquad N=196(21)\end{array}$} & \multirow{2}{*}{$\begin{array}{l}\text { Atherothrombotic/ } \\
\text { Undetermined caluse } \\
\qquad N=401 \text { (44) }\end{array}$} \\
\hline & & & & & \\
\hline \multirow[t]{4}{*}{ Age (years) } & $\leq 64$ & $231(25)$ & $96(30)$ & $25(13)$ & $110(27)$ \\
\hline & $65-71$ & $224(24)$ & $84(26)$ & $44(22)$ & $96(24)$ \\
\hline & $72-78$ & $242(26)$ & $86(27)$ & $50(26)$ & $106(26)$ \\
\hline & $>78$ & $220(24)$ & $54(17)$ & $77(39)$ & $89(22)$ \\
\hline \multicolumn{2}{|l|}{ Male gender } & $478(52)$ & $179(56)$ & $86(44)$ & $213(53)$ \\
\hline \multicolumn{2}{|l|}{ Hypertension } & $416(45)$ & $152(48)$ & $94(48)$ & $170(42)$ \\
\hline \multicolumn{2}{|c|}{ Diabetes mellitus } & $184(20)$ & $62(19)$ & $44(22)$ & $78(19)$ \\
\hline \multicolumn{2}{|c|}{ Ischaemic heart disease } & $240(26)$ & $63(20)$ & $68(35)$ & $109(27)$ \\
\hline \multicolumn{2}{|c|}{ COPD } & $93(10)$ & $39(12)$ & $20(10)$ & $34(8)$ \\
\hline \multicolumn{2}{|l|}{ Diuretics } & $261(28)$ & $80(25)$ & $78(40)$ & $103(26)$ \\
\hline \multirow[t]{3}{*}{ Haematacrit: } & low & $142(15)$ & $34(11)$ & $44(22)$ & $64(16)$ \\
\hline & normal & $691(75)$ & $251(78)$ & $120(61)$ & $320(80)$ \\
\hline & high & $84(9)$ & $35(11)$ & $32(16)$ & $17(4)$ \\
\hline \multicolumn{2}{|c|}{ Rankin $=4$ or 5} & $466(51)$ & $100(31)$ & $130(66)$ & $236(59)$ \\
\hline \multicolumn{2}{|c|}{ White matter lesions } & $228(25)$ & $95(30)$ & $44(22)$ & $89(22)$ \\
\hline \multicolumn{2}{|c|}{ Silent small deep infarcts } & $211(23)$ & $100(31)$ & $31(16)$ & $80(20)$ \\
\hline \multicolumn{2}{|c|}{ Silent territorial infarcts } & $58(6)$ & $14(4)$ & $17(9)$ & $27(7)$ \\
\hline
\end{tabular}

COPD $=$ Chronic obstructive pulmonary disease.

Percentages between parentheses.

use of alcohol, which is associated with cerebral atrophy $[141,147]$, could not be reliably registered in our patients. A possible higher alcohol consumption among men could explain the relationship with male gender, but this remains speculative.

We found no association between ventricular enlargement and hypertension. Two studies $[159,165,170]$ in which hypertensive patients without stroke were compared with normal control subjects, showed that ventricular enlargement was related to hypertsnsion. Hypertension may not be identified as discriminator among a stroke population, which already has a high frequency of hypertension and hypertensive end-organ damage.

In contrast with Manolio et al. [122], we found ventricular enlargement related to the $1 \mathrm{se}$ of diuretics. This finding is all the more surprising realizing that diuretics are sometimes used to diminish CSF production in hydrocephalus. One could speculate that dintetics lead to dehydration of the brain and thereby to ventricular enlargement. Especially in wiew of the connection between cerebral atrophy and dementia $[29,71,150,176]$, this 
Table 6.2: Linear regression coefficients with $95 \%$ confidence intervals of clinical and CT variables in relation to the bicaudate ratio as dependent wariable, in 917 stroke patients.

\begin{tabular}{|c|c|c|c|c|}
\hline \multicolumn{2}{|c|}{ Vascular risk factors } & \multirow{2}{*}{$\frac{B}{0.014}$} & \multirow{2}{*}{$\frac{95 \% \mathrm{Cl}}{0.008-0.021}$} & \multirow{2}{*}{$\frac{p \text {-value }}{0.00}$} \\
\hline Age (years) & $65-71$ vs. age $\leq 64$ & & & \\
\hline & $72-78$ vs. age $\leq 64$ & 0.032 & $0.026-0.039$ & 0.00 \\
\hline & $>78$ vs. age $\leq 64$ & 0.038 & $0.030-0.045$ & 0.00 \\
\hline \multicolumn{2}{|l|}{ Malle gender } & 0.014 & $0.009-0.019$ & 0.00 \\
\hline \multicolumn{2}{|l|}{ Hypertension } & -0.003 & $-0.008-0.002$ & 0.22 \\
\hline \multicolumn{2}{|c|}{ Diabetes mellitus } & 0.003 & $-0.003-0.009$ & 0.37 \\
\hline \multicolumn{2}{|c|}{ Diuretics } & 0.006 & $0.000-0.011$ & 0.05 \\
\hline \multicolumn{2}{|c|}{ White matter lesions } & 0.013 & $0.007-0.019$ & 0.00 \\
\hline \multicolumn{2}{|c|}{ Symptomatic lacunar us. cardio-embolic stroke } & 0.001 & $-0.006-0.008$ & 0.76 \\
\hline \multicolumn{2}{|c|}{ Symptomatic lacunar vs, atherothrombotic stroke } & 0.004 & $-0.001-0.009$ & 0.15 \\
\hline \multicolumn{2}{|c|}{ Silent small deep infarcts } & 0.006 & $0.000-0.012$ & 0.05 \\
\hline \multicolumn{2}{|c|}{ Silient territorial infarcts } & 0.018 & $0.008-0.027$ & 0.00 \\
\hline \multicolumn{2}{|c|}{ Rankin $=4$ or 5} & 0.004 & $-0.001-0.009$ & 0.14 \\
\hline
\end{tabular}

$\mathrm{B}=$ Regression coefficient. $\mathrm{Cl}=$ Confidence interwal.

finding deserves further study.

\section{Cerebral atrophy and multiple, usually silent infarcts}

In our stroke population ventricular enlargement was associated with silent small deep and silent territorial infarcts. Type of symptomatic stroke was of no influence, in agreement with the study of Hijdra et al. [86]. Previously, cerebral atrophy was found to be related to multi-infarct dementia $[71,98]$, and prior stroke $[122,147]$. We are not aware of a study on the relationship between silent infarcts and cerebral atrophy. Because both types of silent infarcts were related to ventricular enlargement, we do not think that a specific type (small-or large-vessel) of vasculopathy gives rise to ventricular enlargement. Merely, loss of cerebral tissue by multiple infarcts, leading to a. "hydrocephalus ex vacuo", seems a more probable hypothesis to explain this association.

\section{Cerebral atrophy and WMLs}

The association between cerebral atrophy and WMLs confirms the results of several other studies $[5,42,81,86,89,103,132,174,193]$. An increase in the $\mathrm{BCR}$ is a measure of ventricular enlargement which can point at either cerebral atrophy, or (normal pressure) lydrocephalus. Some authors $[56,155]$ suggest that CSF leakage into the adjacent periventricular brain parenclyma, and not a breakdown of myelin sheaths, may cause periventricular WMLs. This mechanism might play a role in the development of periventricular 


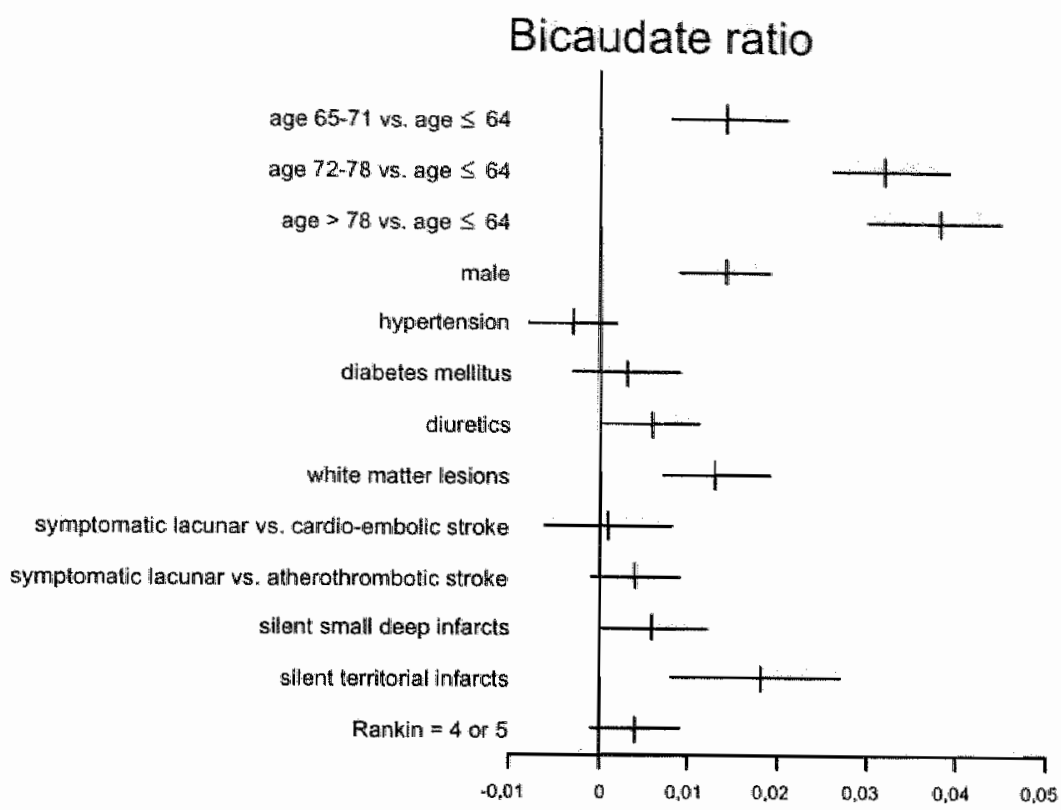

Figure 6.3: Linear regression coefficients with $95 \%$ confidence intervals of clinical and CT variables in relation to the bicaudate patio as dependent variable, in 917 stroke patients.

WMLs in (normal pressure) hydrocephalus, but can not explain deep WMIs. However, in our stroke patients this mechanism did probably not play a role in causing WMLs. Firstly, in our study both deep and periventricular WMLs were associated with ventricular enlargement, a finding that suggests similar causes for deep and periventricular WMILs in stroke patients. Secondly, similar vascular risk factor profiles in deep and periventricular WMLs do not argue in favour of a difference in pathogenesis between these two WMLtypes. Finally, none of our patients entered the study with the clinical syndrome of normal pressure hydrocephalus.

Mild periventricular hyperintensities on magmetic resonance imaging (MRI) scans are of no pathological significance and not associated with (normal pressure) hydrocephalus or vascular risk factors $[49,111,120,161,197]$. These periventricular hyperintensities seen on MRI are hardly visible on CT. The association between small deep infarcts and periventricular WMLs on CT suggests that these WMLs have a vascular cause.

Probably, also the association between ventricular enlargenent and WMLs is based on loss of white matter. This hypothesis is supported by a magnetic resonance spectroscopy study in patients with subcortical ischaemic vascular dementia [121], which showed a significant association between cerebral atrophy and a lower ratio of $N$-acetylaspartate and 
Table 6.3: Baseline characteristics and CT findings in the 3 subgroups of stroke patients in the WNIL-study.

\begin{tabular}{|c|c|c|c|c|c|}
\hline \multicolumn{2}{|c|}{ Baseline characteristics } & \multirow{3}{*}{$\begin{array}{l}\text { Total } \\
N=954\end{array}$} & \multicolumn{3}{|c|}{ Symptomatic stroke subgroups } \\
\hline & & & \multirow{2}{*}{$\begin{array}{c}\text { Lacunar } \\
N=330(35)\end{array}$} & \multirow{2}{*}{$\begin{array}{l}\text { Cardio-embolic } \\
N=210(22)\end{array}$} & \multirow{2}{*}{$\begin{array}{l}\text { Atherothrombotic/ } \\
\text { Undetermined cause } \\
\qquad N=414 \text { (43) }\end{array}$} \\
\hline & & & & & \\
\hline \multirow[t]{4}{*}{ Age (years) } & $\leq 64$ & $239(25)$ & $98(30)$ & $26(12)$ & $115(28)$ \\
\hline & $65-71$ & $234(25)$ & $89(27)$ & $46(22)$ & $99(24)$ \\
\hline & $72-78$ & $250(26)$ & $88(27)$ & $54(26)$ & $108(26)$ \\
\hline & $>78$ & $231(24)$ & $55(17)$ & $84(40)$ & $92(22)$ \\
\hline \multicolumn{2}{|l|}{ Male gender } & $495(52)$ & $185(56)$ & $89(42)$ & $221(53)$ \\
\hline \multicolumn{2}{|c|}{ Hypertension } & $435(46)$ & $158(48)$ & $102(49)$ & $175(42)$ \\
\hline \multicolumn{2}{|c|}{ Diabetes mellitus } & $191(20)$ & $65(20)$ & $46(22)$ & $80(19)$ \\
\hline \multicolumn{2}{|c|}{ Ischaemic heart disease } & $249(26)$ & $66(20)$ & $71(34)$ & $112(27)$ \\
\hline \multicolumn{2}{|c|}{ COPD } & $96(10)$ & $39(12)$ & $22(10)$ & $35(8)$ \\
\hline \multicolumn{2}{|l|}{ Diuretics } & $277(29)$ & $83(25)$ & $88(42)$ & $106(26)$ \\
\hline \multirow[t]{3}{*}{ Haematocrit: } & low & $149(16)$ & $37(11)$ & $45(21)$ & $67(16)$ \\
\hline & normal & $718(75)$ & $258(78)$ & $130(62)$ & $330(80)$ \\
\hline & high & $87(9)$ & $35(11)$ & $35(17)$ & $17(4)$ \\
\hline \multicolumn{2}{|c|}{ Rankin $=4$ or 5} & $491(51)$ & $103(31)$ & $143(68)$ & $245(59)$ \\
\hline \multirow[t]{3}{*}{ WMLs: } & total & $234(25)$ & $95(29)$ & $46(22)$ & $93(22)$ \\
\hline & deep & $117(12)$ & $46(14)$ & $20(10)$ & $51(12)$ \\
\hline & periventricular & $117(12)$ & $49(15)$ & $26(12)$ & $42(10)$ \\
\hline \multicolumn{2}{|c|}{ Silent small deep infarcts } & $221(23)$ & $101(31)$ & $35(17)$ & $85(21)$ \\
\hline \multicolumn{2}{|c|}{ Sillent territorial infarcts } & $61(6)$ & $14(4)$ & $18(9)$ & $29(7)$ \\
\hline
\end{tabular}

COPD $=$ Chronic obstructive pulmonary disease. $W M L=$ White matter lesion.

Percentages between parentheses.

creatinemcontaining metabolites in frontal white matter. This low ratio of metabolites is probably due to loss of, of injury to axons. Furthermore, Yamaguchi et al. [191] found decreased cerebral blood flow to be correlated with severe cerebral atrophy. They hypothesize the reduction of cerebral blood flow to be an adaptation to diminished metabolic demand, corresponding to loss of brain substance.

\section{Cerebral atrophy and cognitive impairment}

Several studies showed an association between cerebral atrophy and cognitive impairment $[29,42,71,115,116,150,176]$. Furthermore, Loeb et at.. $[115]$ found that patients with multi-infarct dementia had a slightly greater loss of cerebral substance, due to ischaemic lesions, than nondemented subjects with multiple infarcts. So, patients with a 


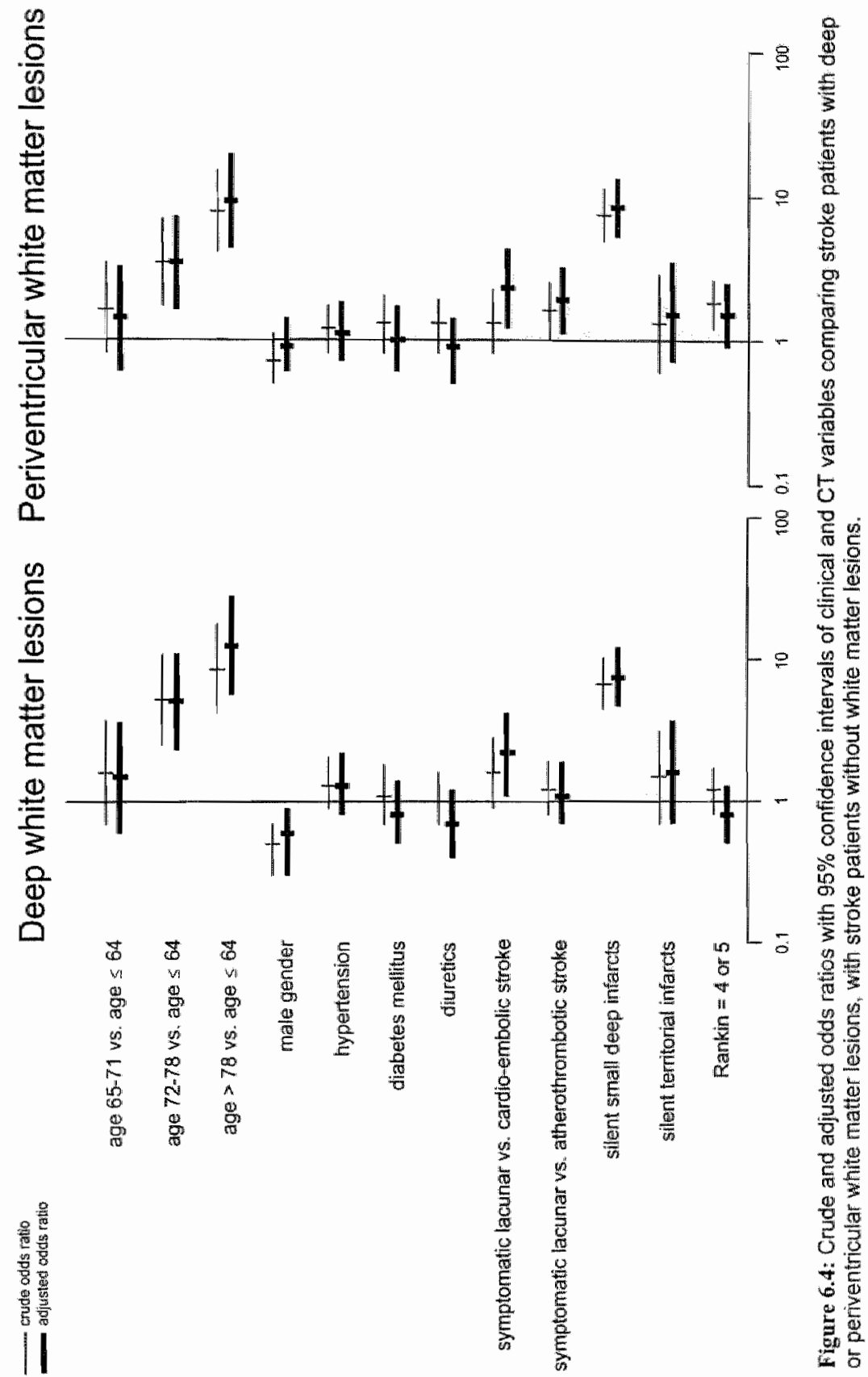


larger loss of cerebral tissue conld be more at risk of developing dementia.

We may conclude, firstly, that ventricular enlargement in ischaemic stroke patients is merely due to cerebral tissue loss, and not specifically associated to either small-or large-vessel disease; secondly, the findings that deep and periventricular WMLs had similar risk factor profles and were both related to ventricular enlargement, point at a similar, presumably vascular, pathogenesis. Cerebral atrophy in stroke patients seems to be due to different types of sustained injury to the brain, such as multiple small deep and territorial infarcts, or more diffuse injury due to WMLs. The type of underlying wascular pathology such as deep small-vessel disease, large-vessel thrombo-ernbolism, cardiogenic embolism, or arteriolosclerosis in the large-vessel territories in case of WMLs, had no specific effect on the degree of cerebral atrophy measured on CT shortly after stroke. Whether future cerebral tissue loss in stroke patients does not difler between stroke subtypes, remains to be studied. Treatment of vascular risk factors is not only important to reduce the incidence of recurrent stroke, it may also prevent further cerebral tissue loss and consequent cognitive decline. 


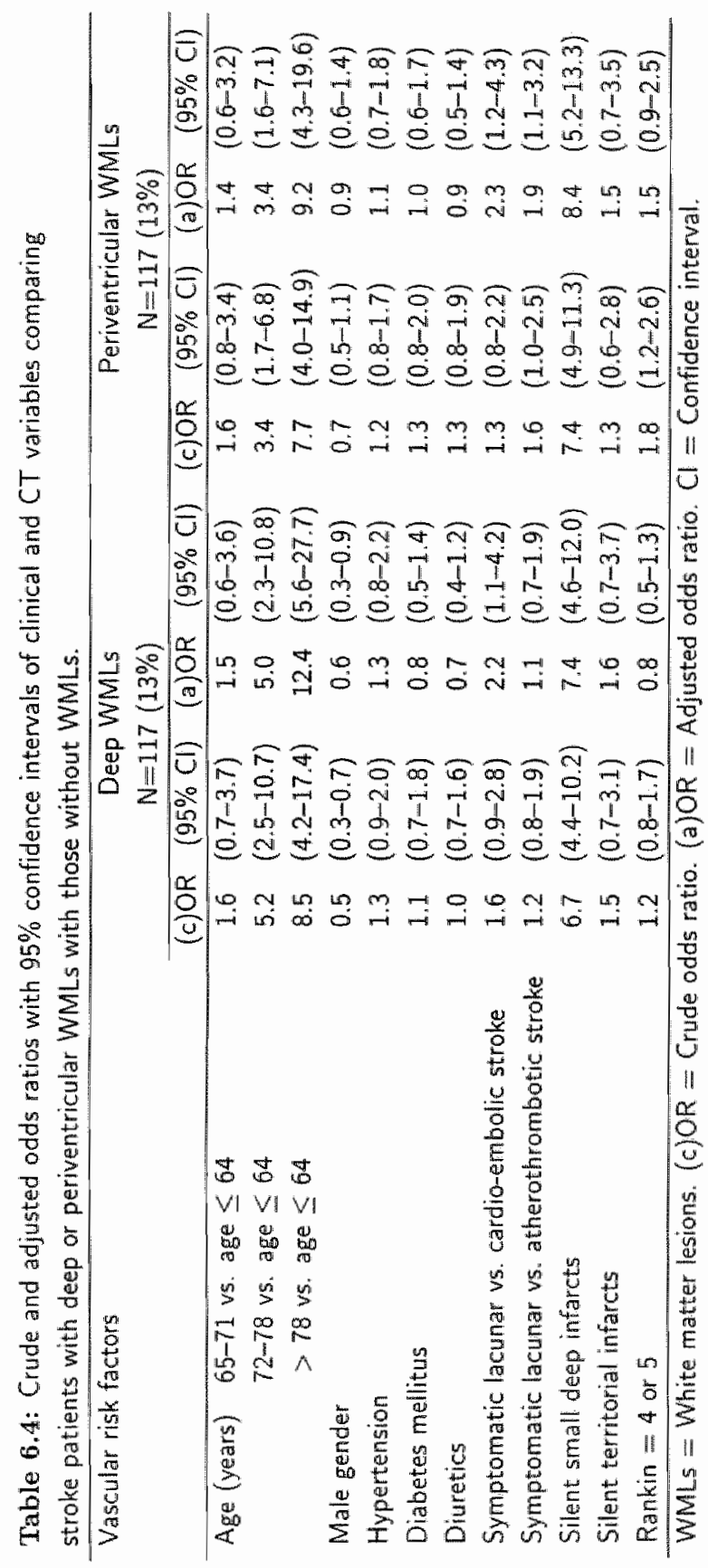




\section{7}

Gait disorder and parkinsonian signs in patients with stroke relate to small deep infarcts and white matter lesions

Adapted from:

Van Zagten M, Lodder J, Kessels F. Gait disorder and parkinsonian signs in patients with stroke relate to small deep infarcts and white matter lesions. Mow Disord In press. 


\section{Abstract}

Objectives: To study the prevalence of parkinsonian features (bradykinesia, rigidity, tremor, and gait disorder) in ischaemic stroke patients and their relationship with small deep or territorial infarcts, and white matter lesions (WMLs).

Design: Computed tomographic (CT) and clinical follow-up study in a cohort of 103 ischaemic stroke patients (median follow-up 3.0 years).

Setting: Primary and referral care centre.

Patients: Sixty-two of 144 registered patients with a first-ever symptomatic lacunar stroke and 41 of 155 with a territorial stroke not due to cardiac embolism, entered this study. Forty-seven (33\%) of the non-participating patients with a lacunar stroke and 54 $(35 \%)$ of those with a territorial stroke had died, $34(24 \%)$ and $57(37 \%)$, respectively, refused CT follow-up, and of 1 and 3 patients, respectively, the results of the neurologic examination were insufficient.

Main outcome measures: Parkinsonian features (bradykinesia, tremor, rigidity, and gait disorder) at follow-up, and the extent of WMLs, and the number of small deep and territorial infarets on CT scans at study entry and at follow-up.

Results: One or more parkinsonian signs were found in $36 \%$ of the patients; $11 \%$ clinically had parkinsonism. Parkinsonian signs were more frequent in lacunar than in territorial stroke patients: bradykinesia in $45 \%$ and $7 \%$, rigidity in $13 \%$ and $7 \%$, tremor in $6 \%$ and $7 \%$, gait disorder in $16 \%$ and $7 \%$, respectively. Patients with WMLs at study entry (N=16) were compared with those without $(\mathrm{N}=87)$ : $56 \%$ and $25 \%$ had bradykinesia, $25 \%$ and $8 \%$ rigidity, $25 \%$ and $3 \%$ tremor, $38 \%$ and $8 \%$ gait disorder, respectively. Multivariate regression analysis showed that WMLs at study entry were associated. with bradykinesia, gait disorder, and tremor. Bradykinesia was associated with lacunar stroke at study entry.

Conclusions: One third of our stroke patients had one or more parkinsonian signs. Ten percent clinically had a parkinsonian syndrome, that differed from Lewy-body parkinsonism: infrequent resting tremor, but frequent gait disorder. Parkinsonian signs were associated with WMLs, and lacunar stroke. Therefore, this study favours a distinct vascular parkinsonian syndrome. 


\section{Introduction}

The concept of vascular parkinsonism is still a matter of debate. Following the original description as a distinct syndrome by Critchley [40] it met much resistance until the introduction of computed tomography (CT) and later magnetic resonance imaging (MRI). These neuroimaging studies [149, 196] found vascular lesions, mainly small deep infarcts or white matter lesions (WMLs), to be related to certain parkinsonian features, which were considered to indicate a vascular cause of the syndrome. These features included: lower body parkinsonism [61], lack of resting tremor [88], marked gait difficulty $[8,126,168]$, and L-dopa unresponsiveness [6]]. However, most studies were done in selected parkinsonian patients who were compared with different types of controls, sometimes in rather small series. Patients at high risk of future progression of small deep infarcts or WMLs are those who suffered a symptomatic brain infarct [188]. If the proposed clinical signs of vascular parkinsonism would be related to (an increase of) especially small deep infarcts, WMLs, or both this would strengthen the concept of vascular parkinsonism. Therefore, we studied the prevalence of parkinsonian features, including gait disorder, in stroke patients selected for repeated CT at least 1 year after stroke. We related parkinsonian features to small deep infarcts and WMLs on CT.

\section{Patients and methods}

Patients were registered at the University Hospital of Maastricht between July 1987 and June 1992 in a prospective registry of all patients, admitted or visiting the out-patient clinic, with a firstmever supratentorial brain infarct with symptoms lasting longer than 24 hours. Rowtine investigations included standard blood tests, electrocardiogram, chest. $X$-ray, CT scan of the brain, and noninvasive carotid studies. Echocardiography, 24-hour ECG monitoring, and cerebral anglography were done in selected cases .

\section{Definitions}

The following vascular risk factors were recorded: age, gender, hypertension (known hypertension, or at least 2 separate blood pressure recordings of higher than $160 / 90 \mathrm{mmHg}$ before or at least 1 week after stroke), diabetes mellitus (known diabetes mellitus, or fasting serumglucose higher than $7 \mathrm{mmol} / 1$, or a postprandial serumglucose higher than $11 \mathrm{mmol} / \mathrm{l}$, both on at least 2 separate occasions), hypercholesterolemia (known hypercholesterolemia, or serumcholesterol higher than $6.4 \mathrm{mmol} / \mathrm{l}$ ), history of ischamic heart disease (myocardial infarction, angina pectoris), and cardiac source of embolism (atrial fibrillation, mitall stenosis, prosthetic aortic or mitral valve, recent myocardial infarction (within 6 weeks preceding stroke), endocarditis, cardiomyopathy, left ventricular anenrysm, intraventricular thrombus). 
Lacunar stroke was defined (1) as an acute stroke syndrome with $\mathrm{CT}$ findings compatible with occlusion of a single perforating artery, i.e., a small, subcortical, sharply marginated hypodense lesion with a diameter smaller than $20 \mathrm{~mm}$ (small deep infarct), or (2) as a speeific lacunar syndrome (i.e., unilateral motor and/or sensory symptoms and signs that completely involve at least 2 of 3 body parts (face, arm, and leg) without disturbance of consciousness or language, wisual field defect or other signs of cortical dysfunction) when the CT scan showed no specific lesion.

Tervitorial stroke was defined (1) as an acute stroke syndrome with CT findings compatible with infarction involving the cortex, or (2) when no specific lesion was visible on $\mathrm{CT}$, as a clinically identified cortical syndrome consisting of unilateral motor and $f$ or sensory symptoms and signs in combination with signs of cortical dysfunction with or without visual field defect, or as incomplete involvement of 2 body parts, or as isolated monoparesis [16], or as isolated cortical dysfunction (usually dysphasia). Patients with a large subcortical infarct were included in the territorial stroke group because of similar pathogenesis $[18,21]$. For the aim of this study we included patients with lacunar stroke, presumably due to small-vessel occlusion, and patients with territorial stroke presumably due to large-vessel atherosclerosis. Patients with a cardiac source of embolism or a specific stroke cause such as vasculitis, arterial dissection etc., were therefore not included in this study.

Silent brain infarct was defined as a low-density area on CT compatible with infarction but without a history of stroke, as taken from the patient's history, from family, or any other accessible information. Also, the stroke symptoms at study entry had to be anatomically incompatible with this infarct. Old infarcts can usually be distinguished from new ones becanse they are more hypodense, and there may be signs of surrounding tissue loss, like retraction of brain structures towards the infarct. Silent infarcts were also categorized as small deep or territorial.

Progression of small deep or territorial infarcts was defined as new symptomatic or silent infarcts visible on CT at follow-up, which were not visible on CT at study entry.

White malter lesions were defined as focal of diffuse hypodensities in the periventricular or deep white matter, not involving the cortex, and with ill-defined margins to distinguish them from infarction [168]. The presence of WMLs around frontal or occipital horns or in the centrum semiovale was noted separately. No effort was made to quantify the degree of white matter density in these different sites, as this might depend on the tuning of the CT scan. Patients were said to have WML progression when the CT' at study entry showed no WMLs, whereas the CT at follow-up did show WMLs, or when patients who had WMLs at study entry had new WMLs in other areas on the CT at follow-ap.

Bradykinesia was defined as slowness of initiation of voluntary movement with progressive reduction in speed and amplitude of repetitive actions [68]. 
Tremor was defined as any thythmical oscillatory movement, not elicited by action or position [144].

Ragdity was defined as an increased, waxlike or viscous resistance of a limb during the whole range of a passive movement [137]. Rigidity was differentiated from hypertonia, which in contrast with rigidity is a velocity-dependent resistance to passive movement, and paratonia, which is an uneven resistance to passive movement [144]. If doubt existed between hypertonia and rigidity, which was sometimes the case on the stroke-affected side, the findings on the not-affected side were taken as decisive.

Gait disorder was defined as a gait disturbance characterized by variable base, shuffing; short steps, start and turn hesitation, and moderate disequilibrium [145], not caused by paresis.

\section{Patient population}

Of 144 consecutively registered patients with a symptomatic lacunar and 155 with a symptomatic territorial stroke, 63 and 44 , respectively, entered this follow-up study. Four patients were excluded from the analysis, because the results of neurologic examination wete insufficient, leaving 103 patients (62 lacunar and 41 territorial stroke). Of the 81 registered lacunar and 111 territorial stroke patients who did not participate in this follow-up study, 47 lacunar and 54 territorial stroke patients had died, and 34 and 57 , respectively, refused follow-up CT mainly because they were unable to visit the out-patient clinic due to severe disablement. At follow-up we examined patients neurologically focusing on the following signs: bradykinesia, tremor, rigidity, and gait disorder. Presence or absence of these signs was judged clinically, by routine neurological physical exam at our ont-patient clinic. Medication used at follow-up was recorded. Median follow-up was 3.0 (range: 1.2 4.7) years: 2.8 (range: 1.24 .3 ) years in the lacunar and 3.2 (range: $1.7-4.7$ ) years in the verritorial stroke patients. All patients had CT at study entry and at follow-up. The median time between CT at study entry and at follow-up was 2.9 (range: 1.1-4.7) years: 2.8 (range: 1.2-4.3) years in the lacumar and 2.9 (range: 1.1-4.7) years in the territorial stroke patients. The CT scans made at study entry and at follow-up were mixed together and then reviewed for the presence and extensiveness of WNLs and for the number of small deep and territorial infarcts by 2 neurologists who were blind to the pationts' identity and the timing of the CT. Only those WMLs and infarcts on which both investigators agreed were registered. A third investigator analyzed whether the extensiveness of WMLs and/or the number of infarcts had changed during follow-up.

\section{Statistical analysis}

We described the relationship between the presence of each recorded sign (bradykinesiat, tremor, rigidity, gaitapraxia) and the clinical variables and $\mathrm{CT}$ features by means of bivariate statistical analysis with crude odds ratios $(C)$ OR) and $95 \%$ confidence intervals 
(CI) and by means of multivariate logistic regression analysis with adjusted odds ratios (a)OR). Because presence of 2 of the 3 investigated parkinsonian signs (bradykinesia, rigidity, tremor) is considlered obligatory for the diagnosis of parkinsonism [144], the presence of 2 of these signs was analyzed separately. Besides the vascular risk factors, the following clinical variables were included in various regression models: stroke subtype, Rankin (handicap) score at 3 months after stroke and at follow-up, duration of follow-up, presence of WMLs at study entry, presence of silent small deep or territorial infarcts at study entry, progression of WMLs, and progression of silent small deep or territorial infarctis. The Rankin scores were divided into 2 groups: functionally independent (Rankin $\leq 3$ ) or dependent (Rankin $=4$ or 5) Patients were categorized in 2 age-groups: 67 years or younger, and older than 67 years. We divided duration of follow-up in 3 categories: less than 1200 days, 1200 to 1400 days, and more than 1400 days. For all dependent variables, the older patients and the 2 "longer-duration of follow-up" categories were compared with the youngest patients and shortest follow-up category, respectively.

\section{Results}

In total, 37 patients (36\%) had one or more of the registered signs, and $11 \%$ had at least 2 parkinsonian signs (bradykinesia, rigidity, tremor), justifying the "diagnosis" parkinsonism. Clinical and CT features of the lacunar and territorial stroke patients are listed in Table 7.1, and Table 7.2 shows the clinical and CT features in patients with parkinsonian signs. Bradykinesia was found in $45 \%$ of lacunar stroke patients, and in only $7 \%$ of territorial stroke patients. Rigidity was slightly more frequent in lacunar stroke patients: $13 \% \mathrm{vs}$. $7 \%$ in territorial stroke patients. Tremor was evenly distributed in the 2 stroke subgroups (6\% in lacunar, and $7 \%$ in territorial stroke patients). In all cases it was a minor resting tremor, without specific parkinsonian aspects, such as "pill rolling". In $16 \%$ of lacunar stroke patients, and only $2 \%$ of territorial stroke patients, we found 2 of 3 parkinsonian signs, justifying the "diagnosis" of parkinsonism. Gait disorder was present in $16 \%$ of lacunar, and $7 \%$ of territorial stroke patients. In 1 patient gait was not assessable because of amputation of one leg. Median age was 58 (range: 30-85) years: 58 (range: 30-85) years in lacunar, and 60 (vange: $37-82$ ) years in territorial stroke patients. The number of patients in the different age-groups did not differ significantly between the 2 patient groups. There was an unbalanced distribution of follow-up duration between lacunar and territorial stroke patients in the category follow-up shorter than 1200 days ( $44 \% \mathrm{vs} .61 \%$, $\chi^{2}$-test: $\left.p=0.08\right)$, and in the category 1200 to 1400 days $\left(32 \%\right.$ ws. $12 \%, \chi^{2}$-test: $\left.p=0.02\right)$, respectively. None of the patients used antiparkinsonisn medication or medication known to cause parkinsonian signs.

In Table 7.1 also clinical and CT features are listed in patients with and without WMLs at study entry. WMLs occurred in $16 \%$ of all patients. WMLs were much more frequent in 
Table 7.1: Clinical and CT characteristics of patients with lacunar or territorial stroke, and of patients with and without white matter lesions at study entry.

\begin{tabular}{|c|c|c|c|c|c|}
\hline \multirow{3}{*}{$\begin{array}{l}\text { Clinical and CT } \\
\text { characteristics }\end{array}$} & \multicolumn{2}{|c|}{ Symptomatic stroke subgroups } & \multicolumn{2}{|c|}{ WMLs at study entry } & \multirow{3}{*}{$\begin{array}{c}\text { Total } \\
N=103\end{array}$} \\
\hline & Lacunar & Territorial & Present & Absent & \\
\hline & $N=62(60)$ & $N=41(40)$ & $N=16(16)$ & $N=87(84)$ & \\
\hline Elderly patients (> 67 yrs) & $20(32)$ & $12(29)$ & $7(44)$ & $25(29)$ & $32(31)$ \\
\hline Male gender & $42(68)$ & $25(61)$ & $11(69)$ & $56(64)$ & $67(65)$ \\
\hline Hypertension & $28(45)$ & $15(37)$ & $10(63)$ & $33(38)$ & $43(42)$ \\
\hline Diabetes mellitus & $11(18)$ & $6(15)$ & $2(13)$ & $15(17)$ & $17(17)$ \\
\hline Ischaemic heart disease & $7(11)$ & $13(3.2)$ & $5(31)$ & $15(27)$ & $20(19)$ \\
\hline Bradykinesia & $28(45)$ & $3(7)$ & $9(56)$ & $22(25)$ & $31(30)$ \\
\hline Rigidity & $8(13)$ & $3(7)$ & $4(25)$ & $7(8)$ & $11(11)$ \\
\hline Tremor & $4(6)$ & $3(7)$ & $4(25)$ & $3(3)$ & $7(7)$ \\
\hline 2 of 3 Parkinsonian signs* & $10(16)$ & $1(2)$ & $6(38)$ & $5(6)$ & $11(11)$ \\
\hline Gait disorder & $10(16)$ & $3(7)$ & $6(38)$ & $7(8)$ & $13(13)$ \\
\hline Silent SDIs at study entry & $10(16)$ & $7(17)$ & $7(44)$ & $10(11)$ & $17(17)$ \\
\hline Sillent Tls at study entry & $1(2)$ & 0 & 0 & $1(1)$ & $1(1)$ \\
\hline WML progression & $22(35)$ & $4(10)$ & $6(38)$ & $20(23)$ & $26(27)$ \\
\hline SDI progression & $36(58)$ & $4(10)$ & $9(56)$ & $31(36)$ & $40(39)$ \\
\hline Tll progression & $3(5)$ & $11(27)$ & $4(25)$ & $10(11)$ & $14(1.4)$ \\
\hline \multicolumn{6}{|l|}{ Follow-up duration } \\
\hline$<1200$ days & $27(44)$ & $25(61)$ & $9(56)$ & $43(49)$ & $52(50)$ \\
\hline $1200-1400$ days & $20(32)$ & $5(12)$ & $4(25)$ & $21(24)$ & $25(24)$ \\
\hline$>1400$ days & $15(24)$ & $11(27)$ & $3(19)$ & $23(26)$ & $26(25)$ \\
\hline
\end{tabular}

WMLs $=$ White matter lesions. SDI $=$ Small deep infarct. $\mathrm{TI}=$ Territorial infarct.

* Parkinsonian signs: bradykinesia, rigidity, tremor. Percentages between parentheses.

patients with bradykinesia (56\%), rigidity (25\%), tremor (25\%), gait disomer (38\%), and with presence of 2 or 3 parkinsonian signs (38\%). Hypertension, ischaemic heart disease, and silent small deep infarcts at study entry were more frequently found in patients with WMLs, compared with those without. We did not find lesions involving the substantia nigra. However, C $\mathrm{C}$ is not very reliable in finding or excluding lesions in this area, because of frequent artefacts.

Table 7.9 and Figures 7.1 and. 7.2 show the results of the bivariate and multivariate 10 gistic regression analysis of the most relevant model of clinical variables, expressed as crude and adjusted odds ratios, respectively, with bradykinesia, tremor, rigidity, gait disorder, or with the combination of at least 2 parkinsonian signs as dependent variables. In the analysis of tremor WML progression was left out as clinical variable because no patient with tremor had WML progression. Bradykinesia was associated with higher age ((a)OR 4.1, 


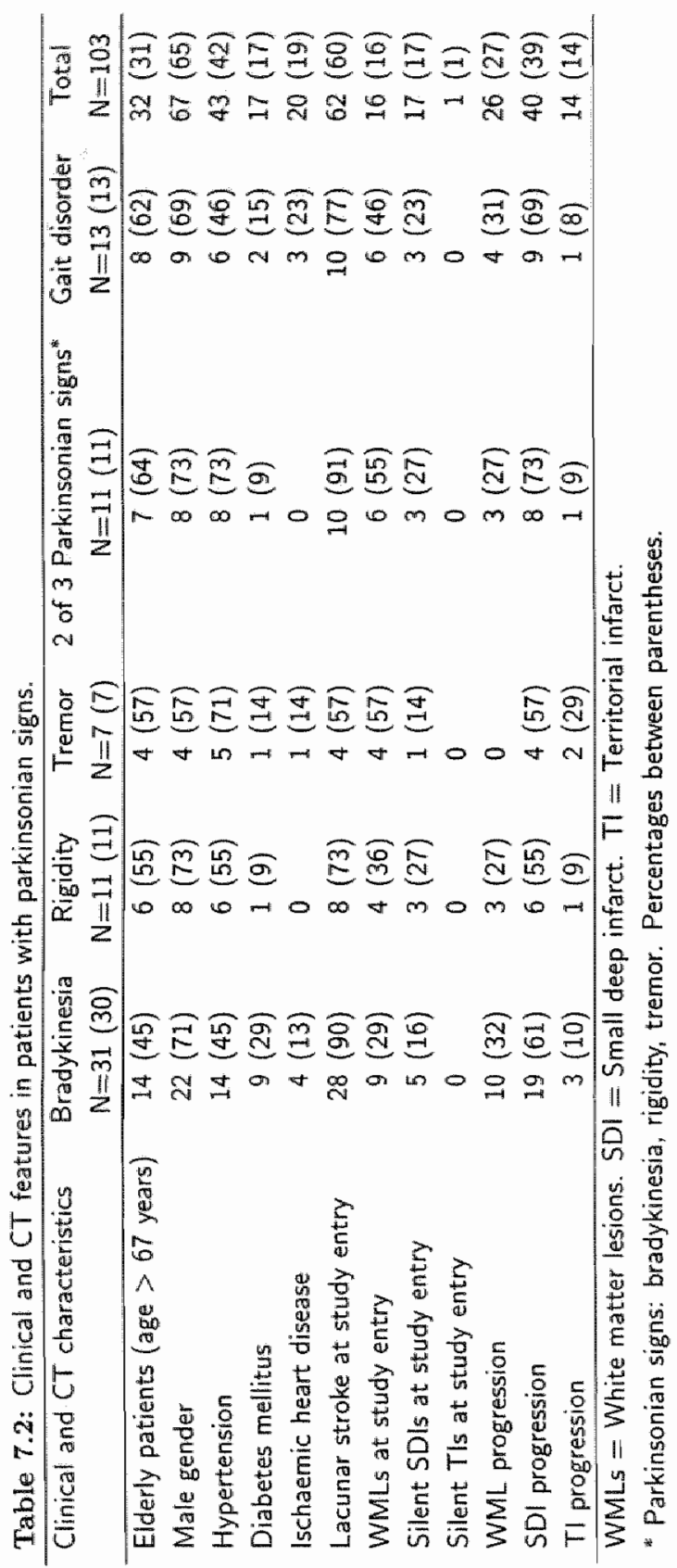



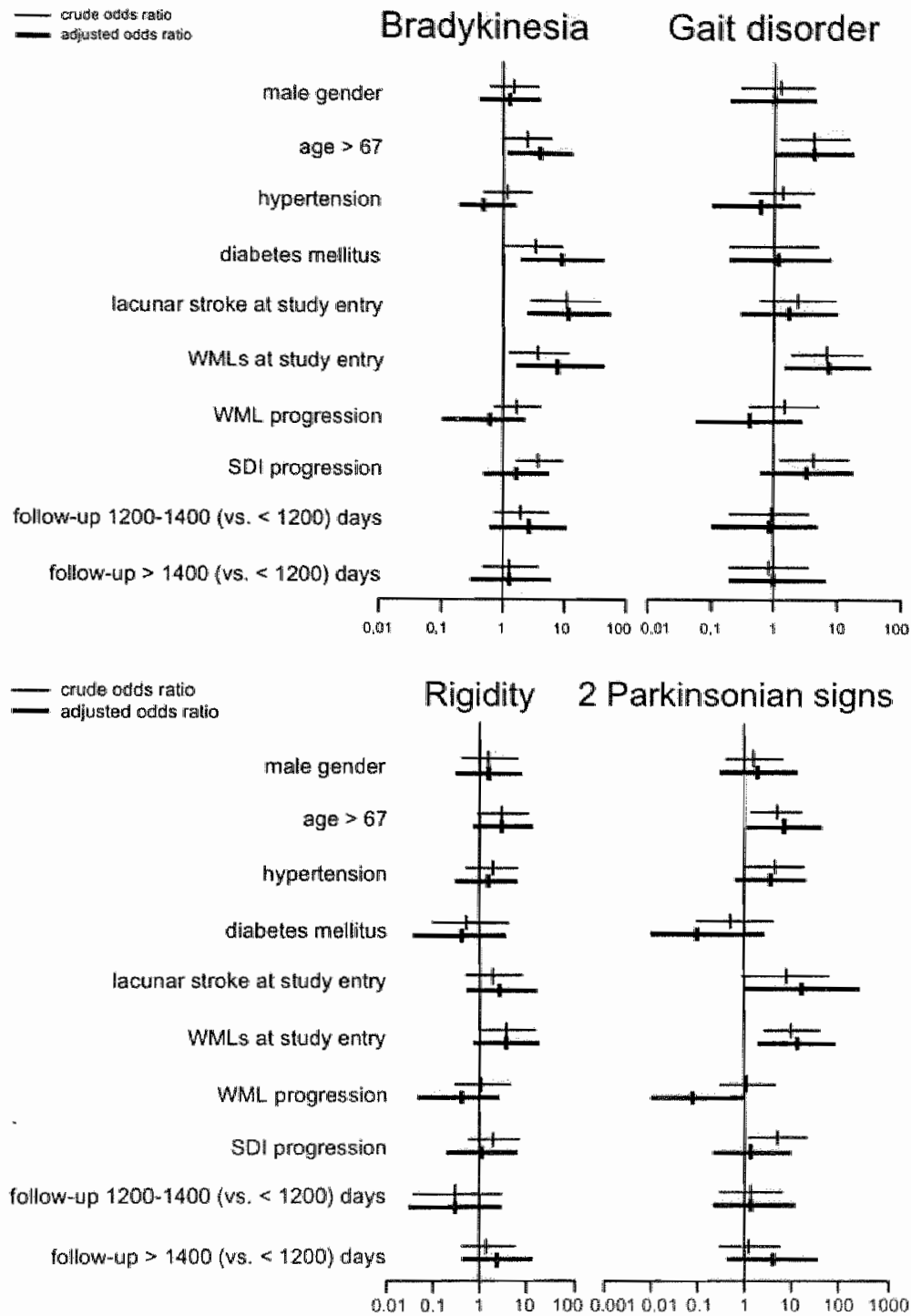

Figure 7.1: Crude and adjusted odds ratios with $95 \%$ confidence intervals of clinical variables in patients with bradykinesia, gait disorder, rigidity, and 2 of 3 parkinsonian signs. WMLs = White matter lesions. SDI = Small deep infarct. Parkinsonian signs: bradykinesia, rigidity, tremor. 


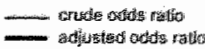

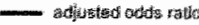

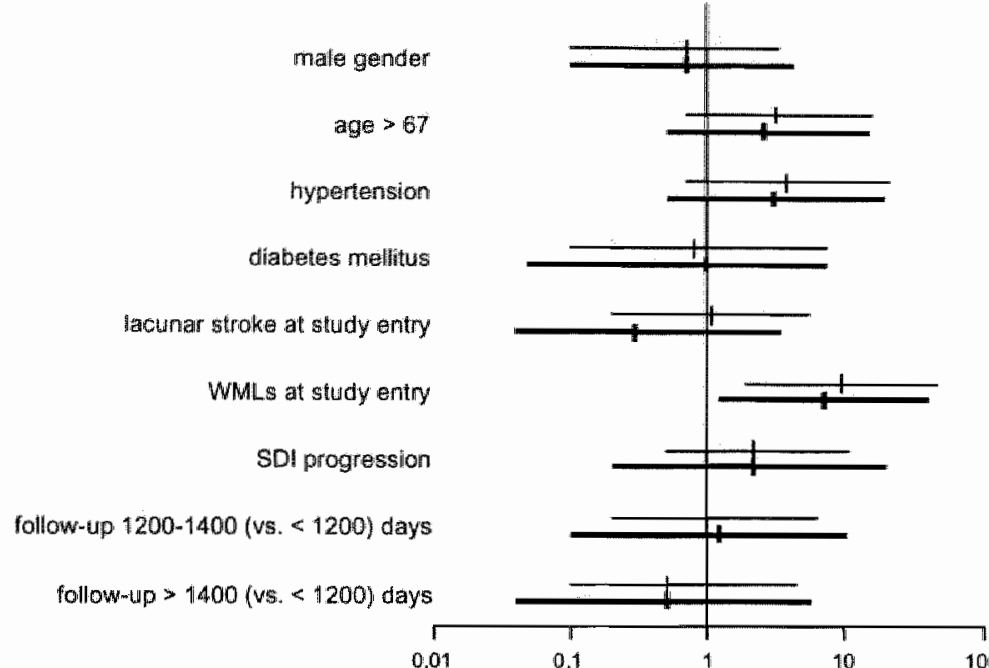

Figure 7.2: Crude and adjusted odds ratios with $95 \%$ confidence intervals of clinical variables in patients with tremor. WMLs $=$ White matter lesions. SDI = Small deep infarct.

$95 \%$ CI 1.2-13.9), diabetes mellitus ((a)OR 9.2, 95\% CI 1.9-43.7), lacunar stroke at study entry ((a)OR 11.5, 95\% CI 2.4-54.9), and with WMLs at study entry (a)OR 8.0, 95\% CI 1.6-41.6). Gait disorder was related to higher age ((a) OR 4.0, 95\% CI 1.0-16.8), and WMLs at study entry ((a)OR $7.1,95 \%$ CI $1.5-33.7)$. Tremor was associated with WMLs at study entry ((a)OR 7.0,95\% CI 1.2-40.3). No clinical variable was significantly related to rigidity. Two out of three parkinsonian signs (bradykinesia, tremor, rigidity) were associated with higher age ( a) OR 6.7, 95\% CI 1.1-42.4), lacunar stroke at study entry ((a)OR 16.4,95\% OI 1.0-271.9), and WMLs at study entry ((a)OR 12.6, 95\% CI 1.8-87.7). Eight of these patients also bad gait disorder. There was a negative association between the presence of at least 2 parkinsonian signs and WML progression (a)OR 0.08, 95\% CI $0.01-1.0)$.

\section{Discussion}

We found that more than one third of patients with a first cerebral infarct, after a median follow-up of 3 years, had parkinsonian signs, and in $10 \%$ of the patients there was a parkinsonian syndrome. Bradykinesia, gat disorder, and rigidity were more frequent among lacunar, than among tenitorial stroke patients. Patients with WMLs at study entry had 
more than twice as often parkinsonian signs than pattents without WMLs. Parkinsonian signs were associated with WMLs at study entry, lacunar stroke at study entry, and higher age.

Not all patients initially included in our stroke registry were avalable for follow-up, which may have created bias, but if so, most likely towards underdetection of parkinsonian signs: most patients not investigated had died, or were severely disabled, because of which the younger and relatively less disabled patients participated in the study. We judged the presence of parkinsonian signs clinically, without quantification, merely to measure the frequency of parkinsonian features to study the development of "vascular parkinsonism" in stroke patients. Unfortunately we had no information on the presence of parkinsonian. signs at stroke onset.

In 3 patients, the initial CT scans showed more extensive WMLs than the follow-up CT scans. In search for an explanation of this apparently odd finding, we reviewed the $2 \mathrm{CT}$ scans of each patient. In these 3 patients, the follow-up CT scans showed diminished black-and-white contrast compared with the initial CT scans, which may have led to an underestimation of the extensiveness of WMLs. Furthermore, 1 of the 3 patients had WMLs around the occipital horns on the initial CT scan. The follow-up CT scan in this patient showed a large infarct in the territory of the middle cerebral artery extending around the occipital horn, which interfered with judgement of WMLs in this area. There were no signs of ventricular enlargement or changes in ventricular size in follow up $C T$ scans compared with the initial CT scans in these 3 patients. Therefore, intra-observer variability, rather than real change, such as might occur in periventricular WMLs related to (normal pressure) hydrocephalus $[51,56,106,132]$, may explain these discrepancies.

The absence of resting tremor [88], so-called lower body parkinsonism (marked gait disorder with mimimal upper limb involvement), and L-dopa unresponsiveness are often considered to point at a wascular cause [61], but not always [88]. In our study only $19 \%$ of patients with one or more parkinsonian signs had a resting tremor, none of which had the typical "pill-rolling" aspect. Gait disorder was found in 35\% of patients with one or more parkinsonian sign.

Whether a non-Lewy-body-related, vascular parkinsonism exists can not casily be inferred from studying patients with Parkinson's disease. Although such patients may hawe vascular lesions, it remains difficult to identify the relevance of such lesions as a cause of the clinical signs. Studying parkinsonian signs in vascular compromised patientis would be more appropriate, but such studies have scarcely been perforned except for a lew case reports $[138,180]$. Reider-Groswasser et al. [152] found in 45 patients with small deep (lacumar) infarcts in the basal ganglia on $\mathrm{CT}$, in $38 \%$ parkinsonism, $31 \%$ hemiparesis, and in $20 \%$ both parkinsonism and hemiparesis. In our study, of all parkinsonian signs only bradykinesia and presence of 2 out of 3 parkinsonian signs were associated with lacunar stroke at study entry. No parkinsonian sign was associated with progression of small deep 
infarcts. Because of a strong relationship between WMLs and small deep infarcts [188] and the fact that both these features were entered in our regression model, any correlation between parkinsonian signs other than bradykinesia and presence of 2 out of 3 parkinsonian signs, and small deep infarcts may have been masked.

Several authors investigated neuroimaging findings in patients with a parkinsonian syndrome or gait disorder. Zijlmans et al. [196] found significantly more subcortical white or grey matter lesions on MRI scans in patients with suspected vascular parkinsonism than in patients with Parkinson's disease or those with hypertension. Piccini et al. [149] found significantly more often WMLs on MRI scans in patients with Parkinson's disease than in healthy subjects. In $33 \%$ of patients with progressive supranuclear palsy a multi-infarct state was found [44]. WMLs were also frequent in patients with gait and balance disorders $[8,126,168]$, in multi-infarct dementia patients with gait disorder [179], and in patients with Alzheimer disease and gait disorder [12]. These studies, including ours, point at a relationship between cerebral ischaemia and parkinsonian features including gait disorder, whereas the clinical syndrome differs from that of Lewy-body Parkinson's disease. This makes a syndrome of "vascular parkinsonism" very likely.

Why are WMLs and lacunar stroke associated with parkinsonian signs? Both small deep (lacunar) infarcts and WMLs, but not territorial infarcts, may damage the basal ganglia-thalamocortical circuit, resulting in parkinsonian signs. In patients with striatal infarcts Nakane et al. [139] showed degenerative change in the ipsilateral substantia nigra 2 weeks after stroke, as a possible result from excessive excitation due to loss of inhibitory $\gamma$-aminobutyric acid (GABA)ergic input. However, in another study [192] in vascularparkinsonism patients not a significant decrease in number of pigmented neurons in the substantia nigra, but less oligodendrocytes in the frontal white matter were found. Small cleep (lacunar) infarcts and WMLs are both thought to be caused by small-vessel disease [3, $7,28,31,162,187]$. The presence of both small deep infarets and WMLs may reflect a more advanced stage of small-vessel disease, with consequently more seriously affected patients.

We found WMLs at study entry but not WML progression associated with parkinsonian signs. It could be that the period during which WMLs progressed in our study was too short for the development of parkinsonian signs, whereas WMLs at study entry might have existed for a longer time. As we are not informed about how long WMLs at study entry existed, this remains speculative.

In conchusion: one third of our stroke patients had one or more parkinsonian signs, $10 \%$ had the clinical syndrome of parkinsonism. Clinically the parkinsonian syndrome in these stroke patients differed from that in Lewy-body parkinsonism: resting tremor was infrequent, whereas gait disorder was often found. As parkinsonian signs were associated with WMLs and lacunar stroke, small-vessel disease located in either the deep structures or the white matter may be the major cause of "vascular parkinsonism". 


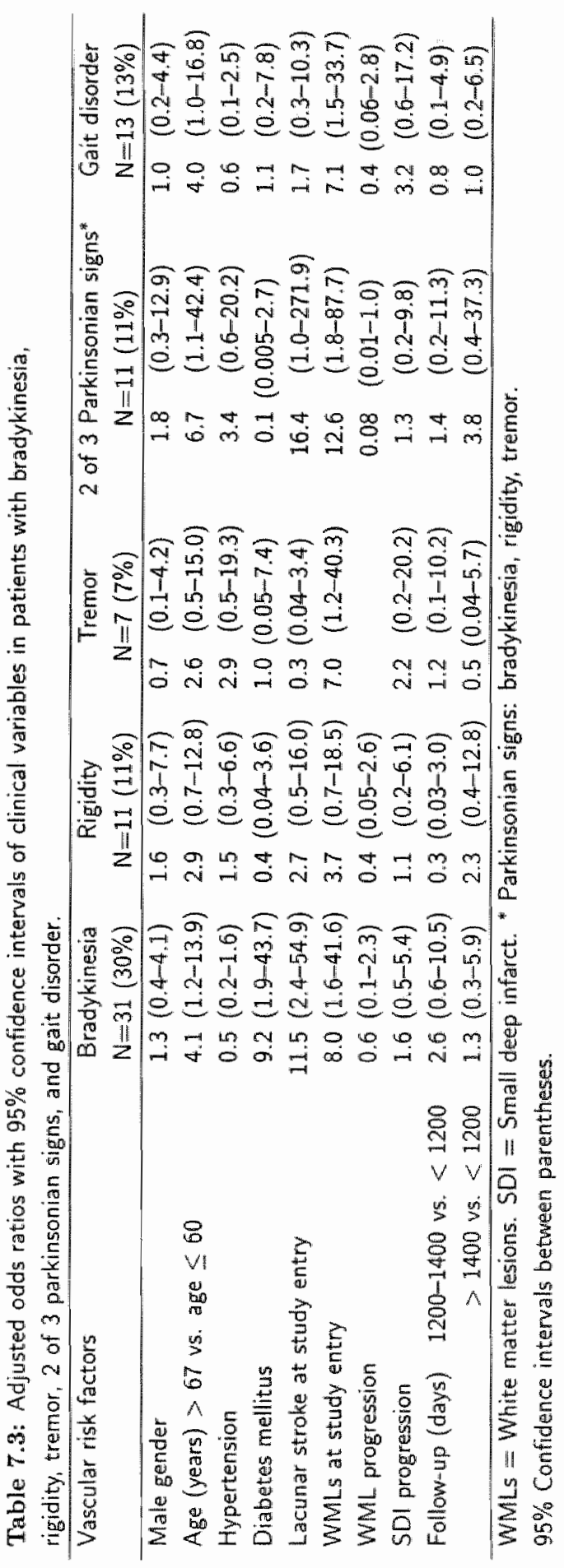


8

General discussion 
Now it is time to see whether we succeeded in trying to shed more light on cerebral smallvessel disease. Is cerebral small-vessel disease an entity or must it according to pathogenesis be further differentiated?

\section{Cerebral small-vessel disease, its pathogenesis and vascular risk factors}

Distinguishing types of cerebral small-vessel disease may be important in the planning of stroke treatment trials. Although additional pathologic studies would be of great value they are difficult to perform because of the low early case-fatality rate and consequently the low autopsy rate for lacunar stroke patients $[10,114]$. Therefore, we need to use other methods of examining whether two types of small-vesse]. disease can be distinguished. Comparing the vascular risk factor profilles, clinical manifestations and disease progression in patients with different types of lesions caused by small-vessel disease could add to our understanding of cerebral small-vessel disease. Furthermore, in this way tools may be gathered to recognize patients with different types of small-vessel disease by looking at their vascular risk factors and their symptoms and signs.

This study showed a clear relationship between WMLs and small deep (lacunar) infarcts. WMLs were especially associated with multiple, mostly silent small deep infarcts. WMLs are thought to result from arteriolosclerosis. Two distinct types of small-vessel disease seem to be involved in small deep (lacunar) infarcts. Single symptomatic small deep (lacunar) infarcts are thought to be caused by microatheromatosis, whereas the somewhat smaller, sillent ones are probably caused by arteriolosclerosis. The strong association we found between WMLs and multiple, usually silent small deep infarcts supports the idea of arteriolosclerosis causing WMLs and multiple, usually silent small deep infarcts.

In primary intracerebral haemorrhage, mostly located in the basal ganglia and thalamus, arteriolosclerosis is also the most prevalent vasculopathy, as shown in post-mortem studies. The risk factor profile of patients with primary intracerebral haemorrhage differed in our study from that in symptomatic lacmar stroke patients. Althougl indirectly, this finding also adds exidence to the idea of two distinct types of small-vessel disease: primary intracenebral haemomhage is probably caused by arteriolosiclerosis, and most symptomatic lacunar stroke by the other type of small-vessel disease, i.e., microatheromatosis. So, arteriolosclerosis may lead both to primary intracerebral haemorrhage, and to multiple, usually silent; small deep infarcts. In both hypertension is the most important risk factor. However, what other factors play a role in causing either an ischaemic lesion or a haemorrhage in pulients with this small-vessel disease is unknown. Duration and severity of hypertension, daily blood pressure fuctuations (e.g., a sudclen rise of blood pressure) and effects of treatment may be relevant in this respect. Constitutional factors may also be involved.

The relationship between WMLs and multiple, usually small deep infarcts is remarkable, becanse they occur in different vascular territories: multiple silent small deep infarcts in the territory of small deep penetrating arteries, and WMLs in the territory of the superficial 
perforating branches of large cerebral arteries. The vascullopathy that results in WMLs and multiple silent small deep infarets may therefore be pathologically homogeneous but heterogeneous as to the affected cerebral vascular system. What causes deep perforating vessels to react with infarction and the superficial system with "incomplete infarction" and demyelination remains unclear. Hypothetically, because of differences between basal ganglia and white matter in vascular anatomy and cerebral blood flow regulation, vascular insufficiency might lead to small infarcts in the basal ganglia, and to confluent areas of demyellination, axonal loss, dilated perivascular spaces, and gliosis in the white matter.

In our study, in accordance with several other studies, the association between WMLs and hypertension could not be confimed. Several reasons may be responsible for this finding. Firstly, hypertension may not be identified as a discriminator in the different subgroups of stroke population which already has a high frequency of hypertension and end-organ damage due to hypertension. Secondly, antihypertensive treatment in our stroke patients may have weakened the effect of hypertension as a risk factor. Furthermore, in the very old, the importance of elevated blood pressure for the risk of vascular disease seenus to diminish or even reverse. Since cardiovascular risk factors are all associated with increased mortality, very old survivors with these risk factors may form a selected group resistant to the damaging effects of hypertension. Age may be a far more important risk factor in the elderly than bypertension.

We found that both multiple, usually silent small deep infarcts and WMI Ls occur mostly in lacunar stroke patients. This suggests that the two distinct entities of small-vessel disease often occur simultaneonsly, for both multiple, usually silent small deep infarcts and WMLs are probably due to arteriolosclerosis, whereas symptomatic lacunar stroke is mostly caused by microatheromatiosis. The reasons for small deep infarcts caused by arteriolosclerosis to be usually silent, are probably that these infarcts are often smaller than symptomatic small deep (lacunar) infarcts, and located in "neurologically sillent" areas. Hypertension probably is the common risk factor in both these types of small-vessel disease, whereas more severe hypertension may result in arteriolosclerosis.

Although symptomatic lacunar stroke is thought to be caused by atheromatosis of the small vessels, lacunar stroke patients usually do not have evidence of atheromatosic of the large vessels (e.g., carotid stenosis). Why atheromatosis affects large (e.g., carotid) arteries in some patients and small arteries in others is not known. Maybe race is of intluence here: Caucasians more often hawe extracranial vasculopathy, whereas Asiatics more frequently suffer from intracranial vasculopathy. Here also, more effort should be devoted to study the sevarity of hypertension as an independent predictor of stroke subtype as some patients may need more diligent antihypertensive treatment. Regular treatment may not suffice as arteriolosclerosis may progress despite such treatment, as we showed. 


\section{Progression of cerebral small-vessel disease and its long-term sequelae}

We found, 3 years after the first-ever stroke, in $26 \%$ of ischaemic stroke patients progression of WMLs and in 38\% progression of small deep infarcts. Both occurred mainly in lacunar stroke patients. It is both amazing and disappointing that WMLs and small deep infarcts were rapidly progressive despite standard stroke treatment. Our stroke patients were treated according to present standards, i.e., treatment of vascular risk factors (e.g., with antismoking advise, antilinyertensives, antidiabetics, and diet) and treatment, with aspirin or anticoágulants. Possibly, antihypertensive treatment was not sufficient, or at the time the treatment was started end-organ damage had advanced too far. However, we do not have detailed information on blood pressure over time in our patients, such as the duration and severity of hypertension, daily blood pressure fluctuations and effects of treatment, partly because the treatment was usually done by the general practitioner, cardiologist or specialist for internal diseases. Currently a study is ongoing in our department regarding these aspects of hypertension and its effects on WMLs. However, it could be that hypertension is not really the causative factor in arteriolosclerosis. Hypothetically, both byjertension and arteriolosclerosis may result from another yet unknown (e.g., genetic or environmental) factor.

Apart from morbidity directly caused by the stroke, we showed that one third of ischaemic stroke survivors examined 3 years after stroke had additional morbidity due to parkinsonian signs. Ten percent actually had the clinical syndrome of parkinsonism. Clinically the parkinsonian syndrome in these stroke patients differed from that in Lewy-body parkinsonism: resting tremor was infrequent, whereas gait disorder was often found. These parkinsonian signs were associated with WMLs and lacunar stroke, and therefore probably result from cerebral small-vessel clisease. We think that WMLs and lacunar stroke cause multiple lesions in the basal ganglia-thalamocortical circuit, resulting in parkinsonian signs. Our study supports the idea of "vascular parkinsonism" as a distinct parkinsonian syndrome with specific symptoms and signs, and etiology. We found WMLs at study entry but not WML progression associated with parkinsonian signs. It could be that the period during which WMLs progressed in our study was too short for the development of parkinsonian signs, whereas WMLs at study entry might have existed for a longer time. As we are not informed about how long WMLs at study entry existed, this remains speculative. For this reason a prospective follow-up study of first-ever ischaemic stroke patients will soon start in our department, that aims at a more extensive investigation of the prevalence and canses of parkinsonian signs in stroke patients.

Cerebral ventricular enlargement in ischaemic stroke patients was not associated with a specific ischaemic stroke subtype. Probably, ventricular enlargement is merely due to cerebral tissue loss, irrespective of the causative factor. In view of the relation between cerebral atrophy and cognitive impairment, prevention of any type of stroke might be an important issue. Furthermore, we found that both deep and periventricular WMLs 
had similar risk factor profiles, and were both related to ventricular enlargement. Some authors suggest that periventricular WMLs in normal pressure hydrocephalus may result from leakage of cerebrospinal fluid into the adjacent periventricular brain parenchyma, and thus may not result from a vascular cause. Our results indicate that this mechanism is not. frequent in periventricular WMLs in stroke patients.

As stated in the general introduction, the aim of the studies described in this thesis was to investigate clinically whether heterogeneity of cerebral vascular lesions (intracerebral haemomhage, different types of small deep infarcts, and WNLs) coincided with homogeneity as to the underlying type of cerebral vascular disease. It may be concluded that this is largely the case; except for single, symptomatic lacunar infarcts (due to small-vessel atheromatosis) the remaining lesions are caused by arteriolosclerosis. Further stucly of factors determining the heterogeneity in cerebral lesions remains of utmost importance in aiming to arrive at a better treatment of cerebral small-vessel disease. Furthermore, regarding the progression of WMLs and small deep infarcts, and the morbidity due to vascular parkinsonism, the search for a specific therapeutical option in cerebral small-vessel disease is also an important issue. More knowledge on various aspects of hypertension in relationship with end-organ (brain) damage could lead to such options, as hypertension is probably the most important wisk factor in cerebral small-vessel disease. Such studies are currently being done. 


\section{Summary}

Stroke is a general term for several types of vascular injuries to the brain. Risk factor profiles, symptoms and signs, pathogenesis, therapy, prognosis, and long-term sequelae differ among stroke subtypes. To arrive at effective prevention of stroke, knowledge of what causes a stroke in individual patients is needed. The risk reduction of stroke achieved by carotid surgery and anticoagulation-therapy in certain stroke subgroups, shows that effective intervention depends on the pathogenesis and vascular risk factor profile.

In this study we chose to investigate several aspects of lesions presumably caused by cerebral small-vessel disease, such as small deep (lacunar) infarcts, white matter lesions (WMLs), and primary deep intracerebral haemorrhage. We aimed firstly to investigate whether these heterogeneous lesions are homogeneous as to the type of underlying vascular disease (presumably cerebral small-vessel disease). The type of cerebral small-vessel disease probably differs among these lesions. Post-mortem studies showed that arteriolosclerosis of the deep penetrating arteries and arterioles is the underlying vasculopathy in primary deep intracerebral haemorrhage. In small deep (lacunar) infarcts pathological evidence points at two distinct small-vessel diseases: arteriolosclerosis in multiple, usually silent small deep infarcts, and microatheromatosis in the somewhat larger symptomatic ones. Although in WMLs sometimes a mixture of pathologic changes is found, many authors hold arteriolosclerosis as the underlying vasculopathy. Furthermore, possible long-term consequences of cerebral small-vessel disease were investigated, such as cerebral atrophy and vascular parkinsonism.

In Chapter 2 the vascular risk factor profiles in patients with a primary deep intracerebral haemorrhage, a lacunar or territorial stroke were compared, assuming that such profles may be indicative of the nature of the underlying vasculopathy. A history of ischaemic heart disease and diabetes mellitus were more strongly associated with ischnemic stroke of either type than with primary intracerebral haemorrhage. Hypertension did not emerge as an independent variable associated with stroke subtype. These differences in vascular risk factors do not support the idea of a similar mature of the underlying small-vessel disease in primary intracerebral thaemorrhage and the majority of lacunar strokes.

In Chapter 3 the progression over time of WMLs and the number of small deep and territorial infarcts in stroke patients was studied. Furthermore, the hypothesis was tested that WMLs are associated with small deep infarcts. We performed a computed tomogra- 
phic (CT) follow-up study in a cohort of 107 ischaemic stroke patients (median follow-up 3.0 years). WMLs progressed in $26 \%$ of the patients. This progression was associated with symptomatic lacunar stroke at study entry, silent small deep infarcts at study entry, old age, and longer follow-up. We found progression of small deep infarcts in $38 \%$ of the patients. The progression was associated with symptomatic lacunar stroke at study entry and longer follow-up. Progression of both WMLs and small deep infarcts, which occurred in $16 \%$ of the patients, was related to symptomatic lacumar stroke at study entry, silent small deep infarcts at study entry, and longer follow-up. The number of territorial infarcts increased in $13 \%$ of the patients. This increase was associated with symptomatic territorial stroke at study entry and a history of ischaemic heart disease. We concluded that the marked progression of WMLs and small deep infarcts that occurred mainly in lacunar stroke patients suggests that both WMLs and small deep (lacunar) infarcts are caused by a small-vessel disease, which is progressive despite standard stroke treatment.

In Chapter 4 the hypothesis was tested that WMLs are especially associated with multiple, usually silent small deep infarcts. We studied the incidence of WMLs in 960 first-ever ischaemic stroke patients: 332 patients with a lacunar stroke, 213 with a cardio-embolic territorial stroke, and 41.5 with a atherothrombotic territorial stroke. Furthermore, we determined the relationship of WMLs with vascular risk factors, symptomatic and silent infarcts. Of all stroke patients $24 \%$ had WMLs. WMLs were associated with higher age, lacunar stroke and, very strongly, with silent small deep infarcts. Furthermore, WMLs were related to silent territorial infarcts in the atherothrombotic stroke subgroup. We concluded that these findings support the hypothesis that WMLs and multiple, usually silent small deep infarcts have the same vascular cause, namely arteriolosclerosis.

Aiming to test whether cerebral atrophy in stroke patients is related to presence of WMLs and stroke we first assessed and compared the interobserver variability of two cerebralatrophy measures on CT scans in Chapter 5. The bicaudate ratio (BCR) and the Sylvian fissure ratio (SFR) were measured on $20 \mathrm{CT}$ scans of ischaemic stroke patients by 3 investigators. The intraclass correlation coefficient of BCR measurements was 0.82 (95\% confidence interval (CI) $0.75-0.94$ ), and of SFR measurements 0.69 (95\% CI 0.57-0.89). The range of Pearson correlation coefficients calculated for all pairs of investigators was smaller in the measurements of the BCR (0.89 to 0.92), than in the SFR measurements $(0.66$ to 0.84). So, the interobserver agreement of the BCR measurements was excellent and that of the SFR measurements only moderate.

In Chapter 6 the results are shown of the cerebral atrophy study. Cerebral atrophy was measured by the BCR, in 917 first-ever ischaemic stroke patients. The first aim of this study was to investigate whether in ischaemic stroke patients cerebral atrophy, as measured by the 
degree of ventricular enlargement, is associated with presence of WMLs, stroke subtype, or silent brain infarcts. Ventricular enlargement was associated with higher age, male gender, use of diuretics, WMLs, and with silent small deep and territorial infarcts. As ventriculait enlargement in ischaemic stroke patients was associated with WMLs and silent small deep and territorial infarcts, we concluded that ventricular enlargement is merely due to tissue lass and not specifically associated with either small- or large-vessel disease.

In the syndrome of normal pressure hydrocephalus, cerebral ventricular enlargement might be especially associated with periventricular hypodensities on CT. In this syndrome such hypodensities are thought to be the result of leakage of cerebrospinal fluid into the adjacent brain parenchyma. Therefore, we investigated whether periventricular and deep WMLs were both associated with ventricular enlargement, and compared vascular risk factor profiles of patients with deep or periventricular WMLs to gain indirect clues pointing at the alleged distinct pathogenesis in these two types of WMLs. We found that both deep and periventricular WMLs were associated with ventricular enlargement. Furthermore, both types of WMLs were associated with higher age, silent small deep infarcts, and with lacunar stroke compared with cardio-embolic stroke. So, in ischaemic stroke patients deep and periventricular WMLs had similar risk factor profiles and were both related to ventricular enlargement, pointing at a similar, presumably vascular, pathogenesis.

In Chapter 7 parkinsonian signs were studied in ischaemic stroke patients 3 years after the first-ever stroke. Parkinsonian signs in ischaemic stroke patients might be a long-term consequence of cerebral (small-) vessel disease. However, the concept of vascular parkinsonism is still a matter of debate. Certain parkinsonian features are considered to indicate a vascular cause of the parkinsonian syndrome: lower body parkinsonism, lack of resting tremor, marked gait difficulty, and L-dopa unresponsiveness. We examined patients 3 (median, range 1.2-4.7) years after the first-ever ischaemic stroke for presence of parkinsonian signs (bradykinesia, rigidity, tremor, and gait disorder). All patients had a follow-up CT scan of the brain, to study whether the parkinsonian signs were associated with small deep (lacunar) infarcts, WMLs, and/or territorial infarcts. We found one or more parkinsonian signs in $36 \%$ of the patients; $11 \%$ had clinically had parkinsonism (i.e., 2 or more parkinsonian signs). Parkinsonian signs were more frequent in lacunar than in territorial stroke patients: bradykinesia in $45 \%$ and $7 \%$, rigidity in $13 \%$ and $7 \%$, tremor in $6 \%$ and $7 \%$, gait disorder in $16 \%$ and $7 \%$, respectively. Patients with WMLs at study entry $(\mathrm{N}=16)$ were compared with those without $(\mathrm{N}=87)$ : $56 \%$ and $25 \%$ had bradykinesia, $25 \%$ and $8 \%$ rigidity, $25 \%$ and $3 \%$ tremor, $38 \%$ and $8 \%$ gait disorder, respectively. Multivarate regression analysis showed that WMLs at study entry were associated with brady kinesia, gait disorder, and tremor. Bradykinesia was related to lacunar stroke at study entry. We concluded that one third of our stroke patients had one or more parkinsonian signs. Ten percent clinically had a parkinsonian syndrome, that differed from Lewy-body parkinsonism: only a few 
patients had a resting tremor, whereas gait disorder occurred frequently. The parkinsonian signs were associated with lesions caused by cerebral small-vessel disease. Therefore, this study favours a distinct vascular parkinsonian syndrome, which is related to cerebral lesions caused by small-vessel disease.

In Chapter 8 we evaluated the results of this study. The aim of the studies described in this thesis was to investigate clinically whether heterogeneity of cerebral vascular lesions (intracerebral haemorrhage, different types of smal] deep infarcts, and WMLs) coincided with homogeneity as to the underlying type of cerebral vascular disease. It may be concluded that this is largely the case; except for single, symptomatic lacunar infarcts (due to small-vessel atheromatosis) the remaining lesions are caused by arteriolosclerosis. Further study of factors determining the heterogeneity in cerebral lesions remains of utmost importance in aiming to arrive at a better treatment of patients with cerebral small-vessel disease. Furthermore, regarding the progression of WMLs and small deep infarcts, and the morbidity due to vascular parkinsonism, the search for a specific therapeutical option in cerebral small-vessel disease is also an important issue. More knowledge on various aspects of hypertension (e.g., its degree and duration, and the possible influence of genetic factors) in relationship with end-organ (brain) dlamage could lead to such options, as hypertension is probably the most important risk factor in cerebral small-vessel disease. 


\section{Samenvatting}

CVA (cerebro-vasculair accident) is een verzamelnaam voor verschillende soorten hersenbeschadigingen met een vasculaire oorzaak. Elk type CVA wordt gekenmerkt door een specifiek klachtenpatroon, risicofactoren-profiel, pathogenese, therapie, prognose en eventuele gevolgen op de lange termijn. Alvorens men kan komen tot een effectievere preventie van het CVA, is allereerst meer kennis vereist m.b.t. de oorzaken van de verschillende CVA-subtypen. Het feit dat carotis-endarteriëctomie en antistollingstherapie bij bepaalde CVA-subtypen een duidelijke vermindering geven van de kans op een CVA, toont aan dat, effectieve interventie afhankelijk is van kennis m.b.t. de pathogenese en vasculaire risicofactoren-profielen.

Het doel van dit onderzoek was het bestuderen van diverse aspecten van lesies veroorzaakt door pathologie van de kleine hersenarteriën, zoals kleine diepe herseninfarcten, afwijkingen aan de cerebrale witte stof en primaire hersenbloedingen. Ons eerste doel was te bepalen of al deze verschillende lesies veroorzaakt worden door een gelijksoortige beschadiging van de kleine hersenarteriën. Voorheen zijn er reeds aanwijzingen gevonden dat dit waarschijnlijk niet zo is. Bij autopsie-studies van patiënten met een primaire hersenbloeding is een specifieke afwijking aan de kleine hersenarteriën, genaamd arteriolosclerose, gevonden. Bij kleine diepe herseninfarcten zijn er twee verschillende vaatafwijkingen gevonden: arteriolosclerose bij multiple, meestal asymptomatische kleine diepe herseninfarcten en microatheromatose bij de wat grotere symptomatische herseninfarcten. Ofschoon er bij afwijkingen aan de cerebrale witte stof diverse pathologische veranderingen zijn gevonden, wordt arteriolosclerose als de onderliggende vaatpathologie beschouwd. Een ander doel van deze studie was het bestuderen van mogelijke gevolgen op de lange termijn van pathologie van de kleme hersenarteriën, zoals hersenatrofie en vasculair parkinsonisme.

In Hoofdstuk 2 werden de risicofactoren-profielen vergeleken van patiënten met een primaire hersenbloeding, een klein diep herseninfarct of een territoriaal herseninfarct. Hierbij werd aangenomen dat de profielen van cle risicofactoren een aanduiding kunnen zijn van de onderliggende vaatpathologie. Zowel een voorgeschiedenis van ischemische hartziekte als diabetes mellitus bleken vaker bij beide typen herseninfarcten woor te komen dan bij primaire hersenbloedingen. Hoge bloeddruk was niet specifiek geassocieerd met een bepaald type CVA. Deze verschillen in vasculaire risicofactoren vormen cen extra atuwijzing dat het type pathologie van de kleine hersenarteriën bij primaire hersenbloedingen nief overeenkomt met dat bij de meerderheid van de kleine diepe herseninfarcten. 
In Hoofdstuk 3 werd de progressie in de tijd bestudeerd van cerebrale witte stof afwijkingen en van het aantal kleine diepe en territoriale herseninfarcten bij CVA-patiënten. Tevens werd de hypothese getest dat witte stof afwijkingen geassocieerd zijn met kleine diepe infarcten. We hebben een vervolgstudie gedaan bij een groep van 107 patiënten met een herseninfarct. Bij deze patiënten werd 3 jaar (mediaan) na het eerste herseninfarct opnieuw een computed tomographic (CT) scan gemaakt. De witte stof afwijkingen bleken bij $26 \%$ van de patiënten te zijn toegenomen. Deze progressie hing significant samen met symptomatische kleine diepe herseninfarcten, asymptomatische kleine diepe herseninfarcten bij het begin van deze studie, een hogere leeftijd en met een langere vervolgduur. We vonden bij $38 \%$ van de patiënten een toegenomen aantal kleine diepe herseninfarcten. Deze progressie was geassocieerd met symptomatische kleine diepe infarcten bij het begin van de studie en met een langere vervolgduur. Progressie van zowel witte stof afwijkingen als kleine diepe infarcten, kwam bij $16 \%$ van de patiënten woor, en hing samen met zowel symptomatische als asymptomatische kleine diepe herseninfarcten bij het begin van de studie en met een langere vervolgduur. Hei aantal territoriale herseninfarcten steeg bij $13 \%$ van de patiënten. Deze toename was geassocieerd met symptomatische territoriale infarcten bij het begin van de studie en met een voorgeschiedenis van ischemische hartziekte.

De aanzienlijke progressie van witte stof afwijkingen en kleine diepe herseninfarcten die vooral voorkwam bij patiënten met een symptomatisch klein diep infarct toont aan dat zowel witte stof afwijkingen als kleine diepe herseninfarcten weroorzaakt worden door een aandoening van de kleine hersenarteriën, die progressief is ondanks de standaardbehandeling voor het herseninfarct.

In Hoofdstuk 4 werd de hypothese getest dat witte stof afwijkingen vooral geassocieerd zijn met multiple, meestal asymptomatische kleine diepe herseninfarcten. We hebben bij 960 patiënten met een eerste herseninfarct de incidentie van witte stof afwijkingen bestudeerd. Dit betrof 332 patiënten met een klein diep herseninfarct, 213 met een cardiowembolisch territoriaal infarct en 415 met een atherothrombotisch territoriaal infarct. Tevens werd de relatie van witte stof afwijkingen met vasculaire risicofactoren, en met symptomatische en asymptomatische infarcten onderzocht. Van alle CVA-patiënten had $24 \%$ witte stof afwijkingen. Deze witte stof afwijkingen waren geassocieerd met hogere leeftijd en met zowel symptomatische als (vooral) asymptomatische kleine diepe herseninfarcten. Verder hingen de witte stof afwijkingen samen met asymptomatische territoriale infarcten bij patiënten met een atherothrombotisch territoriaal infarct. We conchdeerden hieruit dat deze bevindingen de hypothese ondersteunen dat witte stof afwijkingen en multiple, meestal asymptomatische kleine diepe infarcten door dezelfde vaatafwijking veroorzaakt worden, namelijk door arteriolosclerose. 
Omdat we ons tot doel hadden gesteld te onderzoeken of hersenatrofie bij CVA-patienten samenhangt met witte stof afwijkingen en herseninfarcten, hebben we eerst de betrouwbaarheid van twee atrofie-metingen op CT scans bestudeerd in Hoofdstuk 5 . Zowel de bicaudate ratio (BCR) als de ratio van de fissura Sylvil (SFR) werden bij 20 CT scans van patiënten met een herseninfarct gemeten door 3 onderzoekers. De "intraclass correlation coefficient" van de BCR-metingen bedroeg 0.82 (95\% betrouwbaarheidsinterval $0.75-0.94$ ), terwijl deze bij de SFR-metingen 0.69 (95\% betrouwbaarheidsinterval $0.57-0.89$ ) bedroeg. De spreiding van de "Pearson correlation coefficients" berekend voor alle paren van onderzoekers was kleiner bij de metingen van de BCR (0.89-0.92), dan bij die van de SFR (0.66-0.84). Concluderend kunnen we stellen dat de avereenkomst tussen de onderzoekers bij de BCR-metingen witstekend was en bij de SFR-metingen matig.

In Hoofdstuk 6 worden de resultaten weergegeven van de hersenatrofie-studie. Bij 917 patiënten met een eerste herseninfarct werd hersenatrofie gemeten m.b.v. de BCR als maat voor de ventrikelgrootte. Het eerste doel van deze studie was te onderzoeken of hersenatrofie bij patiënten met een herseninfarct samenhangt met de aanwezigheid van witte stof afwijkingen, een bepaald type herseninfarct, en/of asymptomatische herseninfarcten. Toename van de ventrikelgrootte was geassocieerd met hogere leeftijd, mannelijk geslacht, gebruil van diuretica, witte stof afwijkingen en met asymptomatische kleine diepe en territoriale herseninfarcten. Gezien de associatie van toename van de ventrikelgrootte met witte stof afwijkingen en asymptomatische kleine diepe en territoriale herseninfarcten, hebben we geconcludeerd dat toename van de ventrikelgrootte puur te wijten is aan weefselverlies en niet specifiek samenhangt met pathologie van de grote of kleine hersenarteriën.

Bij het syndroom van de normale druk hydrocephalus, worden zowel toename van de ventrikelgrootte als periventriculaire hypodensiteiten gevonden op CT. Men neemt aan dat bij de normale druk hydrocephalus deze periventriculaire hypodensiteiten het gevolg zijn van lekkage van liquor cerebrospinalis in het aangrenzende hersenparenchym. Wij hobben onderzocht of zowel periventriculaire ais diepe witte stof afwijkingen bij herseninfarctpatiënten samenhangen met toename van de ventrikelgrootte. Daarnaast werden de vasculaire risicofactoren vergeleken van patiënten met diepe of periventriculaire witte stof afwijkingen on indirecte aanwijzingen te vinden voor de mogelijk verschillende pathogenese bij deze twee localisaties van witte stof afwijkingen. Zowel diepe als periventriculaire witte stof afwijkingen bleken samen te hangen met toename van de ventrikelgrootte. Verder waren beide localisaties van witte stof afwijkingen geassocieerd met hogere leefijd, asymptomatische kleine diepe herseninfarcten en met symptomatische kieine diepe infarcten vergeleken met cardio-embolisehe territoriale herseninfarcten. We mogen hieruit conchnderen dat diepe en periventriculaire witte stof afwijkingen vergelijkbare risicofactorenprofielen hebben bij patiënten met een herseninfarct en tevens dat beiden gerelateerd zijn aan een toename wan de ventrikelgrootte. Dit laatste maakt het warschijnlijker dati aan 
beiden een gelijksoortige, vasculaire pathogenese ten grondslag ligt.

In Hoofdstuk $7 x$ ijn de resulltaten beschreven van een onderzoek naar het vóórkomen van symptomen van parkinsonisme bij patiënten 3 jaar na een eerste herseninfaret. Parkinsonsymptomen bij CVA-patiënten zijn mogelijk een laat gevolg van pathologie van de (kleine) hersenarteriën. Het concept van vasculair parkinsonisme is echter nog omstreden. Bepaalde parkinson-symptomen zouden vaker voorkomen als het parkinsonisme een vasculaire oorzaak heeft: loopstoornissien, het ontbreken van een rusttremor, het overwegen van symptomen aan de benen en niet aan de armen, en het ontbreken van een gunstig effect van L-dopa. Wij heblen patiënten 3 (mediaan, spreiding 1.2-4.7) jaar na het eerste herseninfarct onderzacht op het vóórkomen van parkinson-symptomen (bradykinesie, rigiditeit, tremor, en loopstoornissen). Alle patiënten ondergingen een vervolg CT scan van de hersenen, om te bestuderen of de parkinson-symptomen geassocieerd waren met kleine diepe herseninfarcten, witte stof afwijkingen en/of territoriale herseninfarcten. Parkinsonsymptomen bleken bij $36 \%$ van de patiënten voor te komen; $11 \%$ had klinisch een parkinsonsyndroom (d.w.z. 2 of meer parkinson-symptomen). Parkinson-symptomen kwamen meer voor bij patiënten met een klein diep, dan met een territoriaal infarct: bradykinesie bij respectievelijk $45 \%$ en $7 \%$, rigiditeit bij $13 \%$ en $7 \%$, tremor bij $6 \%$ en $7 \%$, cen loopstoornis bij $16 \%$ en $7 \%$. Patiënten met witte stof afwijkingen bij het begin van de studie $(\mathrm{N}=16)$ werden vervolgens vergeleken met die zonder $(\mathrm{N}=87)$ : respectievelijk $56 \%$ en $25 \%$ had bradykinesie, $25 \%$ en $8 \%$ rigiditeit, $25 \%$ en $3 \%$ tremor, en $38 \%$ en $8 \%$ had een loopstoornis. Bij multivariate regressie analyse bleek dat witte stof afwijkingen bij het begin van de studie geassocieerd waren met bradykinesie, loopstoornissen en tremor. Bradykinesie hing tevens samen met kleine diepe herseninfarcten bij het begin van de studie. Concluderend kunnen we stellen dat een derde van de patiënten met een herseninfarct een of meer parkinson-symptomen had. Tien procent had klinisch een parkinson-syndroom, dat verschilde t.o.v. Lewy-body parkinsonisme: slednts weinig patiënten hadden een rusttremor, terwijl een loopstoomis frequent voorkwam. De parkinson-symptomen waren geassocieerd met lesies veroorzaakt door pathologie aan de kleine hersenarteriën. Al met al ondersteunt. deze studie het bestaan van een parkinson-syndroom van vasculaire origine, samenhangend met lesies veroorzaakt door pathologie van de kleine hersenarteriën.

In Hoofdstuk 8 hebben we de resultaten van deze studie nader beschouwd. Het doel van de studies die beschreven zijn in dit proefschrift was om met klinische parameters te onderzoken of een aantal vasculaire lesies in de hersenen (primaire hersenbloedingen, verschillende typen kleine diepe herseninfarcten en witte stof afwijkingen) door dezelfde soort pathologie van de kleine hersenarteriën veroorzaakt worden. We mogen concluderen dat. dit grotendeels het geval is; met uitzondering van de solitaire, symptomatische kleine diepe herseninfarcten (veroorzalkt door microatheromatose) worden de overige lesies veroorzaakt 
door arteriolosclerose. Er zijn zeker nog meer studies nodig om te bepalen welke factoren van inwloed zijn op het ontstaan vam al deze verschillende lesies in de hersenen. Hopelijk zal dit leiden tot een betere therapie voor patiënten met pathologie van de kleine hersenarterièn. Dit is van belang met het oog op de progressie van witte stof afwijkingen en kleine diepe herseninfarcten en de morbiditeit die veroorzaakt wordt door het vasculaire parkinson-syndroom. Om betere therapeutische opties te verkrijgen is vooral meer kennis nodig van de verschillende aspecten van hypertensie (b.v. de ernst, duur de mogelijke invloed van genetische factoren) in relatie tot eind-orgaan schade (b.v. aan de hersenen), aangezien hypertensie waarschijnlijk de belangrijkste risicofactor is bij pathollogie wan de kleine hersenarteriën. 


\section{References}

1. Anderson JR. Blood vessels and lymphatics. In: Anderson JR, ed. Murr "s textbook of pathology. 11th ed. London: Edward Arnold; 1981:360-395.

2. Antiplatelet Trialists' Collaboration. Collaborative overview of randomised trials of antiplatelet therapy. I: Prevention of death, myocardial infarction, and stroke by prolonged antiplatelet therapy in varions categories of patients. BMJ. 1994,308:81106.

3. Awad IA, Johnson PC, Spetzler RF, Hodak JA. Incidental subcortical lesions identified on magnetic resonance imaging in the elderly. II. Postmortem pathological correlations. Stroke 1986;17:1090-1097.

4. Awad IA, Spetzler RF, Hodak JA, Awad CA, Carey R. Incidental subcortical Lesions identified on magnetic resonance imaging in the elderly. I. Correlation with age and cerebrovascular risk factors. Stroke. 1986;17:1084-1089.

5. Awada A, Omojola MF. Leuko-araiosis and stroke: a case-control study. Acta Newrol Scand. 1996;94:415-418.

6. Babikian V, Ropper AH. Binswanger's disease: a review. Stroke. 1987;18:2-12.

7. Baloh RW, Vinters HV. White matter lesions and disequilibrium in older people. II. Clinicopathologic correlation. Arch Neurol. 1995;52:975-981.

8. Baloh RW, Yue Q, Socotch TM, Jacobson KM. White matter lesions and disequilibrium in older people. I. Case-control comparison. Arch Neurol. 1995;52:970 974.

9. Bamford J, Sandercock P, Dennis M, Burn J, Warlow C. Classification and natural history of dinically identifable subtypes of cerebral infarction. Lancel. 1991;337:1521 1526 .

10. Bamford J, Sandercock $P$, Jones $L$, Warlow $C$. The natural history of lacanar infarction: the Oxfordshire Community Stroke Project. Stroke 1987;18:545-551.

11. Bamford JM, Warlow CP. Evolution and testing of the lacunar hypothesis. Stroke. 1988;19:1074-1082.

12. Bennett DA, Gilley DW, Wilson RS, Huckman MS, Fox JH. Clinical correlates of high signal lesions on magnetic resonance imaging in Aluheimer's discase. I Neurol. $1992 ; 239: 186-190$.

13. Bergman L, Van der Meulen JHP, Limburg M, Habbena JDF. Costs of medical care after first-ever stroke in The Netherlands. Stroke. 1995;26:1830-1836. 
14. Bogousslavsky J, Gastillo V, Kumral E, Henriques I, Van Melle G. Stroke subtypes and hypertension. Primary hemorrhage vs infarction, large- vs small-artery disease. Atch Neirol. 1996;53:265-269.

15. Bogousslawsky I, Regli F, Uske A. Leukoencephalopathy in patients with ischemic stroke. Stroke. 1987;18:896-899.

16. Boiten J, Lodder J. Isolated monoparesis is usually caused by superficial infarction. Cerebrovasc Dis. 1991;1:337-340.

17. Boiten $J$, Lodder J. Lacunar infarcts. Pathogenesis and validity of the clinical syndromes. Stroke. 1991;22:1374-1378.

18. Boiten J, Lodder J. Large striatocapsular infarcts: clinical presentation and pathogenesis in comparison with lacunar and cortical infarcts. Acto Neurol Scand. 1992;86:298303.

19. Boiten J, Lodder J. Prognosis for survival, handicap and recurrence of stroke in lacunar and superficial infarction. Cerebrovasc Dis. 1993;3:221-226.

20. Boiten J, Lodder J, Kessels $F$. Two clinically distinct lacunar infarct entities? A hypothesis. Stroke. 1993;24:652-656.

21. Boiten J, Rothwell PM, Slattery J, Warlow CP. Frequency and degree of carotid stenosis in small centrum ovale infarcts as compared to lacunar infarcts. Cerebrovasc Dis. 1997;7:138-143.

22. Boiten J, Rothwell PM, Slattery J, Warlow CP. Ischaemic lacunar stroke in the European Carotid Surgery Trial. Cerebrovase Dis. 1996;6:281-287.

23. Boon $A$, Lodder J, Heuts-van Raak L, Kessels F. Silent brain infarcts in 755 consecutive patients with a first-ever supratentorial ischemic stroke: Relationship with index-stroke subtype, vascular risk factors, and mortality. Stroke. 1994;25:2384-2390.

24. Bortz J. Statistik fuer Sozialwissenschaftler. Berlin: Springer-Verlag; 1993.

25. Bots ML, Grobbee DE, Hofman A. High blood pressure in the elderly. Epidemiol Rev. $1991 ; 13: 294-314$.

26. Bots ML, Van Swieten JC, Breteler MM, De Jong PT, Van Gijn J, Hofman A, Grobbee DE. Cerebral white matter lesions and atherosclerosis in the Rotterdam Study. Lancet. 1993;341:1232-1237.

27. Braffman BH, Zimmerman RA, Trojanowski JQ, Gonatas NK, Hickey WF, Schlaepfer WW. Bruin MR: pathologic correlation with gross and histopathology. 1. Lacunar infarction and Virchow-Robin spaces. Am $J$ Roentgenol. 1988;151:551-558.

28. Braffman BH, Zimmerman RA, Trojanowski JQ, Gonatas NK, Hickey WF, Schlaepler WW. Brain MR: pathologic correlation with grass and histopathology. 2. Hyperintense white matter foci in the elderly. Am $J$ Roentgenol. 1988;151:559-566.

29. Breteler MM, Van Amerongen NM, Van Swieten JC, Claus JJ, Grobbee DE, Van Gijn J, Hofman A, Van Harskamp F. Cognitive correlates of ventricular enlargement and cerebral white matter lesions on magnetic resonance imaging. The Rotterdam 
Study. Stroke. 1994;25:1109-1115.

30. Breteler MM, Van Sweten JC, Bots ML, Grobbee DE, Claus JJ, Van den Hout JH, Van Harskamp $\mathbb{F}$, Tanghe HL, De Jong PT, Van Gijn „, et al. Cerebral white matter lesions, vascular risk factors, and cognitive function in apulation-based study: the Rotterdam Study. Neurology. 1994;44:1246-1252.

31. Brun A, Englund E. A white matter disorder in dementia of the Alzheimer type: a pathoanatomical study. Arn Neurol. 1986;19:253-262.

32. Cadelo M, Inzitari D, Pracucci G, Mascalchi M. Predictors of leukoaraiosis in elderly neurological patients. Cerebrovasc Dis. 1991;1:345-351.

33. Caplan L. Intracerebral hemorrhage revisited. Neurology. 1988;38:624-627.

34. Caplan LR. Intracranial branch atheromatous disease: a neglected, understudied, and underused concept. Neurology. 1989;39:1246-1250.

35. Caplan LR, Hier DB, D'Cruz I. Cerebral embolism in the Michael Reese Stroke Registry. Stroke. 1983;14:530-536.

36. Caplan LR, Schoene WC. Clinical features of subcortical arteriosclerotic encephalopathy (Binswanger disease). Neurology. 1978;28:1206-1215.

37. Castillo J, Rodriguez JR, Corredera E, Alvarex JM, Purmar JM, Noya M. White matter high-signal areas on MRI associated with chronic hypoxia. Eur J Neurol. $1996 ; 3: 533-538$.

38. Claus JJ, Breteler MMB, Hasan D, Krenning EP, Bots ML, Grobbee DE, Van Swieten JC, Van Harskamp F, Hofman A. Vascular risk factors, atherosclerosis, cerebral white matter lesions and cerebral perfusion in a population-based study. Eur $J$ Nucl Med. $1996 ; 23: 675-682$.

39. Coffey CE, Wilkinson WE, Parashos IA, Soady SA, Sullivan RJ, Patterson LJ, Figiel GS, Webb MC, Spritzer CE, Djang WT. Quantitative cerebral anatomy of the aging human brain: a cross-sectional study using magnetic resonance imaging. Neurology. $1992 ; 42: 527-536$

40. Critchley M. Arteriosclerotic parkinsonism. Brain. 1929;52:23-83.

41. De Renck J, Crevits L, De Coster W, Sieben G, Vander Eectren H. Pahogenesis of Binswanger chronic progressive subcortical encephalopathy. Neurology. 1980,30:920928.

42. DeCarli C, Murphy DG, Tranh M, Grady CL, Haxby JV, Gillette JA, Salerno JA, Gonzales-Aviles A, Horwitz B, Rapoport SI, Schapiro MB. The effect of white matter hyperintensity volume on brain structure, cognitive performance, and cercbral metabolism of glucose in 51 healthy adults. Neurology. 1995:45:2077-2084.

43. Diener HC, Cunha L, Forbes C, Sivenins f, Smets P, Lowonthal A. European Stroke Prevention Study. 2. Dipyridamole and acetylsalicylic acid in the secondary prevention of stroke. I Neturol Sci. 1996;143:1-13.

44. Dubinsky RM, Jankovic J. Progressive supranuclear palsy and a multi-infarct state. 
Neurology. 1987;37:570-576.

45. EAFT Study Group. Secondary prevention in non-rheumatic atrial fibrillation after transient ischaemic attack or minor stroke. Lancet. 1993;342:1255-1262.

46. Earmest MP, Heaton RK, Wilkinson WE, Manke WF. Cortical atrophy, ventricular enlargement and intellectual impairment in the aged. Neurology. 1979;29:1138-1143.

47. European Carotid Surgery Trialists' Collaborative Group. MRC European Carotid Surgery Trial: interim results for symptomatic patients with severe (70-99\%) or with mild $(0-29 \%)$ carotid stenosis. Lancet. 1991;337:1235-1243.

48. Evers SMAA, Engel GL, Ament AJHA. Cost of stroke in The Netherlands from a societal perspective. Stroke. 1997;28:1375-1381.

49. Fazekas F. Magnetic resonance signal abnormalities in asymptomatic individuals: their incidence and functional correlates. Eur Neurol. 1989;29:164-168.

50. Fazekas F, Chawluk JB, Alavi A, Hurtig HI, Zimmerman RA. MR signal abnormalities at $1.5 \mathrm{~T}$ in Alzheimer"s dementia and normal aging. Am $J$ Roentgenol. $1987 ; 149: 35\rfloor-356$.

51. Fazekas F, Kleinert R, Offembacher $H$, Schmidt R, Kleinert G, Payer F, Radner H, Lechner H. Pathologic correlates of incidental MRI white matter signal hyperintensities. Neurology. 1993;43:1683-1689.

52. Fazekas F, Niederkorn K, Schmidt $\mathbb{R}$, Offenbacher H, Horner S, Bertha $G$, Lechner $\mathrm{H}$. White matter signal abnormalities in normal individuals: correlation with carotid ultrasonography, cerebral blood flow measurements, and cerebrovascular risk factors. Stroke. 1988;19:1285-1288.

53. Feldmann E. Intracerebral hemorrhage. Stroke. 1991;22:684-691.

54. Fern R, Ransom BR, Waxman SG. White matter stroke: autoprotective mechanisms with therapeutic implications. Cerebrovasc Dis. 1996;6:59-65.

55. Fisher CM. The arterial lesions underlying lacunes. Acta Neuropathol. 1969;12:1-15.

56. Fisher CM. Binswanger's encephalopathy: a review. I Nextrol. 1989;236:65-79.

57. Fisher CM. Capsular infarcts: the undenlying vascular lesions. Arch Neurol. 1979;36:65-73.

58. Fisher CM. Lacunar infarcts - a review. Cerebrovasc Dis. 1991;1:311-320.

59. Fisher CM. Lacunar strokes and infarcts: a review. Neurology. 1982;32:871-876.

60. Fisher CM. Pathological observations in hypertensive cerebral hemorrhage. $J$ Neuropathol Exp Neurol 1971;30:536-550.

61. FitzGerald PM, Jankovic J. Lower body parkinsonism: evidence for vascular etiology. Mov Disord. 1989;4:249-260.

62. Foulkes MA, Woll PA, Price TR, Mohr JP, Hier DB. The Stroke Data Bank: design, methods, and baseline characteristics. Stroke. 1988;19:547-554.

63. Fulkuda H, Kobayashi S, Okada K, Tsunematsu $T$. Frontal white matter lesions and dementia in lacunar infarction. Stroke. 1990;21:1143-1149. 
64. Furuta A, Ishii N, Nishihara $Y$, Horie A. Mledulary arteries in aging and dementia. Stroke. 1991;22:442-446.

65. George AE. Chronic communicating hydrocephalus and periventricular white matter disease: a debate with regard to cause and effect. Am I Neuroradiol 1991;12:42-44.

66. George AE, De Leon MJ, Gentes CI, Miller J, London E, Budzilovich GN, Ferris $\mathrm{S}$, Chase $\mathrm{N}$. Leukoencephalopathy in normal and pathologic aging: 1. C $\mathrm{C}$ of brain lucencies. $A J N R, 1986 ; 7: 561-566$.

67. Ghika JA, Bogousslavsky J, Regli F. Deep perforators from the carotid system. Template of the vascular territories. Arch Neurol. 1990;47:1047-1100.

68. Gibb WRG, Lees AJ. The relevance of the Lewy body to the pathogenesis of idiopathic Parkinson's disease. I Neurol Neurosurg Psychiatry. 1988;51:745-752.

69. Gomes F, Dujovny M, Umansky F, Ausman JI, Diaz FG, Ray WJ, Mirchandani HG. Microsurgical anatomy of the recurrent artery of Heubner. J Neurosurg 1984;60;130139.

70. Gomori JM, Steiner I, Melamed E, Cooper G. The assessment of changes in brain volume using combined limear measurements. A CT-scan study. Neuroradiology. $1984 ; 26: 21-24$.

71. Gorelick PB, Chatterjee A, Patel D, Flowerdew G, Dollear W, Taber I, Harris Y. Cranial computed tomographic obserwations in multi-infarct dementia. A controlled study. Stroke. 1992;23:804-811.

72. Goto K, Ishii N, Fukasawa H. Diffuse white-matter disease in the geriatric population. A clinical, neuropathological, and CT study. Radiology. 1981;141:687-695.

73. Gray F, Dubas F, Roullet E, Escourolle R. Lenkoencephalopathy in difuse hemorrhagic cerebral amyloid angiopathy. Ann Neurol. 1985; 18:54-59.

74. Gross CR, Kase CS, Mohr JP, Cunningham SC, Baker WE. Stroke in south Alabama: incidence and diagnostic features. A population based study. Stroke. 1984;15:249-255.

75. Gyldensted C. Measurements of the normal ventricular system and hemispheric sulci of 100 adults with computed tomography. Neuroradiology. 1977;1:4:183192.

76. Hachinski $V$. Preventable senility: a call for action against the vascular dementias. Lancet. 1992;340:645-648.

77. Hachinski VC, Lassen NA, Marshall J. Multi-infarct dementia. A cause of mental deterioration in the elderly, Lancet. 1974;2:207-210.

78. Hachinski VC, Potter P, Merskey H. Leuko-araiosis. Arch Newrol 1987;44:21 233.

79. Hatazawa J, Yamaguch T, Ito M, Yanaura H, Matsuzawa T. Association of lyypertension with increased atrophy of brain matter in the eldedy. I Am Geratr Soc. $1984 ; 32: 370-374$.

80. Haug G. Age and sex dependence of the size of nomal ventricles on computed tomography. Neuraradiology. 1977; 14:201-204.

81. Hénon H, Godefroy O, Lucas C, Pruvo JP, Leys D. Risk factors and loukoaraiosis in 
stroke patients. Acta Neurol Scand. 1996;94:137-144.

82. Werholz K, Heindel W, Rackl A, Neubauer 1, Steinbrich W, Pietrzyk U, ErasmiKorber H, Heiss WD. Regional cerebral blood flow in patients with leuko-araiosis and atherosclerotic carotid artery disease. Arch Neurol. 1990;47:392-396.

83. Hershey $\mathrm{LA}$, Modic MT, Greenough $\mathrm{PG}$, Jaffe $\mathrm{DF}$. Magnetic resonance imaging in vascular dementia. Neurology. 1987;37:29-36.

84. Hier DB, Foulkes MA, Swiontoniowski M, Sacco RL, Gorelick PB, Mohr JP, Price $\mathrm{TR}_{\mathrm{f}}$ Wolf PA. Stroke recurrence within 2 years after ischemic infarction. Stroke. $1991 ; 22: 155-161$.

85. Hijdra A, Derix MM, Teunisse S, Van Gool WA, Kwa IH. Dementia after stroke. Stroke. 1991:22:416.

86. Hijclra A, Verbeeten B, Jr. Leukoaraiosis and ventricular enlargement in patients with ischemic stroke. Stroke. $1991 ; 22: 447-450$.

87. Hijdra A, Verbeeten B, Jr., Verhulst JA. Relation of leukoaraiosis to lesion type in stroke patients. Stroke. 1990;21:890-894.

88. Inzelberg R, Bornstein NM, Reider I, Korczyn AD. Basal ganglia lacunes and parkinsonism. Neuroepidemiology. 1994;13:108-112.

89. Inzitari D, Cadelo M, Marranci ML, Pracucci G, Pantoni $\mathbb{L}$. Vascular deaths in elderly neurological patients with leukoaraiosis. I Neurol Neurosurg Psychiatry. 1997;62:177181.

90. Inzitari D, Diaz F, Fox A, Hachinski VC, Steingart A, Lau C, Donall A, Wade J, Mulic H, Merskey H. Vascular risk factors and leuko-araiosis. Arch Neurol. $1987,44: 42-47$.

91. Inzitari D, Giordano GP, Ancona AL, Pracucci G, Mascalchi M, Amaducci L. Leukoaraiosis, intracerebral hemorrhage, and arterial hypertension. Stroke. $1990 ; 21: 1419-1423$

92. Isaka $\mathrm{Y}$, Nagano K, Narita M, Ashida K, Imaizumi M. High signal intensity on T2 waighted magnetic resonance imaging and cerebral hemodynamic reserve in carotid occlusive disease. Stroke. 1997;28:354-357.

93. Isaka Y, Okamoto M, Ashida K, Imaizumi M. Decreased cerebrovascular dilatory capacity in subjects with asymptomatic periventricular hyperintensities. Stroke. $1994 ; 25: 375-381$.

94. Ishii $N$, Nishihara $Y$, Imamura " $T$. Why do frontal lobe symptoms predominate in wascular dementia with lacunes? Neurology. 1986;36:340-345.

95. Janota I, Mirsen TR, Hachinski VC, Lee DH, Merskey H. Neuropathologic correlates of lento-araiosis. Arch Neurol. 1989;46:1124-1128.

96. Jørgensen HS, Nakayama H, Raxschou HO, Olsen TS. Leukoaraiosis in stroke patients. The Copenhagen Stroke Study. Stroke. 1995;26:588-592.

97. Kappelle LJ, Koudstad PJ, Van Gijn J, Ramos LMP, Keunen JEE. Carotid angio- 
graphy in patients with lacunar infarction. A prospective study. Stroke. 1988:19:1093 1096.

98. Kawamura J, Meyer JS, Ichijo M, Kobari M, Terayama Y, Weathers S. Correlations of leuko-araiosis with cerebral atrophy and perfusion in elderly nomal subjects and demented patients. J Neurol Neurosurg Psychiatry. 1993;56:182-187.

99. Kertesz A, Black SE, Tokar G, Benke T, Carr T, Nicholson L. Periventricular and subcortical hyperintensities on magnetic resonance imaging. Rims, caps, and unidentified bright objects. Arch Neurol. 1988;45:404-408.

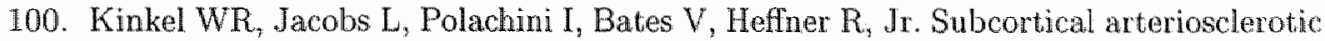
encephalopathy (Binswanger's disease). Computed tomographic, nuclear magnetic resonance, and clinical correlations. Arch Neurol. 1985;42:951-959.

101. Kirkpatrick $\mathbb{} \mathrm{B}$, Hayman LA. White-mater lesions in MR imaging of clinically healthy brains of elderly subjects: possible pathologic basis, Radrolog\%. 1987;162:509511.

102. Kobari M, Fukuuchi $Y$, Shinohara T, Obara K, Nogawa S. Levodopa-induced local cerebral blood flow changes in Parkinson's disease and related disorders. J Neurol. Sc: 1995;128:212-218.

103. Kobari M, Meyer JS, Ichijo M. Leuko-araiosis, cerebral atrophy, and cerebral perfusion in normal aging. Arch Neurol. 1990;47:161-165.

104. Kobayashi $\mathrm{S}$, Okada $\mathrm{K}$, Yamashita $\mathrm{K}$. Incidence of silent lacumar lesion in normal adults and its relation to cerebral blood flow and risk factors. Stroke. 1991;22:13791383.

105. Kozachuk WE, DeCarli C, Schapiro MB, Wagner EE, Rapoport SI, Horwitz B. White matter hyperintensities in dementia of Alzheimer's type and in healthy subjects without cerebrovascular risk factors. A magnetic resonance imaging study. Arch Newrol. $1990 ; 47: 1306-1310$.

106. Krauss JK, Regel JP, Vach W, Droste DW, Borremans JJ, Mergner T. Vascular risk factors and arteriosclerotic disease in idiopathic normal-pressure hydrocephalus of the elderly. Stroke. 1996;27:24-29.

107. Landi $\mathrm{G}$, Cella $\mathrm{E}$, Boccardi $\mathrm{E}_{\text {, }} \mathrm{Musicco} \mathrm{M}$. Lacunar versus non-lacunar infarcts: pathogenetic and prognostic differences. I Newrol Neurosury Psychatry. 1992;55:441. 445.

108. Lee D, Fox A, Vinuela F, Pelz D, Lau C, Donald A, Merskey H. Interobserver wariation in computed tomography of the brain. Arch Neurol. 1987,44:30-31.

109. Leonardi M, Ferro S, Agati R. Fiorani L, Righini A, Cristina E, D'Alessandro R. Interobserver variability in CT assessment of brain atrophy. Neuroradioloyy. 1994:36:17 19.

110. Leys D, Pruwo JP, Parent M, Vermersch P, Soetaert G, Steinling M, Delacourte $A$, Defossez A, Rapoport A, Clarisse I, et al. Could Wallerian degeneration contribute to "leukomaraiosis" in subjects free of ary vascular disonder? I Neurol Neurouarg 
Psychiatry. 1991;54:46-50.

111. Leys D, Soetaert G, Petit H, Fauquette A, Pruvo JP, Steinling M. Periventricular and white matter magnetic resonance imaging hyperintensities do not differ between Alzheirner's disease and normal aging. Arch Neurol. 1990;47:524-527.

112. Liao D, Cooper L, Cai J, Toole JF, Bryan NR, Hutchinson RG, Tyroler HA. Presence and severity of cerebral white matter lesions and hypertension, its treatment, and its control. The ARIC Study. Atherosclerosis Risk in Communities Study. Stroke. $1996 ; 27: 2262-2270$.

113. Lindgren A, Roijer A, Rudling O, Norrving B, Larsson EM, Eskilsson J, Wallin L, Olsson $\mathrm{B}$, Johansson $\mathrm{BB}$. Cerebral lesions on magnetic resonance imaging, heart disease, and vascular risk factors in subjects without stroke. A population-based study. Stroke. 1994;25:929-934.

114. Lodder J, Bamford JM, Sandercock PA, Jones LN, Warlow CP. Are hypertension or cardiac embolism likely causes of lacunar infarction? Stroke. 1990;21:375-381.

115. Loeb C, Gandolfo C, Bino G. Intellectual impairment and cerebral lesions in multiple cerebral infarcts. A clinical-computed tomography study. Stroke. 1988;19:560-565.

116. Loeb C, Gandolfo C, Croce R, Conti M. Dementia associated with lacunar infarction. Stroke. 1992;23:1225-1229.

117. Loizou LA, Jefferson JM, Smith WT. Subcortical arteriosclerotic encephalopathy (Binswanger's type) and cortical infarcts in a young normotensive patient. $J$ Neurol Neurosurg Psychiatry. 1982;45:409-417.

118. Loizou $L A$, Kendall BE, Marshall J. Subcortical arteriosclerotic encephalopathy: a clinical and radiological investigation. J Neurol Neurosurg Psychiatry. 1981;44:294304.

119. Looman SJ, Bots ML, Hofman A, Koudstaal PJ, Grobbee DE. Beroerte bij ouderen: prevalentie en opnamefrequentie; het ERGO-onderzoek. Ned Tijdschr Geneesslid. 1996;140:312-316.

120. Lopez OL, Becker JT, Jungreis CA, Rezek D, Estol C, Boller F, DeKosky ST. Computed tomography-but not magnetic resonance imaging-identified periventricular white-matter lesions predict symptomatic cerebrovascular disease in probable Alzheimer's disease. Arch Neurol. 1995;52:659-664.

121. MacKay S, Meyerhof DJ, Constans JM, Norman D, Fein G, Weiner MW, Regional gray and white matter metabolite differences in subjects with $\mathrm{AD}$, with subcortical ischemic vascular dementia, and elderly controls with $1 \mathrm{H}$ magnetic resonance spectroscopic imaging. Arch Neurol. 1996;53:167-174.

122. Manolio TA, Kronmal RA, Burke GL, Poirier V, O'Leary DH, Gardin JM, Fried LP, Steinberg EP, Bryan RN. Magnetic resonance abnormalities and cardiovascular disense in older adults. The Cardiovascular Health Study. Stroke. 1994;25:318-327.

123. Marinkovic SV, Milisavljevic MM, Kovacevic MS. Anastomoses among the thatamo- 
perforating branches of the posterior cerebral artery. Arch Neurol 1986:43:811-814.

124. Marinkovic SV, Milisavijevic MM, Kovacevic MS, Stevic ZD. Perforating branches of the middle cerebral artery. Microanatomy and clinical significance of their intracerebral segments. Stroke. 1985;16:1022-1029.

125. Marshall VG, Bradley WG, Jr., Marshall CE, Bhoopat T, Rhodes RH. Deep white matter infarction: correlation of MR imaging and histopathologic findings. Rodiology. $1988 ; 167: 517-522$.

126. Masdeu JC, Wolfson L, Lantos G, Tobin JN, Grober E, Whipple R, Amerman P. Brain white-matter changes in the elderly prone to falling. Arch Neurol. 1989;46:1292 1296.

127. Mast H, Thompson JL, Lee SH, Mohr JP, Sacco RL. Hypertension and diabetes mellitus as determinants of multiple lacunar infarcts. Stroke. 1995;26:30-33.

128. Meese W, Kluge W, Grumme T, Hopfenmuller W. CT evaluation of the CSF spaces of healthy persons. Neuroradiology. 1980;19:131-136.

129. Meguro $\mathbb{K}$, Hatazawa $J$, Yamaguchi $T$, Itoh $M$, Matsuzawa $T$, Ono S, Miyazawa H, Hishinuma T, Yanai $K$, Sekita $Y$, Yamada K. Cerebral circulation and oxygen metabolism associated with subclinical periventricular hyperintensity as shown by magnetic resonance imaging. Ann Neurol. 1990;28:378-383.

130. Meyer JS, Muramatsu K, Mortel KF, Obara K, Shirai T. Prospective CT confirms differences between vascular and Alzheimer's dementia. Stroke. 1995;26:735-742.

131. Miller VT. Lacunar stroke. A reassessment. Arch Neurol. 1983;40:129-134.

132. Mirsen TR, Lee DH, Wong CJ, Diaz JF, Fox AJ, Hachinski VC, Merskey H. Clinical correlates of white-matter changes on magnetic resonance imaging scans of the brain. Arch Neurol. 1991;48:1015-1021.

133. Mochizuki $Y$, Oishi M, Takasu $T$. Cerebral blood flow in single and multiple lacunar infarctions. Stroke. 1997;28:1458-1460.

134. Mohr JP, Caplan LR, Melski JW, Goldstein RJ, Duncan GW, Kistler JP, Pessin MS, Bleich HL. The Harvard Cooperative Stroke Registry: a prospective registry. Neurology. 1978;28:754-762.

135. Moody DM, Bell MA, Challa VR. Features of the cerebral vascular pattem that prodict vulnerability to perfusion or oxygenation deficiency: an anatomic siludy. A.MNR. $1990 ; 11: 431-439$.

136. Moody DM, Brown WR, Challa VR, Anderson RLl. Peniventriculal venous collagenosis: association with leukoaraiosis. Radiology. 1995;194:469-476.

137. Mumenthaler M. Neurology. Stuttgart: Georg Thieme; 11990 .

138. Murrow RW, Schweiger GD, Kepes JJ, Koller WC. Parkinsonism due to a basal ganglia lacunar state: clinicopathologic correlation. Nourology. 1990;40:897-900.

139. Nakane M, Teraoka A, Asato R, Tamura A. Degeneration of the ipsilateral substantia nigra following cerebral infarction in the striatum. Stroke. 1992;23:328-332.

140. Nelson MDJ, Gonzalez-Gomez I, Gilles FH. Dyke Award. The seareh for human 
telencephalic ventriculofugal arteries. ANNR. 1991;12:215-222.

141. Nicolas JM, Estruch R, Salamero M, Orteu N, Fernandez-Sola J, Sacanella E, UrbanoMarquez A. Brain impaiment in well-nourished chronic alcoholics is related to ethanol intake. Ant Newrol. 1997;41:590-598.

142. Norrving B, Crongvist S. Clinical and radiologic features of lacunar versus nonlacunar mimor stroke. Stroke. 1989;20:59-64.

143. North American Symptomatic Carotid Endarterectomy Trial Collaborators. Beneficial effect of carotid endarterectomy in symptomatic patients with high-grade carotid stenosiss. $N$ Engl J Med. 1991;325:445-453.

144. Nutt JG, Hammenstad JP, Gancher ST. Parkinson's disease: 100 maxims. London: Edward Anold; 1992.

145. Nutt $\mathbb{G}$, Marsden $C D$, Thompson PD. Human walking and higher-level gait disorders, particularly in the elderly. Neurology. 1993;43:268-279.

146. Omae T, Ueda K, Ogata J, Yamaguchi T. Parenchymatous hemorrhage: etiology, pathology and clinical aspects. In: Toole JF, ed. Handbook of Clinical Neurolagy. Vol 10 (54): Vascular diseases Part II. Amsterdam: Elsevier Science Publishers; 1989:287-331.

147. Padovani A, Di Piero V, Bragoni M, Di Biase C, Trasimeni G, Iannili M, Laudani G, Zanette E, Gualdi GF, Lenzi GL. Correlates of leukoaraiosis and ventricular enlargement on magnetic resonance imaging; a study in normal elderly and cerebrovascular patients. Eur J Neurol. 1997;4:15-23.

148. Pasquier F, Leys D, Weerts JGE, Mounier-Vehier F, Barkhof F, Scheltens P. Interand intraobserver reproducibility of cerebral atrophy assessment on MRI scans with hemispheric infarcts. Eur Neurol. 1996;36:268-272.

149. Piccini P, Pavese $N$, Canapicchi $R$, Paoli $C$, Del Dotto P, Puglioli M, Rossi $G$, Bonuccelli U. White matter hyperintensities in Parkinson's disease. Clinical correlations. Arch Neurol 1995;52:191-194.

150. Pujol J Junque $C$, Vendrell P, Capdevila A, Marti-Vilalta JL. Cognitive correlates of ventricular enlargement in vascular patients with leuko-araiosis. Acta Neurol Scand. $1991 ; 84: 237-242$.

151. Pullicino PM, Caplan LR, Hommel M, eds. Cerebral small artery disease. Advances in neturology. Vol 62. New York: Raven press; 1993.

152. Reider-Groswasser I, Bornstein NM, Korczyn AD. Parkinsonism in patients with lacumar intarcts of the basal ganglia. Eur Newrol. 1995;35:46-49.

153. Revesz T, Hawkins CP, Du Boulay EP, Barnard RO, MoDonald WT. Pathological findings correlated with magnetic resonance imaging in subcortical arteriosclerotic encephalopathy (Binswanger's disease). I Neurol Newrosurg Psychiatry. 1989;52:13371344.

154. Rezek DL, Morris JO, Fulling KH, Gado MH. Periventricular white matter lu- 
cencies in senile dementia of the Alwheimer type and in nomal aging: Neurology. $1987 ; 37: 1365-1368$.

155. Roman GC. White matter lesions and normal-pressure hydrocephalus: Binswange: disease or Hakim syndrome? AJNR. 1991;12:40-41.

156. Rosenberg GA, Kornfeld M, Stovring J, Bicknell JM. Subcortical arteriosclerotic encephalopathy (Binswanger): computerized tomography. Neurology. 1979,29:11021106.

157. Rosner SS, Rhoton AL, Jr., Ono M, Barry M. Microsurgical anatomy of the anterior perforating arteries. J Neurosurg. 1984;61:468-485.

158. Sabattini L. Evaluation and measurement of the normal ventricular and subarachnoid spaces by CT. Neuroradiology. 1982;23:1-5.

159. Salerno JA, Murphy DG, Horwitz B, DeCarli C, Haxby JV, Rapoport SI, Schapiro MB. Brain atrophy in hypertension. A volumetric magnetic resonance imaging study. Hypertiension. 1992;20:340-348.

160. Samuelsson M, Lindell D, Olsson GB. Lacunar infarcts: a 1-year clinical and MRI follow-up study. Cerebrovasc Dis. 1994;4:265-272.

161. Scarpelli M, Salvolini U, Diamanti L, Montironi R, Chiaromoni L, Maricoti M. MRI and pathological examination of post-mortem brains: the problem of white matter high signal areas. Neuroradiology. 1994;36:393-398.

162. Scheltens P, Barkhof F, Leys D, Wolters EC, Ravid R, Kamphorst W. Histopathologic: correlates of white matter changes on MRL in Alaheimer's disease and nomal aging. Neurology. 1995;45:883-888.

163. Scheltens P, Pasquier F, Weerts JGE, Barkhof F, Leys D. Qualitative assessment of cerebral atrophy on MRI: inter- and intra-observer reproducibility in dementia and normal aging. Eur Neurol. 1997;37:95-99.

164. Schmal M, Marini C, Carolei A, Di Napoli M, Kessels $\mathbb{E}$, Lodder J. Different vascullar risk factor profiles between small deep infarcts and primary intracerebral hemormage point at different types of underlying small wessel disease. A study from the L'Aquila Stroke Registry. Cerebrovasc Dis. In press.

165. Schmidt R, Fazekas F, Koch M, Kapeller P, Augustin M, Offenbacher H, Fazekas $G$, Lechner $\mathbb{H}$. Magnetic resonance imaging cerebral abnomalities and neuropsychologic test performance in elderly hypertensive subjects. A case-control study. Arch Newrol. $1995 ; 52: 905-910$.

166. Shrout $\mathrm{PE}, \mathrm{Fleiss} \mathbf{J}$. Intraclass correlations: uses in assessing rater reliability. Psychol Bull. $1979 ; 85: 420-428$.

167. Staal A, Meerwaldt JD, Van Dongen KJ, Mulder PGH, Busch HFM. Non-familial degenerative disease and atrophy of brainstem and cerebellum. Clinical and CT data in 47 patients. J Neurol Sci 1990;95:259-269.

168. Steingart $A$, Hachinski $V \mathrm{C}$, Lau $\mathrm{C}$, Fox $\mathrm{AJ}_{\text {, }} \mathrm{Diaz} \mathrm{F}$, Cape R, Lee $\mathrm{D}$, Inzitari $\mathrm{D}$, 
Merskey $\mathrm{H}$. Cognitive and neurologic findings in subjects with diffuse white matter lucencies on computed tomographic scan (leuko-araiosis). Arch Neurol. 1987;44:3235.

169. Steingart $A$, Hachinski $V C$, Lau $C$, Fox AJ, Fox $H$, Lee D, Inzitari D, Merskey $H$. Cognitive and neurologic findings in demented patients with diffuse white matter lucencies on computed tomograplaic scan (leuko-araiosis). Arch Newrol 1987;44:3639.

170. Strassburger TL, Lee HL, Daly EM, Szczepanik J, Krasuski JS, Mentis MJ, Salemo JA, DeCarli $\mathrm{C}$, Schapiro MB, Alexander GE. Interactive effects of age and bypertension on volumes of brain structures. Stroke. 1997;28:1410-1417.

171. Streifler JY, Eliasziw M, Benavente OR, Hachinski VC, Fox AJ, Barnett H. Lack of relationship between leukoaraiosis and carotid artery disease. The North American Symptomatic Carotid Endarterectomy Trial. Arch Neurol. 1995;52:21-24.

172. Sultzer DL, Mahler ME, Cummings JL, Van Gorp WG, Hinkin CH, Brown C. Cortical abnomalities associated with subcortical lesions in vascular dementia. Clinical and position emission tomographic findings. Arch Neurol. 1995;52:773-780.

173. Tanaka $H$, Ueda $Y$, Hayashi M, Date C, Baba T, Yamashita H, Shoji $H$, Tanaka $Y$, Owada K, Detels R. Risk factors for cerebral hemorrhage and cerebral infarction in a Japanese rural community. Stroke. 1982;13:62-73.

174. Tarvonen-Schroder S, Roytta M, Raiha I, Kurki T, Rajala T, Sourander L. Clinical features of leuko-araiosis. I Neurol Neurosury Psychiatry. 1996;60:431-436.

175. Tatemichi TK, Desmond DW, Mayeux R, Paik M, Stern Y, Sano M, Remien $\mathbb{R H}$, Williams JB, Mohr JP, Hauser WA, et al. Dementia after stroke: baseline frequency, risks, and clinical features in a hospitalized cohort. Neurology. 1992;42:1185-1193.

176. Tatemichi TK, Foulkes MA, Mohr JP, Hewitt JR, Hier DB, Price TR, Wolf PA. Dementia in stroke survivors in the Stroke Data Bank cohort. Prevalence, incidence, risk factors, and computed tomographic findings. Stroke. 1990;21:858-866.

17. Tatemichi TK, Paik M, Bagiella E, Desmond DW, Stern Y, Sano M, Hauser WA, Mayeux R. Risk of dementia after stroke in a hospitalized cohort: results of a longitudinal study. Nearology, 1994;44:1885-1891.

178. Tggeler CH, Shi F; Morgan T. Carotid stenosis in lacunar stroke. Stroke. $1991 ; 22: 1124-1128$.

179. Thajeb P. Gait disorders of multi-infarct dementia. CT and clinical correlation. Acta Neurol Sound. 1993;87:239-242.

180. Tolosa ES. Santamaria J. Parkinsonism and basal ganglia infarcts. Neurology. $1.984 ; 34: 1516-1518$.

181. Tomimoto $H$, Akiguchi I, Suenaga $T$, Nishimura M, Wakita $H$, Nakamura $S$, Kimura J. Alterations of the blood-brain barrier and glial cells in white-matter lesioms in cerebrovascular and Alzheimer's disease patients. Stroke. 1996;27:2069-2074. 
182. Vallentine $A R$, Moseley IF, Kendall BE. White matter abnormality in cerebral atw rophy: clinicoradiological correlations. J Neurol Newrosurg Psychiatry. 1980;43:139142.

183. Van der Zwan A, Hillen B, Tulleken CA, Dujovny M, Dragovic L. Variability of the territories of the major cerebral arteries. I Neurosurg. 1992;77:927-940.

184. Van Gijn J, Hijdra A, Wijdicks EF, Vermeulen M, Van Crevel H. Acute hydrocephalus after aneurysmal subarachnoid hemorrhage. J Neurosurg. 1985;63:355-362.

185. Van Merwijk G, Lodder J, Bamford J, Kester AD. How often is non-valvular atrial fibrillation the cause of brain infarction? J Neurol 1990;237:205-207.

186. Van Swieten JC, Geyskes GG, Derix MM, Peeck BM, Ramos LM, Van Latum JC, Van Gijn J. Hypertension in the elderly is associated with white matter lesions and cognitive decline. Ann Neurol. 1991;30:825-830.

187. Van Swieten JC, Van den Hout JH, Van Ketel BA, Hijdra A, Wokka JH, Van Gijn J. Periventricular lesions in the white matter on magnetic resonance imaging in the elderly. A morphometric correlation with arteriolosclerosis and dilated perivascular spaces. Brain. 1991;114:761-774.

188. Van Zagten M, Boiten J, Kessels $\mathrm{F}$, Ladder J. Significant progression of white matter lesions and small deep (lacunar) infarcts in patients with strolie. Arch Neurol. $1996 ; 53: 650-655$.

189. Warlow CP, Dennis MS, Van Gijn J, Hankey GJ, Sandercock PAG, Bamford JM, Wardlaw J. Stroke. A practical guide to management. Oxford: Blackwell Science; 1996.

190. Wood JH. Cerebral blood flow. Physiologic and clinical aspects. New York: McGrawHill Book Company; 1987.

191. Yamaguchi T, Hatazawa J, Kubota K, Abe Y, Fujiwara T, Matsuzawa " T. Correlations between regional cerebral blood flow and age-related brain atrophy: a quantitative study with computed tomography and the xenon-133 inhalation method. I Am Geriatr Soc. 1983:31:412-416.

192. Yamanouchi H, Nagura H. Neurological signs and frontal white matter lewions in vascular parkinsonism. A clinicopathologic study. Stroke. 1997;28:965-969.

193. Ylikoski A, Erkinjuntti T, Raininko R, Sarna S, Sulkava R, Tilwis R. White matter hyperintensities on MRI in the neurologically nondiseased elderly. Stroke. $1995 ; 26: 1171-1177$.

194. Zhang WW, Badonic T, Hoog A, Jiang MH, Ma KC, Nie JX, Olsson $\mathrm{Y}$, Sonrander P. Structural and vasonctive factors infuencing intracerebral arterioles in cases of vascular dementia and other cerebrowascular disease: a review. Immunohistochemical studies on expression of collagens, basal lamina components and endothelin-1. Dementia. 1994;5:153-162.

195. Zijlmans JC, De Koster A, Van 't Hof MA, Thijssen HO, Horstink MW, Heerschap A. 
Proton magnetic resonance spectroscopy in suspected vascular ischemic parkinsonism. Acta Netural Scand. 1994,90:405-411.

196. Zijlmans JCM, Thijssen HOM, Vogels OJM, Kremer HPH, Poels PJE, Schoonderwaldt HC, Merж JL, Van 't Hof MA, Thien T, Horstink MWIM. MRI in patients with suspected vascular parkmsonism. Neurology. 1995; $45: 2183-2188$.

197. Zimmerman RD, Fleming CA, Lee BC, Saint Louis LA, Deck MD. Periventricular hyperintensity as seen by magnetic resonance: prevalence and significance. AJNR. $1986 ; 7: 13-20$. 


\section{Publications}

- Van Zagten MSG, Troost J, Heeres JG.

Cervicale myelopathie als complicatie van manuele therapie bij een patiënt met een nauw cervicaal kanaal.

Ned Tijdschr Geneeskd. 1993;137:1617-1618.

- Van Zagten M, Lodder J, Franke C, Heuts-Van Raak L, Claassens C, Kessels F.

Different vascular risk factor profiles in primary intracerebral haemorrhage and small deep infarcts do not suggest similar types of underlying small vessel disease.

Cerebrovasc Dis. 1994;4:121-124.

- Van Zagten MSG, Lodder J, Kessels F.

Gait disorder and parkinsonian signs in stroke patients; associations with CT findings and vascular risk factors.

Cerebrovas Dis. 1996;6 (suppl 2):31 (Albstract).

- Van Zagten M, Boiten J, Kessels F, Lodder J.

Significant progression of white matter lesions and small deep (lacunar) infurcts in patients with stroke.

Arch Neurol. 1996;53:650-655.

- Van Zagten M, Lodder J, Kessels F.

Gait disorder and parkinsonian signs in patients with stroke relate to small deep infarcts and white matter lesions.

Mov Disord. In press. 


\section{Dankwoord}

De volgende mensen wil ik bedanken voor hun steun en bijdrage aan de totstandkoming van dit proefschrift:

- allereerst Jan Lodder en Jelis Boiten: zonder jullie zachte, maar besliste en onophoudelijke aandrang was dit boekje er zonder twijfel nooit gekomen. Ik ben soms door mijn eigen-wijsheid zeer lastig te sturen, maar jullie hebben het toch voor elkaar gekregen.

- mijn opleider en promotor Prof.dr. Jaap Troost: de samenwerking met jou is altijd inspirerend geweest. Bedankt voor al het vertrouwen dat je in mij gehad hebt.

- Fons Kessels wist mijn onnozelheid op epidemiologisch gebied om te vormen in enig begrip, onder het genot van diverse koppen koffie en lolly's.

- de patiënten voor deelname aan deze studie.

- Lisette Heuts-van Raak heeft mij wegwijs gemaakt in status- en archiefland, en was daarnaast een zeer welkome vraagbaak bij computer-problemen.

- Marjan van de Pol, mijn sportmaatje, voor de computerondersteuning, waaronder het perfectioneren van diverse figuren.

- de secretaresses en poli-dames van de neurologie voor alle hulp.

- I would like to thank Prof. S. Marinkovic for granting me permission to reproduce a photograph from one of his articles in chapter 1.

- en natuurlijk Maarten van wiens hand deze layout is: wat moeten we nu nog verder bereiken als koppel "doctors"? Gewoon heerlijk verder leven, denk ik. 


\section{Curriculum Vitae}

Marian wan Zagten werd geboren op 5 juni 1964 te Beek-Ubbergen. In 1982 deed ze eindexamen VWO aan het Canisius College-Mater Dei te Nijmegen. Hierna ging ze Geneeskunde studeren aan de Katholieke Universiteit Nijmegen. In 1984 combineerde ze dit, aanvankelijk zonder serieuze bedoelingen, met de bovenbouw-studie Wijsbegeerte, eveneens aan de KUN. In 1987 werd het Doctoraalexamen Geneeskunde behaald. De co-schappen werden nog even uitgesteld, zodat in 1989 het doctoraal Wijsbegeerte werd behaald in de richting Filosofie van de Geneeskunde met een afstudeerscriptie over de hersenanatoom/psychiater Theodor Meynert. De hierop volgende co-schappen werden afgesloten met het artsexamen in 1991. Ze ging meteen in de Neurologie ann de slag in Medisch Spectrum Twente, Enschede, bij (toen nog) Dr. J. Troost. In 1992 kwam ze in dienst van het Academisch Ziekenhuis Maastricht, alwaar met de opleiding Neurologie werd begonnen (opleider Prof.dr. J. Troost). Ze is nu met haar laatste stage bezig op de afdeling Klinische Neurofysiologie, bij Prof.dr. F. Spaans, en hoopt in augustus 1998 haar opleiding te voltooien. 